UNIVERSIDADE DE BRASÍLIA - UNB

FACULDADE DE ECONOMIA, ADMINISTRAÇÃO, CONTABILIDADE E CIÊNCIA DA INFORMAÇÃO E DOCUMENTAÇÃO - FACE

PATRÍCIA BARBOSA DE CASTRO

OS DOCUMENTOS DO SIAFI COMO FONTE DE INFORMAÇÕES GERENCIAIS

Brasília - DF 
PATRÍCIA BARBOSA DE CASTRO

\title{
OS DOCUMENTOS DO SIAFI COMO FONTE DE INFORMAÇÕES GERENCIAIS
}

\begin{abstract}
Monografia apresentada ao Programa de Pós-Graduação em Administração (PPGA) da Faculdade de Economia, Administração, Contabilidade e Ciência da Informação e Documentação (FACE), da Universidade de Brasília, como requisito parcial à obtenção do grau de Especialista em Orçamento e Finanças
\end{abstract}

Orientador: Gilvan da Silva Dantas

Brasília - DF 


\section{AGRADECIMENTOS}

Ao Carlos, pelo companheirismo, apoio, incentivo, carinho e presença constante em todos os momentos.

Ao meu irmão Ernane e à minha cunhada Waleska, pela torcida e pela amizade que nos une.

Aos meus pais, Francisco e Ângela, a quem devo todas as minhas conquistas.

À minha sogra D. Bebel, pela acolhida diária cheia de alegria.

Aos meus queridos Eduardo, Gabriel, André, Gustavo e Guilherme, pela compreensão e apoio nos meus momentos de estudo.

Aos meus amigos de trabalho do DW Pagamento Efetivo: Adriana, Mayra, Maciel, Sávio, CH e Fagner, pela dedicação, parceria e convívio alegre, e em especial ao Gilverlan, pela ajuda e revisão deste trabalho.

Ao meu orientador Gilvan, pelo incentivo para que eu escrevesse sobre este tema. 
"A mente que se abre a uma nova idéia jamais voltará ao seu tamanho original."

Albert Einstein 


\section{RESUMO}

O Sistema Integrado de Administração Financeira do Governo Federal (SIAFI) é a fonte de dados principal para a coleta de informações orçamentárias e financeiras do governo, porém sua arquitetura é voltada para o processamento de transações e não a produção de informações gerenciais. Em geral, para recuperação destas informações é necessário conhecimento da estrutura contábil e da lógica de seus lançamentos.

O presente trabalho realizou a análise do SIAFI como provedor de informações gerenciais, mas com foco em seus documentos e não em sua estrutura contábil. Um modelo conceitual de dados baseado na tecnologia data warehousing foi proposto, mas a maior contribuição deste trabalho é a análise das limitações existentes no SIAFI que possam impactar ou dificultar a extração e/ou a consolidação de informações gerenciais.

Palavras-chaves: Sistema de informações gerenciais, Data warehouse, SIAFI. 


\section{LISTA DE FIGURAS}

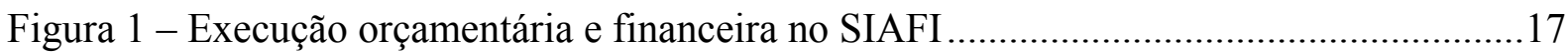

Figura 2 - Lançamento contábil no SIAFI ...................................................................19

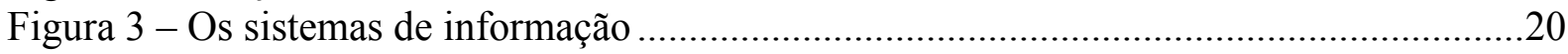

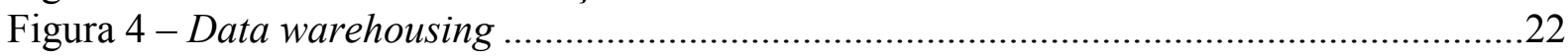

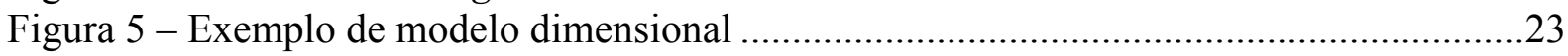

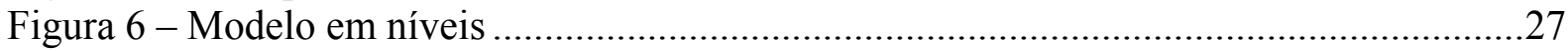

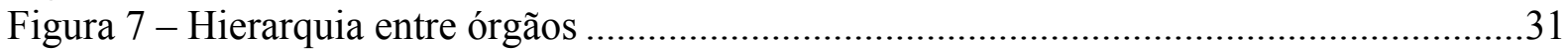

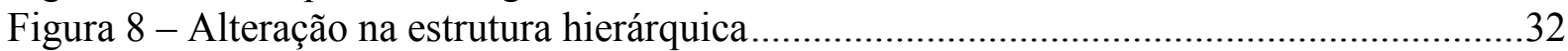

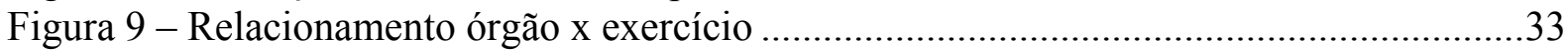

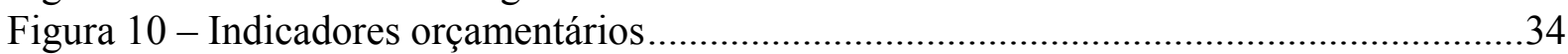

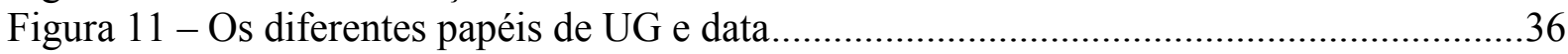

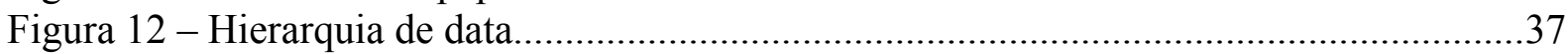

Figura 13 - Hierarquia empenho original e referência .......................................................43

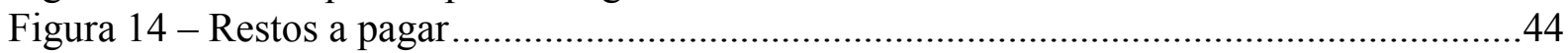

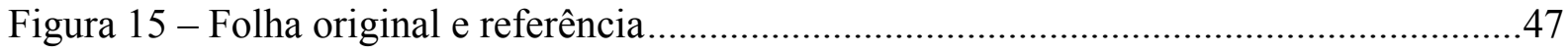

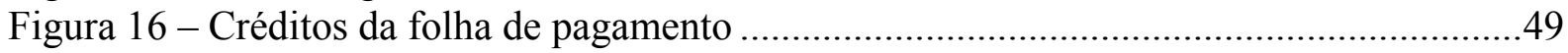

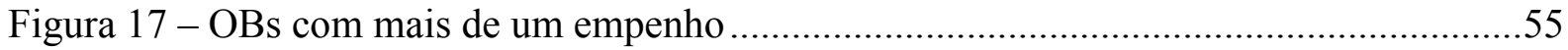

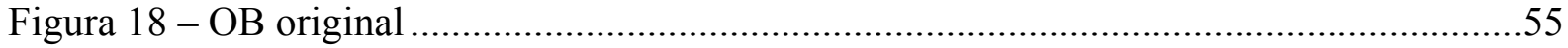

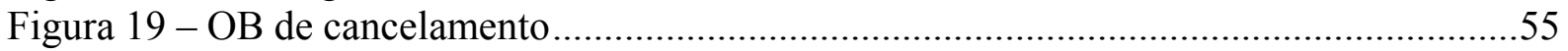

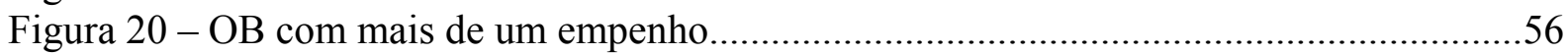

Figura 21 - Cruzamento de dados orçamentários e financeiros ............................................58

Figura 22 - Falta de cruzamento de dados orçamentários e financeiros ..................................58

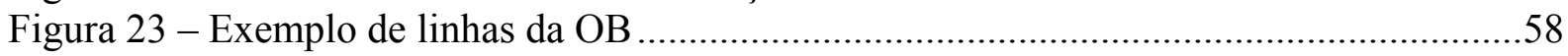

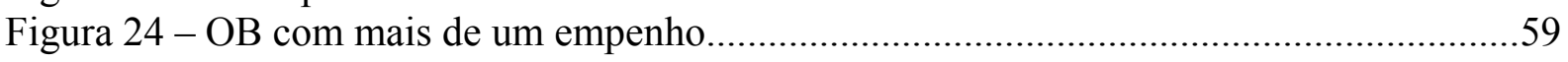

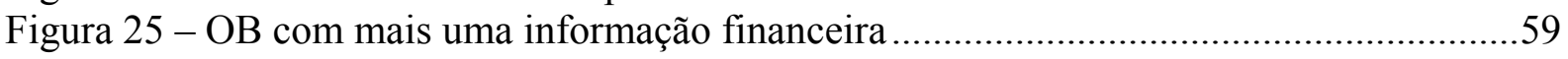

Figura 26 - OB com vários empenhos e vários dados financeiros ..........................................59

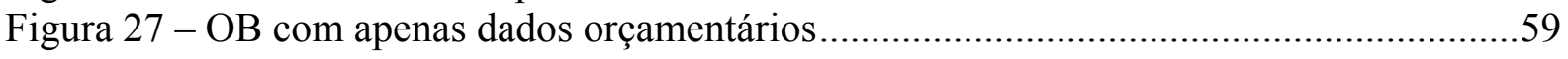

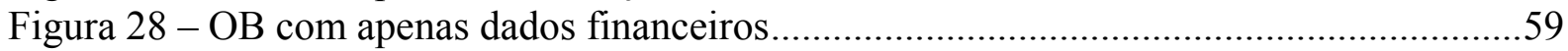

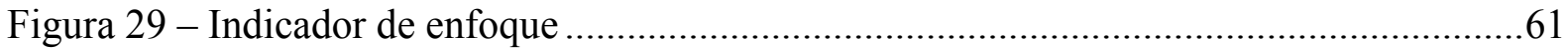

Figura 30 - Exemplo de consulta a ser respondida pelo modelo............................................64 


\section{LISTA DE QUADROS}

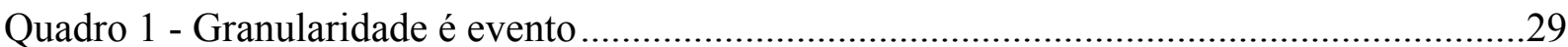

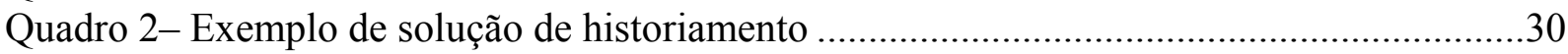

Quadro 3 - Hierarquia entre órgãos da Presidência da República..........................................31

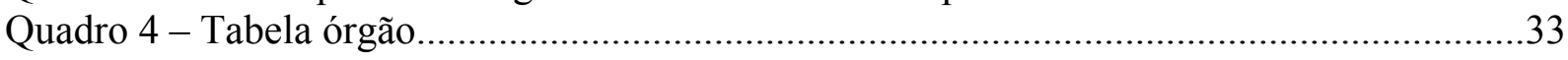

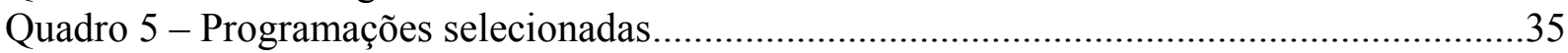

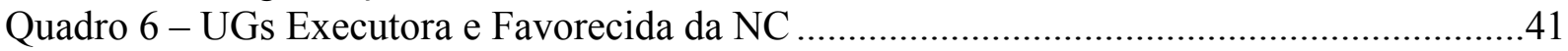

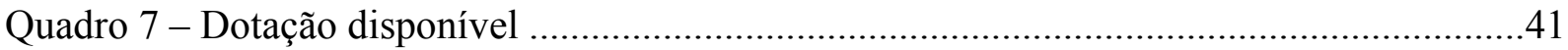

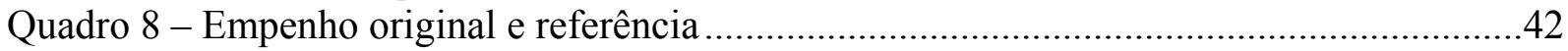

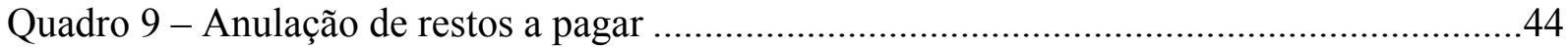

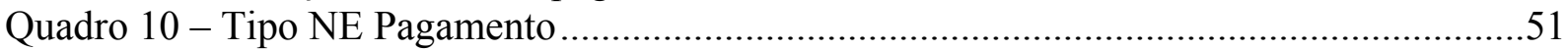

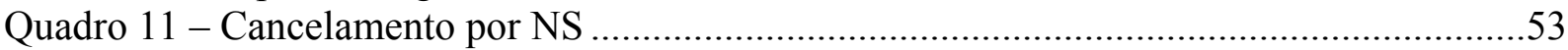

Quadro 12 - Carga de OB com mais de um empenho............................................................56 


\section{LISTA DE SIGLAS}

CPR Contas a Pagar e a Receber

DAR Documento de Arrecadação Municipal

DARF Documento de Arrecadação de Receitas Federais Eletrônico

DW Data warehouse

ETL Extract, Transform and Load

FE Documento de Estorno da Despesa Orcam. com Pessoal

FL Documento de Apropriação Folha de Pessoal

FO Folha de Pessoal - Pagamento por Outro Documento

FR Documento de Reclassifição da Despesa - Folha de Pessoal

GFIP Guia de Recolhimento do FGTS e informações à Previdência Social

GPS Guia da Previdência Social

GRU Guia de Recolhimento da União

LDO Lei de Diretrizes Orçamentárias

LOA Lei Orçamentária Anual

NC Nota de Movimentação de Crédito

ND Nota de Dotação

NE Nota de Empenho

NS Nota de Lançamento de Sistema

OB Ordem Bancária

OLAP On-line Analytical Processing

PAC Programa de Aceleração do Crescimento

PPA Plano Plurianual

PPI Projeto Piloto de Investimento

RP restos a pagar

SAD Sistemas de apoio à decisão

SI Sistemas de Informação

SIAFI Sistema Integrado de Administração Financeira do Governo Federal

SIASG Sistema Integrado de Administração de Serviços Gerais

SIE Sistemas de informações executivas

SIG Sistemas de informações gerenciais

SPT Sistema de Processamento de Transações

UG Unidade Gestora 


\section{SUMÁRIO}

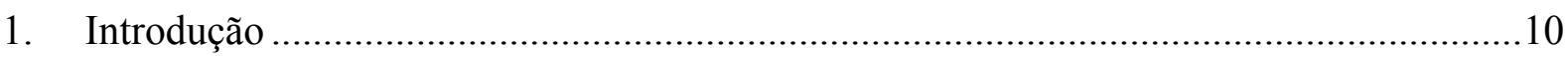

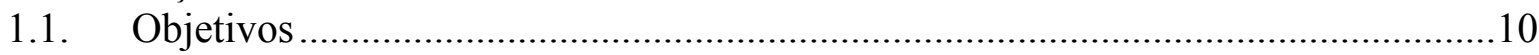

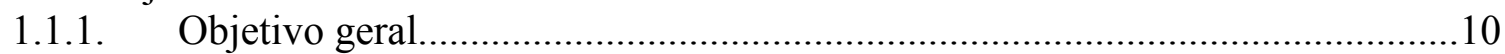

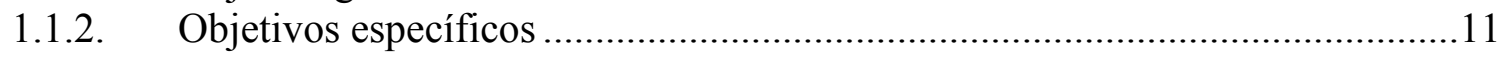

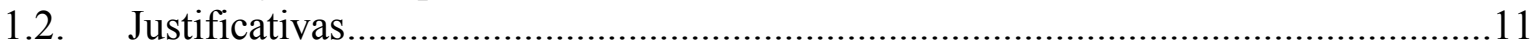

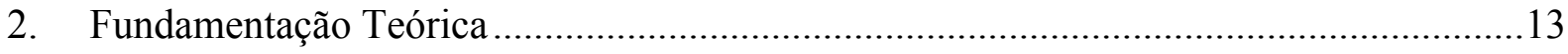

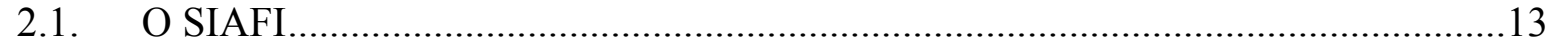

2.2. O SIAFI como fonte de dados para sistemas de suporte a decisão...........................14

2.3. Execução orçamentária e financeira da despesa pública no SIAFI .........................15

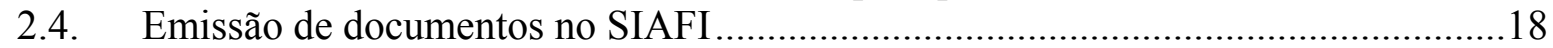

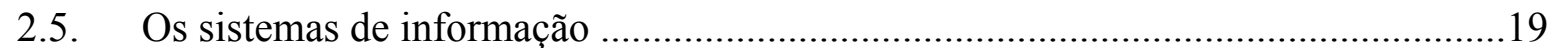

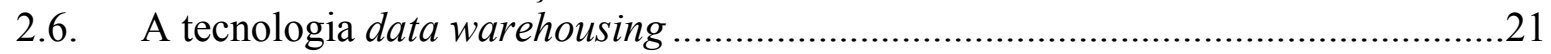

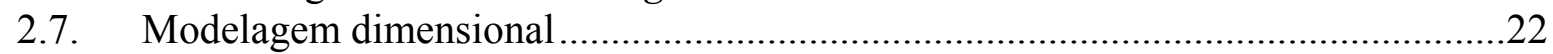

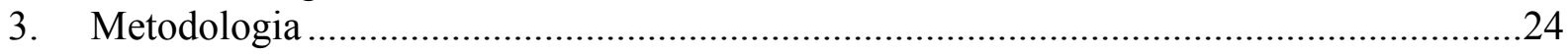

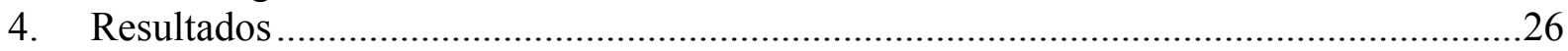

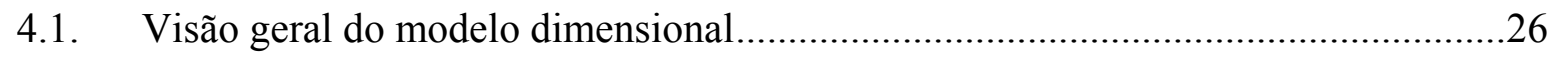

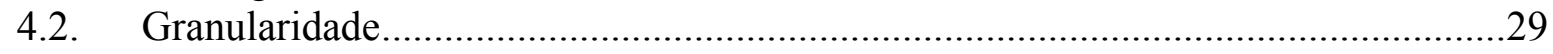

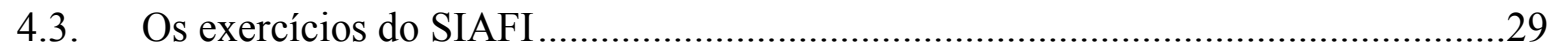

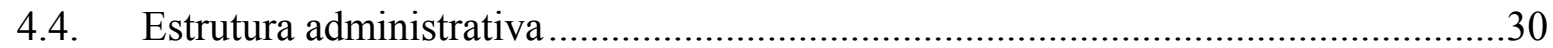

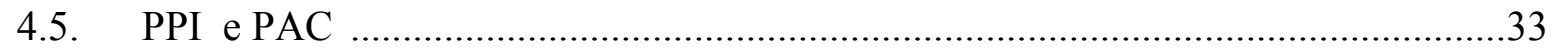

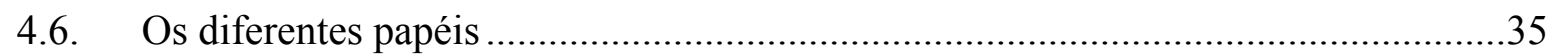

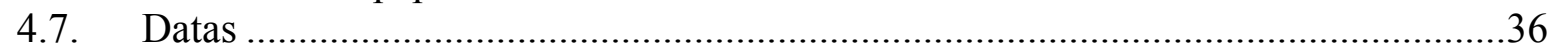

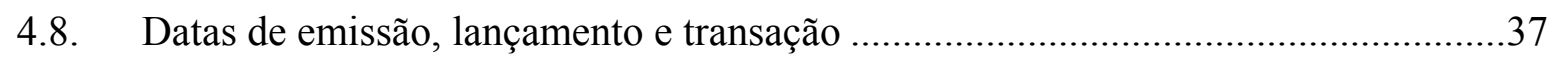

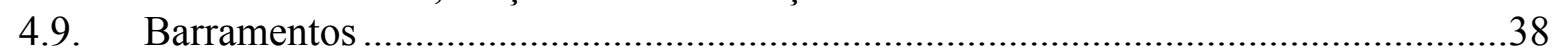

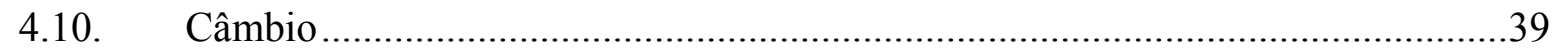

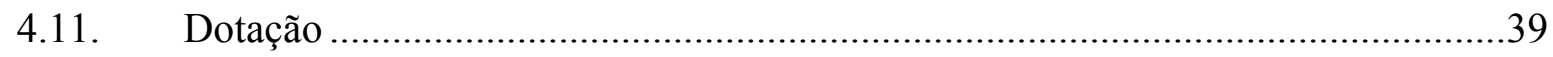

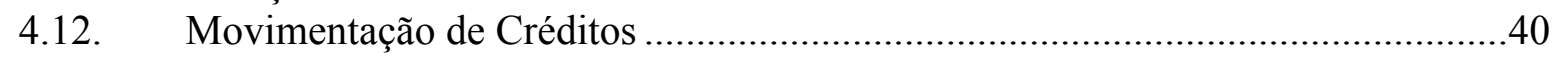

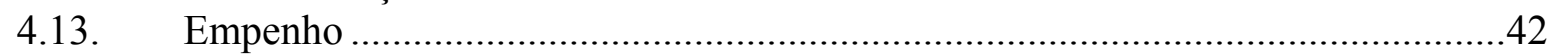

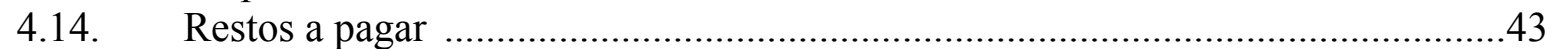

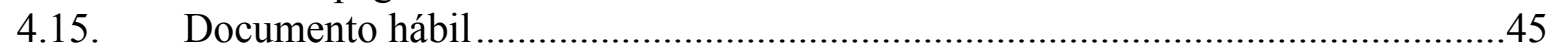

4.16. Folha de pagamento versus documento hábil .......................................................46

4.17. Folha de pagamento - FL versus FP..............................................................46

4.18. Folha de pagamento - estorno e reclassificação ...............................................47

4.19. Folha de pagamento - pagamento por FO .....................................................47

4.20. Folha de pagamento - documento de pagamento .............................................48

4.21. Folha de pagamento - créditos orçamentários ......................................................48

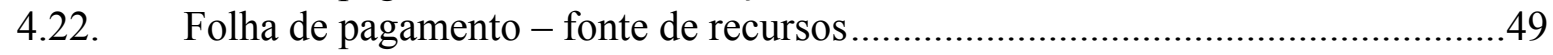

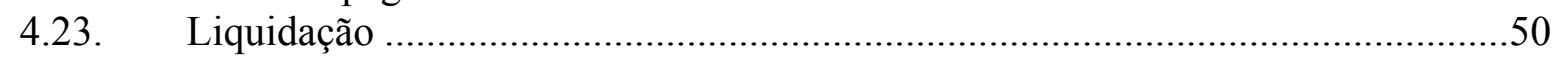

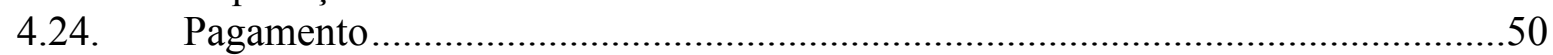

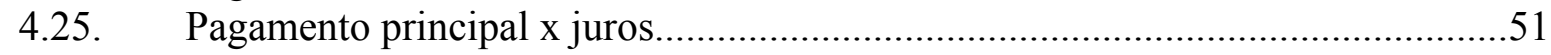

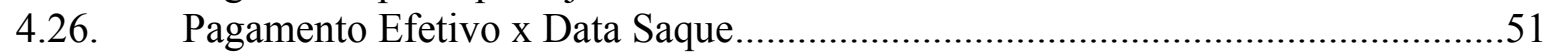

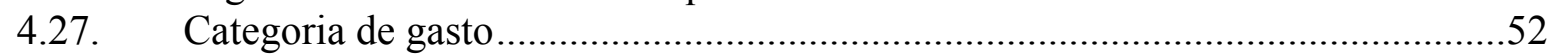

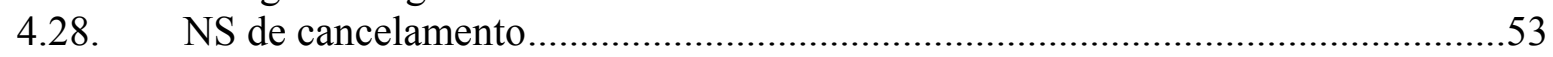

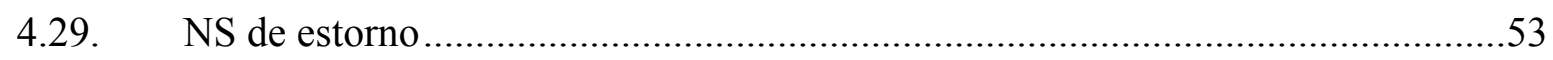

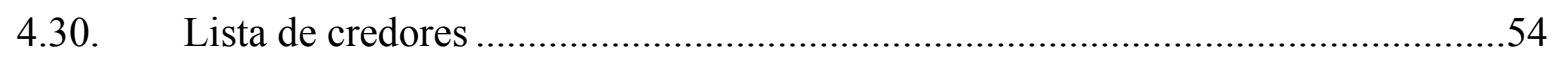

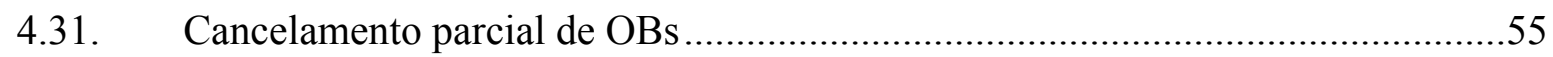

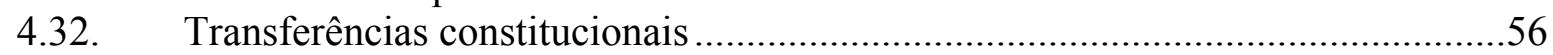

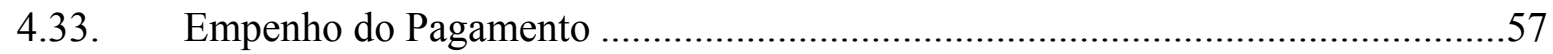




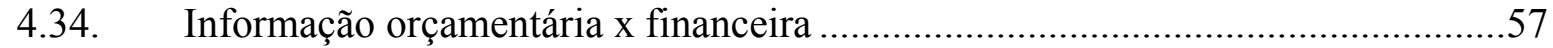

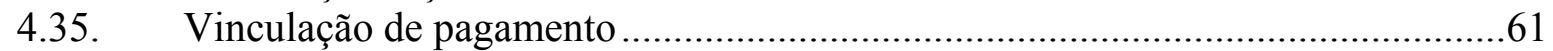

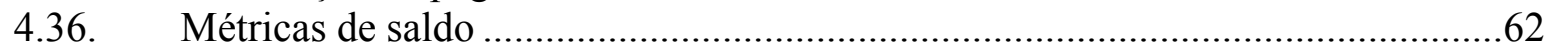

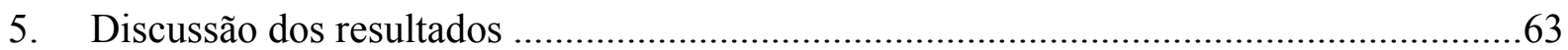

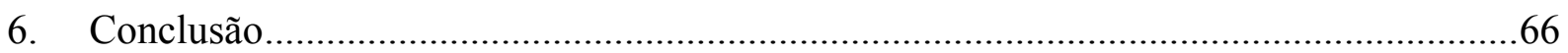

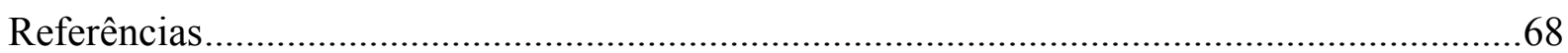

APÊNDICE A - Modelo dimensional - Contextos de análise............................................. 70

APÊNDICE B - Modelo dimensional - Descrição das métricas ...........................................79

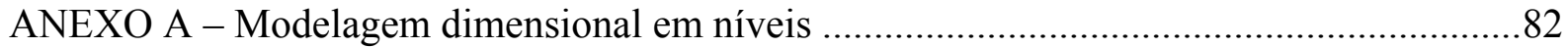




\section{INTRODUÇÃO}

A Administração Pública Federal necessita de informações gerenciais, seja para a tomada de decisão, seja por imposição legal, seja para a disponibilização de informações para a sociedade.

O Sistema Integrado de Administração Financeira do Governo Federal (SIAFI) é a fonte de dados principal para a coleta de informações orçamentárias e financeiras do governo, porém sua arquitetura é voltada para o processamento de transações e não a produção de informações gerenciais.

Em geral, os relatórios gerenciais são construídos com base em diversas planilhas eletrônicas, montadas a partir de coletas de dados do SIAFI e do SIAFI Gerencial onde são necessários conhecimentos da estrutura contábil e da lógica de seus lançamentos. Um grande esforço é despendido e os gestores gastam parte do seu tempo no levantamento e na organização dos dados quando poderiam ter as informações de forma mais rápida e concentrar-se na tomada de decisões.

Como alternativa, vários órgãos têm desenvolvido sistemas próprios, tendo a estrutura contábil do SIAFI como fonte de informações.

O presente trabalho, porém, pretende realizar a análise do SIAFI com foco em seus documentos e não em sua estrutura contábil.

\subsection{Objetivos}

\subsubsection{Objetivo geral}

Analisar as necessidades de informações gerenciais e propor uma solução que viabilize a construção de um sistema de apoio à decisão com foco no acompanhamento da execução orçamentária e financeira e baseado nos documentos do Sistema Integrado de Administração Financeira do Governo Federal (SIAFI). 


\subsubsection{Objetivos específicos}

Como objetivos específicos, pretende-se:

i. Levantar as necessidades de informações gerenciais para o acompanhamento da execução orçamentária e financeira do Governo Central;

ii. Efetuar análise dos documentos do SIAFI e seus procedimentos entrada de dados para identificar as informações constantes nos documentos, as informações em comum entre os documentos e as lacunas de informações existentes;

iii. Propor modelo conceitual de dados para o sistema de apoio à decisão;

iv. Identificar as limitações existentes no SIAFI que possam impactar ou dificultar a extração e/ou a consolidação das informações em um data warehouse;

v. Propor adequações na origem dos dados ou nos procedimentos, de forma a obter maiores benefícios da ferramenta de apoio à decisão.

\subsection{Justificativas}

Baseado na Contabilidade, o SIAFI está ancorado no tripé Plano de Contas, Conta Única do Tesouro Nacional e Tabela de Eventos. O Plano de Contas possui a estrutura da informação e a Tabela de Eventos é a base para os registros contábeis automáticos.

Como explicam Silva et al (2007), o SIAFI, apesar de complexo e da Contabilidade ser sua "alma", grande parte dos usuários não necessitam de muitos conhecimentos de contabilidade pública para a sua operação.

Mas, para a extração de informações gerenciais no sistema SIAFI são necessários conhecimentos da estrutura contábil e da lógica de seus lançamentos. Para a recuperação das informações o usuário necessita indicar a conta contábil, e o SIAFI, por ser um Sistema de Processamento de Transações (SPT), não possui as funcionalidades adequadas que permitam o tratamento e a navegação nestas informações de forma facilitada.

Para permitir uma melhor recuperação de informações gerenciais e de modo a minimizar a limitação de conhecimento das contas contábeis do Plano de Contas foi construído o sistema SIAFI Gerencial. Ainda assim, toda a estrutura de recuperação das informações é baseada nas contas contábeis e nos saldos dos lançamentos contábeis. 
O SIAFI é a principal fonte de informações para diversos outros sistemas de informações gerenciais tais como o Síntese, do Tribunal de Contas da União o Siga Brasil, do Senado Federal, o Portal da Transparência, da Controladoria Geral da União e o Contas Abertas, da organização da sociedade civil de mesmo nome. Analisando-se de forma superficial, acredita-se que a estrutura lógica destes sistemas seja baseada nas contas contábeis do SIAFI.

Porém, observando-se o projeto lógico do SIAFI verifica-se que uma vez que os lançamentos contábeis são gerados a partir do registro do fato contábil em um documento no sistema, estes documentos gerados pelo sistema podem ser uma rica fonte de dados para um sistema de informações gerenciais.

Os documentos de orçamento, de finanças e de contabilidade, conforme confirmam Castro e Garcia (2004), são a fonte analítica de dados e, portanto reúnem todas as informações dos fatos contábeis que originaram seu registro.

A STN, em 2007, iniciou o projeto DW Pagamento Efetivo com o objetivo de identificar os pagamentos efetuados pelos gestores públicos e a despesa orçamentária e extraorçamentária via conta única do Tesouro Nacional.

Este DW tem como base os documentos de pagamento do SIAFI e a sua respectiva integração com o empenho da despesa, e é, assim, o ponto de partida para uma visão gerencial do SIAFI sob outro aspecto: os documentos.

A partir da experiência adquirida com a $1^{\text {a }}$ versão do DW Pagamento Efetivo e com base nas dificuldades encontradas, pretende-se com este estudo propor um modelo de dados composto por documentos do SIAFI que possa responder as necessidades de informações gerenciais da execução orçamentária e financeira dos órgãos do governo federal. Pretende-se analisar o contexto atual da extração das informações gerenciais pela Secretaria do Tesouro Nacional e propor uma ferramenta de apoio à decisão que suporte a demanda atual de forma ágil, consistente e eficiente.

O referido modelo de dados será baseado na tecnologia denominada Data Warehousing e deverá pressupor a sua possível construção em ferramenta de processamento analítico da informação On-line Analytical Processing (OLAP), direcionada a usuários que não necessitam possuir conhecimentos técnicos ou detalhes do projeto de informação original (GONZAGA, 2005). 


\section{FUNDAMENTAÇÃO TEÓRICA}

\subsection{O SIAFI}

A Secretaria do Tesouro Nacional foi criada em 10 de março de 1986 e constitui-se órgão central do Sistema de Administração Financeira Federal e do Sistema de Contabilidade Federal. Sua criação foi um passo significativo no fortalecimento das finanças públicas no Brasil.

Esta centralização das atividades financeiras federais resultou em um marcante movimento de modernização e racionalização da administração pública brasileira, como a criação, em janeiro de 1987, do SIAFI.

O SIAFI é um sistema on-line que se constitui no principal instrumento de administração orçamentária e financeira da União, promovendo os órgãos centrais, setoriais e executores da gestão pública de mecanismos adequados à realização, ao acompanhamento e ao controle da execução orçamentária e financeira, tornando a contabilidade fonte segura de informações gerenciais. (GUIMARÃES, 2003)

Mas, conforme afirmam Silva et al. (2007), uma das limitações do SIAFI é a fraca interatividade com o usuário, uma vez que é um programa executado com a mesma tecnologia empregada quando da sua criação, em meados da década de 80, com o emprego de comandos codificados, que representam instruções reconhecidas pelo computador

Gonzaga (2005) atenta para que a existência da informação operacional não garante sua oferta de informação necessária à tomada de decisão gerencial. A extração e a interpretação de informações a serem utilizadas para o apoio gerencial dependem de recursos humanos especializados, e essa dependência dificulta o acesso às informações pelos tomadores de decisão e, no caso da Administração Pública, de usuários com interesse vertical, como por exemplo os cidadãos.

Com o objetivo de suprir esta lacuna gerencial do SIAFI, foi desenvolvido o SIAFI Gerencial para atender às demandas das áreas que possuem atribuições de gerência orçamentária, financeira e controle e subsidiar as áreas estratégicas de informações para o aperfeiçoamento do processo de tomada de decisões.

O SIAFI Gerencial é um sistema desenvolvido para plataforma Windows e possibilita a obtenção de informação a partir de consultas ad-hoc. Esse sistema não é utilizado como 
entrada de dados para a execução orçamentária ou financeira, pois destina-se à extração de informações. O banco de dados, que é extraído do SIAFI, é atualizado diariamente e possui sempre dados do movimento do dia anterior. Dessa forma, tornou-se possível consolidar diversas informações, pois o SIAFI só permite a consulta individualizada, de modo que uma consulta do SIAFI Gerencial corresponde a uma infinidade de consultas pelo sistema operacional.

Como observam Silva et al. (2007), no SIAFI Gerencial, também se pode realizar consultas aos documentos de uma mesma espécie emitidos em determinado exercício. A consulta é exportada para uma planilha eletrônica em cujo ambiente é possível a criação de gráficos e tabelas, bem como de todos os recursos que uma planilha eletrônica permite realizar. Cabe ressaltar que esta consulta aos documentos é desvinculada do saldo contábil e da execução orçamentária e financeira, e se propõe à análise dos documentos emitidos, de forma estanque.

Considerando que este sistema utiliza um grandioso banco de dados à disposição dos administradores públicos, Bastos et al. (2004) afirmaram que ele possui características de um sistema Data Warehouse.

Mas o SIAFI Gerencial, considerado muito avançado na época de sua concepção, continua com a mesma plataforma tecnológica. Possui limitações de instalação, de interface com o usuário e carece das facilidades que hoje estão disponíveis nos sistemas de apoio à decisão.

\subsection{O SIAFI como fonte de dados para sistemas de suporte a decisão}

De acordo com Silva et al. (2007), a Função de Controle da Administração Pública está estreitamente relacionada com a Contabilidade Governamental. Conforme prescreve o Decreto-Lei no 200, de 1967, no seu art. 83, a função primordial da contabilidade pública é prover a evidenciação das informações relativas ao controle do patrimônio público.

Em 2000, a Lei de Responsabilidade Fiscal (LRF) ou Lei Complementar $n^{0} 101$, de 04 de maio, estabeleceu normas de finanças públicas voltadas para a responsabilidade na gestão fiscal. (BRASIL,2000)

A contabilidade e a divulgação das informações serão fatores essenciais para garantir a transparência dos atos e fatos, como cita nos artigos 50 a 55, que dispõem, no seu conjunto, 
sobre a escrituração contábil, consolidação das contas das esferas de governo e sobre elaboração de relatórios da execução orçamentária e de gestão fiscal. (Guimarães, 2003)

O SIAFI é, portanto, no Governo Federal, a fonte de dados destas informações. Mas devido à carência de ferramentas flexíveis de acesso aos dados, seja no SIAFI, seja no SIAFI Gerencial, vários órgãos têm desenvolvido seus próprios sistemas de apoio à decisão.

O Senado Federal implantou um sistema de consulta aos dados orçamentários denominado Siga Brasil (www.senado.gov.br), que se encontra disponível com livre acesso por meio da internet. Como explicam Bastos et al. (2004), o Sistema de Informações Orçamentais Gerenciais Avançadas (SIGA) tem por objetivo a análise do orçamento da União. Compõe-se de três partes distintas e complementares, a saber: um eficiente Data Warehouse (DW), um portal de pesquisas e uma poderosa ferramenta de pesquisa e análise.

O Tribunal de Contas da União (TCU) construiu o Sistema de Inteligência e Suporte ao Controle Externo (SINTESE), baseado em tecnologia de Data Warehousing que integra dados de diversos sistemas da Administração Pública, tais como SIAFI, Sistema Integrado de Administração de Serviços Gerais (SIASG), Sistema Integrado de Administração de Recursos Humanos (SIAPE), dentre outros sistemas internos do TCU.

Já o Portal da Transparência (http://www.portaltransparencia.gov.br), da CGU, e o Contas Abertas (http://contasabertas.uol.com.br), são sítios que possuem consultas semiestruturadas e podem ser classificados como sistemas de informações gerenciais.

Analisando-se estes sistemas verifica-se que suas bases de dados são os lançamentos contábeis do SIAFI.

\subsection{Execução orçamentária e financeira da despesa pública no SIAFI}

A despesa pública se aplica à utilização dos recursos do Estado no custeio das atividades por ele desenvolvidas, seja na manutenção de suas instalações e equipamentos, seja na prestação de serviços para a sociedade ou na realização de investimentos e outros gastos voltados para o desenvolvimento da economia. (ALBUQUERQUE et al., 2008).

A despesa deve fazer parte de um programa no Plano Plurianual (PPA) e estar de acordo com a Lei de Diretrizes Orçamentárias (LDO) e seus anexos. 
A execução da despesa se inicia com a fase de previsão orçamentária, onde o planejamento das ações governamentais é realizado e publicado na Lei Orçamentária Anual (LOA).

Conforme explicam Valente e Dumont (2003), a LOA, depois de aprovada pelo Legislativo e sancionada pelo Executivo, deve ser detalhada e lançada no SIAFI e a partir daí, as unidades orçamentárias podem movimentar seus créditos que lhe foram designados. Esta fase é chamada de descentralização e movimentação dos créditos. Os documentos utilizados no SIAFI são a Nota de Dotação, que registra os créditos iniciais, e a Nota de Movimentação de Crédito.

A execução da despesa, a seguir, se faz em três fases: o empenho, a liquidação e o pagamento. O empenho e a liquidação dizem respeito ao processo orçamentário e o pagamento, ao processo de execução financeira.

O empenho representa o comprometimento, por parte da Administração, da utilização do crédito orçamentário. No SIAFI a Nota de Empenho é o documento que registra esta fase. Com a implantação do novo Documento Folha, este também passou a realizar os procedimentos da fase de empenho.

Já na liquidação ocorre a verificação do direito adquirido pelo credor, tendo por base os títulos e os documentos comprobatórios do respectivo crédito. O Contas a Pagar e a Receber (CPR) é o subsistema do SIAFI que a partir do registro de um Documento Hábil gera automaticamente os compromissos a pagar emitido as respectivas Notas de Lançamento de Sistema (NS) correspondente à fase da liquidação.

Por fim, o pagamento consiste no crédito de pagamento na conta do credor, que no SIAFI pode ser realizado pelos documentos Ordem Bancária (OB), Documento de Arrecadação Municipal (DAR), Documento de Arrecadação de Receitas Federais Eletrônico (DARF), Guia da Previdência Social (GPS), Guia de Recolhimento da União (GRU) e Guia de Recolhimento do FGTS e informações à Previdência Social (GFIP), a depender do tipo do credor.

A Figura 1 mostra as fases de execução da despesa e sua operacionalização no SIAFI através de documentos específicos. 


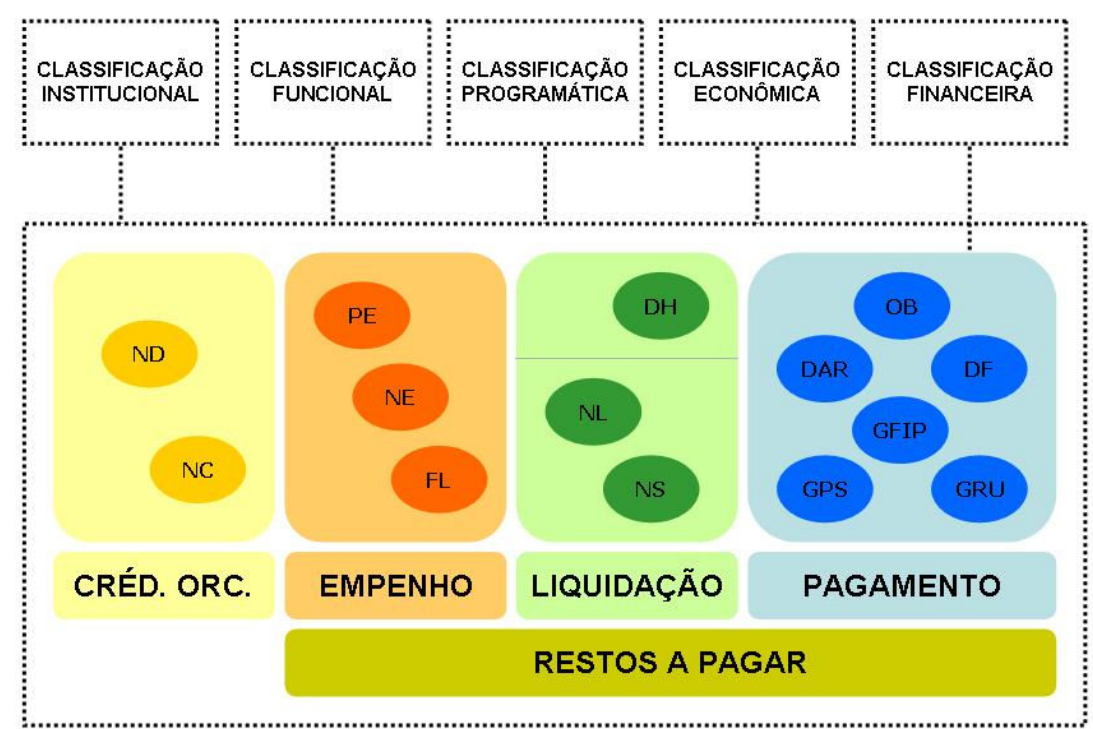

Figura 1 - Execução orçamentária e financeira no SIAFI

Aos documentos do SIAFI, juntam-se as diversas classificações que permitem identificar e detalhar a execução orçamentária e financeira. As classificações institucional, funcional, programática e econômica são orçamentárias. A classificação financeira é específica do fluxo de caixa e, portanto está presente apenas nos pagamentos.

A classificação institucional compreende os Órgãos da Administração Pública e suas respectivas Unidades Orçamentárias e identifica a estrutura administrativa responsável pela execução do orçamento.

A classificação funcional identifica a área de ação governamental em que a despesa será realizada e é representada por Função e Subfunção. A Função é o maior nível de agregação da despesa, detalhada através da Subfunção.

A classificação programática corresponde à finalidade dos recursos alocados e é detalhada por Programa, Ação e Localizador de Gasto. Programa é o instrumento de organização da ação governamental que articula um conjunto de ações visando à concretização do objetivo nele estabelecido (PPA 2008-2011,2009).

A Ação é a operação da qual resulta um produto ofertado à sociedade ou que contribui para atender ao objetivo de um programa. Pode ser orçamentária ou não orçamentária. Uma ação orçamentária demanda recursos orçamentários e pode ser um projeto, uma atividade ou uma operação especial. Um projeto é limitado no tempo e atua na expansão ou aperfeiçoamento das ações governamentais. Uma atividade é contínua e permanente e presta- 
se a manutenção das ações de Governo. As operações especiais não contribuem para a expansão ou aperfeiçoamento nem para a manutenção das ações. Por não demandarem recursos orçamentários, financiamentos, parcerias, plano de dispêndio das estatais e renúncia fiscal são ações não-orçamentárias. (ALBUQUERQUE et al., 2008).

Já a classificação econômica é classificação por natureza da despesa, que identifica o que está sendo adquirido e qual o efeito econômico da realização da despesa. A Categoria Econômica determina se a despesa é Corrente ou de Capital. O Grupo de Despesa classifica as despesas correntes em Pessoal e Encargos Sociais, Juros e Encargos da Dívida e Outras Despesas Correntes e as despesas de Capital em Investimentos, Inversões Financeiras e Amortização da Dívida. A indicação de onde os recursos serão aplicados é dada pela Modalidade de Aplicação, que pode ser mediante transferência financeira ou diretamente pela unidade detentora do crédito. Por fim, o Elemento de Despesa classifica de forma detalhada os bens ou serviços adquiridos.

Existem ainda outras classificações da despesa como a Esfera Orçamentária, a Fonte de Recursos e a série de Indicadores Orçamentários.

A Esfera Orçamentária identifica tipo de Orçamento, que pode ser Fiscal, da Seguridade Social ou de Investimento.

A Fonte de Recursos é o elemento que associa a classificação de receita com a classificação da despesa e permite o acompanhamento do cumprimento das vinculações constitucionais e legais estabelecidas.

Os Indicadores Orçamentários realizam o acompanhamento da gestão orçamentária do Governo. Um dos principais indicadores, por exemplo, é o de Resultado Primário, cuja finalidade é auxiliar na apuração do resultado primário previsto na LOA.

\subsection{Emissão de documentos no SIAFI}

Os lançamentos contábeis são gerados automaticamente a partir dos documentos, que são as entradas de dados do SIAFI, e da tabela de eventos. Os eventos transformam os atos e fatos administrativos rotineiros em registros contábeis automáticos. Nos eventos no SIAFI estão programadas as contas contábeis e os conta correntes que devem registrar, juntamente com o documento, o lançamento contábil, como ilustrado na Figura 2. 
Uma conta contábil permite identificar, classificar e efetuar a escrituração contábil. São estruturadas por níveis de desdobramento, classificadas e codificadas de modo a facilitar o conhecimento e a análise da situação orçamentária, financeira e patrimonial.

Já o conta corrente representa o menor nível de desdobramento da estrutura de uma conta contábil, permitindo o controle individualizado de saldos. Identificam, por exemplo, fornecedores, empenhos, transferências, célula orçamentária, entre outros.

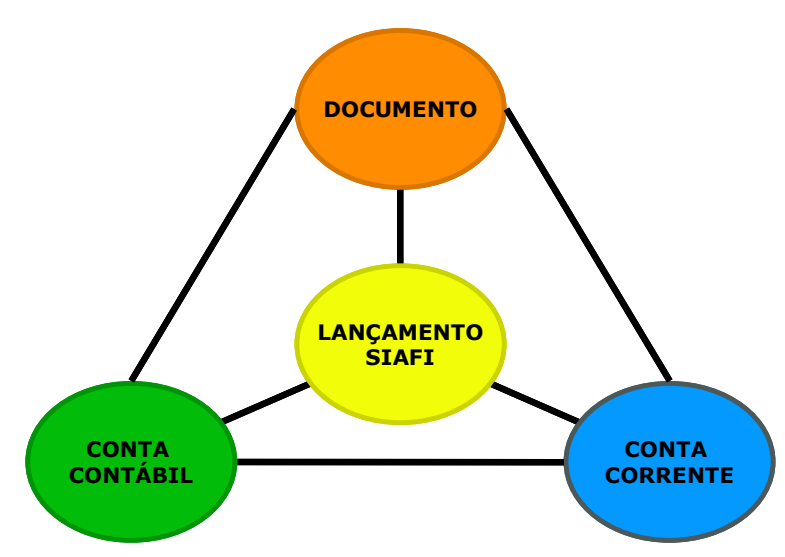

Figura 2 - Lançamento contábil no SIAFI

Silva et al. (2007) ressaltam que não é possível aos operadores a realização de nenhum lançamento diretamente nas contas contábeis, somente sendo possível a emissão de documentos, nos quais são inseridos os códigos de eventos.

As entradas de dados geram lançamentos contábeis e a contabilidade é o coração do SIAFI.

Por meio dos saldos das contas, é que são controladas as operações, como os limites de crédito orçamentário disponível para a emissão de empenhos e realização das despesas públicas e os limites de disponibilidades financeiras do exercício, assim como os saldos das contas patrimoniais. (SILVA et al., 2007).

\subsection{Os sistemas de informação}

Os Sistemas de Informação (SI) são sistemas que permitem a coleta, o armazenamento, o processamento, a recuperação e a disseminação de informações para dar 
suporte à decisão, através da coordenação, controle, análise e visualização de uma organização. (O’BRIEN, 2004).

O grau de dependência em relação aos SIs, conforme explicam Souza e Passalongo (2005), é cada vez maior em todos os tipos e tamanhos de empresas e em todos os setores da economia.

Analisando-se os trabalhos de Souza e Passalongo (2005), Rezende e Guagliardi (2005), Manfrinato (2002) e Gonzaga (2005), podemos encontrar uma classificação comum para os SIs.

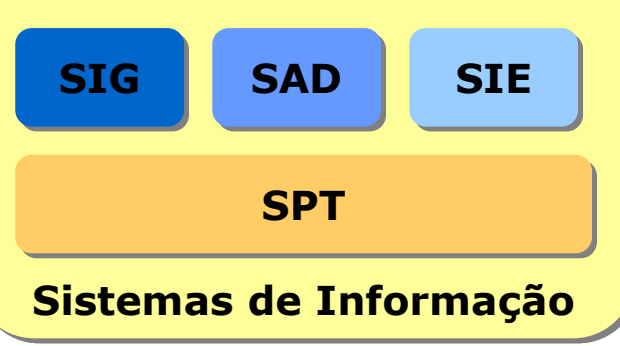

Figura 3 - Os sistemas de informação

Um Sistema de processamento de transações (SPT) realiza o processamento de operações rotineiras, incluindo seus respectivos procedimentos. Um SPT registra e armazena os dados que serão utilizados pelos demais tipos de SIs.

Os Sistemas de informações gerenciais (SIG) transformam as informações sobre transações dos SPTs em informações de uso da gerência da organização. Tipicamente fornecem relatórios pré-programados e seu foco é na eficiência operacional.

Já o foco dos Sistemas de apoio à decisão (SAD) é eficácia da tomada de decisão. Um SAD geralmente é utilizado quando o problema a ser solucionado é complexo ou quando a informação necessária para a tomada de decisão é de difícil obtenção. Segundo Manfrinato (2002), enquanto um SIG ajuda a "fazer as coisas direito", um SAD ajuda a "fazer a coisa certa".

Os Sistemas de informações executivas (SIE) processam grupo de dados das atividades operacionais transformando-as em informações estratégicas. Oferecem informações de forma simples, amigável (geralmente gráficos) e de acesso rápido.

O SIAFI Operacional, de acordo com essa classificação, é um sistema de processamento de transações. Já o SIAFI Gerencial é um sistema de apoio à decisão. 
O foco deste trabalho é construir um modelo dimensional que seja a base para a construção de um sistema de informações gerenciais.

\subsection{A tecnologia data warehousing}

A tecnologia de data warehousing (DW) surgiu na área de informática como uma evolução dos Sistemas de Suporte à Decisão.

Nóbrega (1999) afirma que data warehousing é a forma definitiva de se obter informação a partir das imensas quantidades de dados que vão sendo amontoados nos arquivos magnéticos pelo processamento de dados convencional. O data warehousing captura os dados nas bases de dados tradicionais, alimentadas pelos sistemas transacionais, lhes confere a contextualização do negócio e os disponibiliza, como informação, em uma base de dados com características peculiares.

O DW proporciona uma sólida e concisa integração de dados da organização para a realização de análises gerenciais estratégicas. Ele se preocupa em integrar e consolidar as informações, sumariando, filtrando, limpando e armazenando esses dados num repositório único para que estejam preparados para análise e suporte aos processos decisórios. (MACHADO, 2000).

Ainda segundo Nóbrega (1999), processar dados continua sendo a missão do processamento transacional. Processar informações para apoiar o processo decisório é a missão do data warehousing.

Bastos et al. (2004) completam que o maior objetivo de um DW é fornecer informações sobre um determinado assunto com precisão e rapidez, a qualquer usuário, sem a necessidade de conhecimento técnico de banco de dados. Tecnicamente, é povoado por um enorme volume de informações em um gigantesco, mas rápido, banco de dados.

É importante ressaltar que o DW é uma fonte secundária de informações povoada por bases de sistemas já existentes, tantos internos a organização, quantos externos. Em suma, é uma base tipicamente de leitura, desenhada exclusivamente para propósitos de análise.

A tecnologia DW compreende um processo que vai desde a extração de dados dos sistemas fonte até a disponibilização da solução ao usuário. A Figura 4 ilustra como os dados oriundos de diversos sistemas são disponibilizados aos usuários finais. 

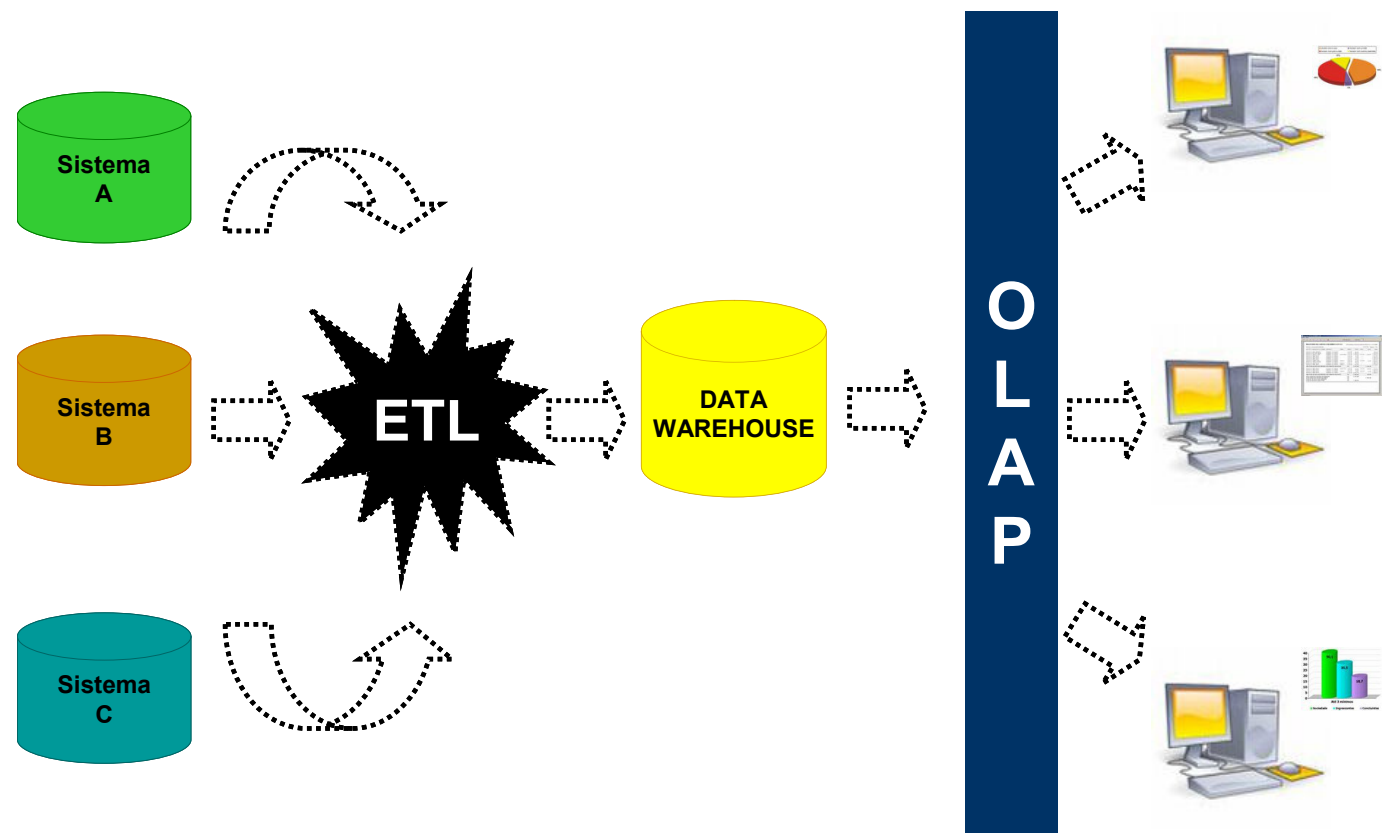

Figura 4 - Data warehousing

O processo de extração, transformação e carga de dados dos sistemas fonte para o DW é chamado "ETL" (do inglês "Extract, Transform and Load"). Este procedimento visa uniformizar a representação da informação, fazer o mapeamento dos dados e das regras que os acompanham, garantindo, desse modo, a consistência. (BASTOS et al., 2004)

Como resultado do processo de ETL tem-se a base de dados, chamada data warehouse. Rabello (2006) explica que o processo de análise de dados para geração de informação é feito por meio das ferramentas On Line Analytical Processing (OLAP). Neste processo pode-se pensar no DW como um cubo multidimensional, cada uma das arestas representando as dimensões de análise, cada uma das faces representando os cruzamentos das dimensões de análise. As ferramentas OLAP são capazes de navegar neste cubo, mostrando faces específicas, guiadas pelo usuário.

\subsection{Modelagem dimensional}

Mas, de acordo com Nóbrega (1999), a integração de dados não acontece por acaso, ela precisa ser construída, muitas vezes arduamente. Construir a integração constitui uma competência essencial na obtenção de informações úteis para a tomada de decisão.

A modelagem dimensional é uma técnica de concepção e visualização de um modelo de dados que descreve aspectos comuns de negócios, sendo empregada especialmente para 
reestruturar dados e apresentá-los em visões que suportem análises gerenciais (MACHADO, 2000).

A modelagem dimensional representará a visão do usuário sobre os dados e as diversas possibilidades de cruzamentos.

Utilizamos neste trabalho uma metodologia denominada "Modelagem Dimensional em Níveis", desenvolvida por Rosângela Nóbrega e aplicada em projetos de data warehousing do SERPRO. No Anexo A consta o resumo desta metodologia e a definição dos principais itens que a compõem.

Chamaremos de contexto de análise, cada tema que dará origem a uma tabela fato (ou estrela), conforme será visto em 4.1 Visão geral do modelo dimensional.

A cada parâmetro de pesquisa que estará disponível ao usuário chamaremos de atributos, e ao conjunto de atributos que possuem uma hierarquia entre si chamaremos de dimensão, conforme exibido na Figura 5.

A métricas definem os valores que poderão sofrer operações aritméticas para retornar informações consolidadas.

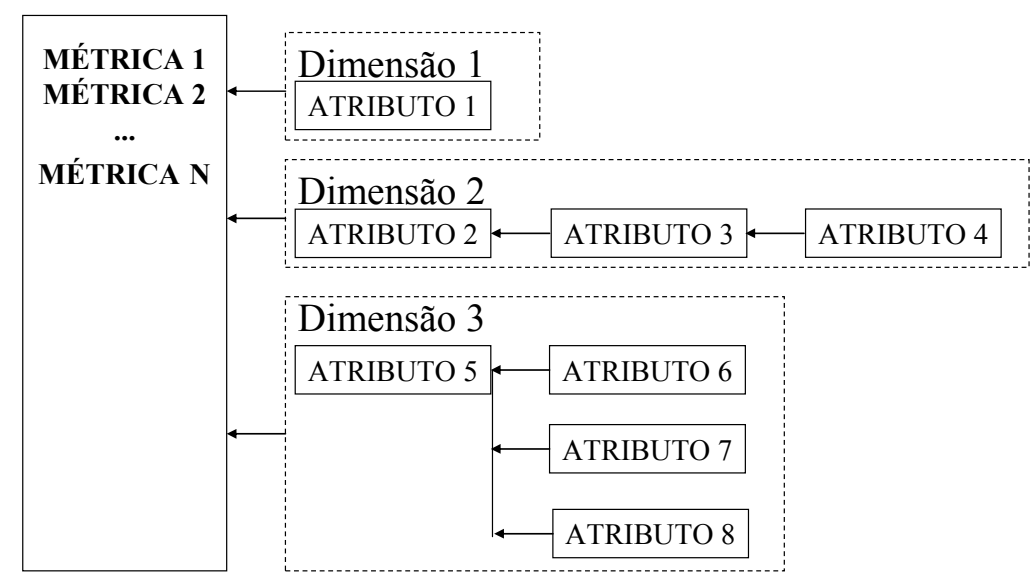

Figura 5 - Exemplo de modelo dimensional 


\section{METODOLOGIA}

A presente pesquisa foi desenvolvida na forma aplicada e qualitativa.

Foi aplicada, pois objetivou gerar conhecimento para aplicação prática dirigida à solução de problemas específicos. Foi qualitativa porque, como explica Godoy (1995), o pesquisador usou sua própria pessoa como instrumento mais confiável de observação, seleção, análise e interpretação dos dados coletados.

Quanto aos meios, fez uso de pesquisa bibliográfica e documental.

A pesquisa bibliográfica foi complementada com informações obtidas no Manual SIAFI, em consultas realizadas diretamente nos sistemas SIAFI, SIAFI Gerencial e DW Pagamento Efetivo, bem como nos sítios oficiais do Governo Federal.

A pesquisa documental teve como base os documentos do SIAFI que deram origem ao modelo dimensional proposto. Foram analisados os documentos:

- NOTA DE DOTACAO (ND): Permite registrar valores decorrentes de desdobramento, por Plano Interno e/ou por Fonte de Recursos (quando detalhada), dos créditos previstos no OGU, bem como a inclusão dos créditos nele não consignados.

- NOTA DE MOVIMENTACAO DE CREDITO (NC): Permite registrar a movimentação de créditos interna e externa e suas anulações.

- NOTA DE EMPENHO (NE): Permite registrar o comprometimento de despesa, bem como aos casos em que se faça necessário o reforço ou a anulação desse compromisso.

- FOLHA DE PAGAMENTO (FL): documento de execução orçamentária e financeira da folha de pagamento de pessoal.

- DOCUMENTO HÁBIL (DH): São os documentos cadastrados no Subsistema do SIAFI Contas a Pagar e a Receber (CPR), tais como contratos, notas fiscais, recibos, autorizações de viagem, etc. Estes documentos geram compromissos de pagamento ou de recebimento, que irão compor o fluxo de caixa montado pelo sistema.

- NOTA DE LANCAMENTO POR EVENTO (NL): Permite registrar eventos contábeis não vinculados a documentos específicos.

- NOTA DE LANCAMENTO DE SISTEMA (NS): Permite registrar eventos contábeis de forma automática. Realiza a incorporação, a transferência a extinção 
de saldos por meio da transação NSSALDO, efetua acertos contábeis, na ausência de eventos específicos por meio da transação NSCCONT e ainda permite a integração de saldos de Balanço ao SIAFI.

- ORDEM BANCÁRIA (OB): Permite registrar o pagamento de compromissos, bem como a transferência de recursos entre UG, liberação de recursos para fins de adiantamento, suprimento de fundos, cota, repasse, sub-repasse e afins.

- DOCUMENTO DE ARRECADACAO MUNICIPAL (DAR) - Permite registro da arrecadação de receitas de tributos e contribuições estaduais e municipais efetivadas pelos órgãos e Entidades públicas por meio de transferências de recursos INTRA-SIAFI entre a UG recolhedora e a Conta Única do Tesouro Nacional.

- DOCUMENTO DE ARRECADAÇÃO DE RECEITAS FEDERAIS ELETRONICO (DARF): Permite registrar a arrecadação de receitas federais efetivadas pelos Órgãos e Entidades, por meio de transferências de recursos intraSiafi entre a UG recolhedora e a Conta Única do Tesouro Nacional.

- GPS ELETRONICA (GPS): Permite registrar o recolhimento das contribuições para a Seguridade Social por meio de transferências de recursos intra-Siafi entre a UG recolhedora e a Conta Única do Tesouro Nacional.

- GUIA DE RECOLHIMENTO DA UNIAO (GRU) Eletrônica: Permite recolhimento de receitas da União de uma UG para outra UG via SIAFI.

- guia de RECOLHIMENTO DO FGTS (FUNDO DE GARANTIA) E INFORMAÇÕES À PREVIDÊNCIA SOCIAL (GFIP): Permite recolhimento de contribuições e/ou informações à Previdência Social via SIAFI.

Também foram analisados manuais de procedimentos e normas governamentais que suportam o assunto em questão.

Foram obtidas informações diretamente na Secretaria do Tesouro Nacional, que é o órgão gestor do SIAFI e no Serviço Federal de Processamento de Dados, desenvolvedor e provedor da solução tecnológica. 


\section{RESULTADOS}

\subsection{Visão geral do modelo dimensional}

O presente trabalho propõe um modelo de dados dimensional que permite recuperar informações das dotações e seus respectivos créditos orçamentários, dos empenhos, das liquidações e pagamentos efetuados no SIAFI, permitindo ainda, o cruzamento destas informações de forma flexível e o detalhamento destas até o nível do documento.

O cruzamento de informações é feito a partir das informações orçamentárias, permitindo a navegabilidade entre os contextos até se chegar ao pagamento e obter as informações financeiras.

A Figura 6 mostra o modelo em níveis dos contextos de análise. Cada estrela é um contexto de análise, que corresponde, neste caso, aos tipos de documento. Todas as informações referentes a cada documento estão detalhadas nos modelos dimensionais listados no Apêndice A.

De forma macro, os contextos de análise podem ser agrupados nos temas: Crédito Disponível, Empenho, Contas a Pagar, Liquidação e Pagamento.

O crédito disponível é a importância consignada no orçamento ou em crédito adicional para atender as despesas do governo, que no SIAFI são registrados respectivamente pelos documentos Nota de Dotação e Movimentação de Crédito.

O Empenho é o ato emanado de autoridade competente, que cria para o Estado obrigação de pagamento pendente ou não de implemento de condição. Representa uma reserva de recursos orçamentários para atender às despesas orçadas. A Nota de Empenho é o documento que registra este ato no SIAFI. Em complementação à Nota de Empenho, tem-se a lista de itens de Empenho que registra individualmente cada item empenhado (MANUAL SIAFI, 2009).

Em 2008, o SIAFI implantou o Documento Folha de Pagamento com o objetivo de automatizar o processo de execução orçamentária da folha de pagamento, e criou procedimentos próprios, inclusive realizando o procedimento do empenho sem utilizar a Nota de Empenho para tal. Por isso, então, considerou-se o Documento Folha de Pagamento no tema empenho. 


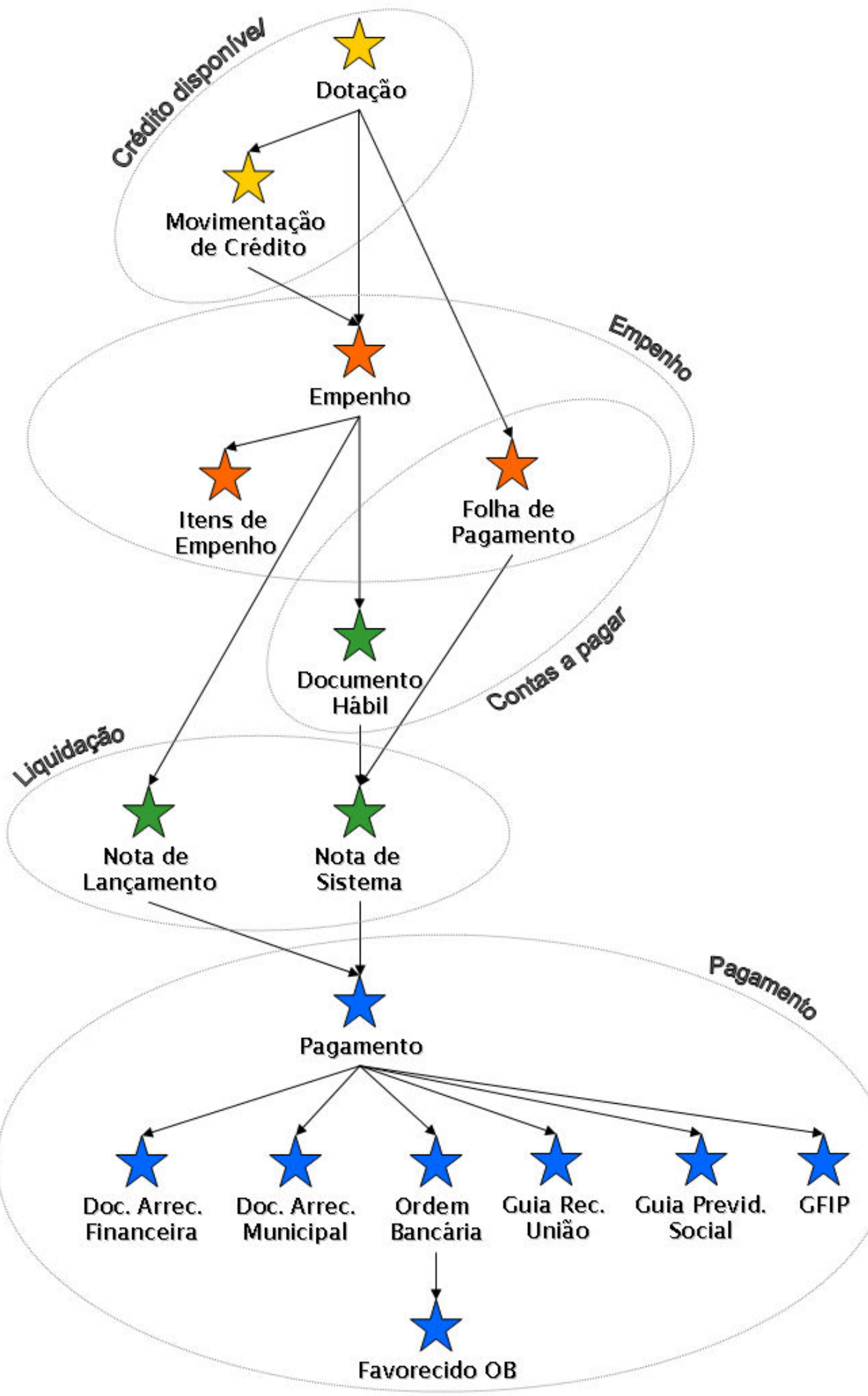

Figura 6 - Modelo em níveis 
O Documento Folha possui características próximas ao subsistema Contas a Pagar e a Receber (CPR) e pode ser considerado uma especialização do mesmo apenas para fins de folha de pagamento. Assim como no CPR, a transação da Folha também gera os compromissos a pagar e por isso é considerado como parte do tema contas a pagar.

A Folha de Pagamento, na transação ATUFOLHA, pode ser registrada pelos documentos - Apropriação Folha de Pessoal (FL), Folha de Pessoal - Pagamento por outro documento (FO), Reclassificação da despesa - Folha de Pessoal (FR) e Doc.de Estorno da Despesa Orçam. com Pessoal (FE).

A liquidação da despesa consiste na verificação do direito adquirido pelo credor, tendo por base os títulos e documentos comprobatórios do respectivo crédito. No SIAFI, antes da implantação do CPR, o registro da liquidação era feito pela Nota de Lançamento (NL). Com o CPR, a fase de liquidação passou a ser registrada de forma automática através de Notas de Sistema (NS). Nota de Lançamento e Nota de Sistema, portanto, registram a liquidação.

O pagamento refere-se à liberação de recursos para atendimento das despesas liquidadas. No SIAFI, o principal documento de pagamento é a Ordem Bancária, porém, outros documentos também registram saída de recursos: DAR, DARF, GPS, GRU e GFIP.

As Ordens Bancárias no SIAFI podem pagar mais de um credor, e neste caso são associadas a uma lista de credores. O contexto de análise Favorecido OB representa a lista de credores para as OBs que possuem mais de um credor.

O trabalho foi iniciado com a análise detalhada de cada documento, sua inclusão de dados e consulta, bem como a estrutura física das tabelas de dados. A partir disso, então, foram identificadas as informações constantes nos documentos, as informações em comum entre os documentos e as lacunas de informações existentes.

A seguir são detalhadas as principais peculiaridades encontradas na elaboração do modelo e as conseqüentes soluções adotadas para a ajustá-las às necessidades do escopo de informações gerenciais desejado ${ }^{1}$.

Algumas sugestões envolvem alterações no SIAFI, as quais estarão sublinhadas para melhor identificação.

\footnotetext{
${ }^{1}$ Acompanhamento da execução orçamentária e financeira baseado nos documentos do SIAFI.
} 


\subsection{Granularidade}

O modelo propõe uma base de dados será no nível de documentos. Mas alguns documentos registram mais de um evento ${ }^{2}$ e este, portanto será o menor detalhe de dados. Por exemplo, para um documento $\mathrm{DOC} 1$ qualquer (ND, $\mathrm{NC}, \mathrm{OB}$, etc) no valor de 150 que possua 2 eventos, tem-se o detalhe de cada linha do evento, conforme Quadro 1.

\begin{tabular}{cccccc}
\hline UG & Documento & Evento & Natureza de Despesa & Fonte de Recursos & Valor \\
\hline UGA & DOC1 & EVENTO1 & ND1 & FONTE1 & 100 \\
\hline UGA & DOC1 & EVENTO2 & ND2 & FONTE2 & 50 \\
\hline \multicolumn{5}{c}{ Quadro 1 - Granularidade é evento }
\end{tabular}

Os valores dos documentos, então, serão dados pela análise conjunta das linhas registradas para cada evento.

Embora o evento não seja uma informação necessária para o escopo definido ${ }^{3}$, optouse por inseri-lo no modelo apenas para facilitar a auditoria dos dados carregados.

\subsection{Os exercícios do SIAFI}

O SIAFI é estruturado por exercícios financeiros, sendo cada exercício armazenado em uma base de dados distinta. Isso significa que podem existir diferenças tanto de estrutura de tabelas, devido à criação ou à extinção de funcionalidades, quanto de significado dos dados, ou seja, um código significar "coisas" diferentes em exercícios diferentes. Assim, o primeiro desafio de um sistema de informações gerenciais que tenha o SIAFI como fonte de dados é a integração dos exercícios numa base única, homogênea e que garanta as informações da época da emissão dos documentos.

Observou-se que no SIAFI o significado dos dados mantém-se padrão e constante ao longo do tempo, por exemplo, um código de natureza de despesa ou de fonte de recursos não mudará de um exercício para o outro, a menos que haja uma reformulação completa nestas

\footnotetext{
${ }^{2}$ Código estruturado que identifica o fluxo contábil completo de atos ou fatos administrativos e que substitui, de forma automática, o tradicional procedimento de registro contábil mediante a indicação das contas devedoras e credoras que constituem um determinado lançamento.

${ }^{3}$ Acompanhamento da execução orçamentária e financeira baseado nos documentos do SIAFI
} 
tabelas. Mas vale ressaltar que o ideal seria que o SIAFI não permitisse o reaproveitamento de códigos entre os exercícios, de forma a manter sempre a integridade dos dados quando analisados entre diferentes exercícios.

Sendo assim, adotou-se uma solução de historiamento na qual os atributos possuam um código único independente do exercício, mesmo que um determinado código tenha existido para somente um determinado exercício. Isto porque as tabelas de dados são únicas para todos os exercícios e vão sendo atualizadas a medida que novos exercícios vão sendo incluídos na base de dados.A única desvantagem desta solução é que são mantidas apenas ou a última ou a primeira descrição associada ao código. Optou-se por manter a última descrição para todas as dimensões. Assim, como no exemplo ilustrado no Quadro 2, se uma UG A, cujo código é UGA, em 2008 tivesse a descrição UG A e em 2009 sua descrição fosse alterada para UNIDADE GESTORA A, os valores do atributo seriam atualizados, e a partir de 2009, nas consultas referentes a 2008 para a UGA será exibido UNIDADE GESTORA A.

\begin{tabular}{|c|c|c|c|}
\hline \multicolumn{2}{|c|}{ Tabela UG em 2008} & \multicolumn{2}{|c|}{ Tabela UG em 2009} \\
\hline Código & Descrição & Código & Descrição \\
\hline UGA & UG A & UGA & UNIDADE GESTORA A \\
\hline$\cdots$ & $\cdots$ & $\cdots$ & $\cdots$ \\
\hline
\end{tabular}

Mas há algumas exceções que devem ser tratadas. A primeira é em relação à estrutura dos órgãos públicos, conforme detalhado em 4.4 Estrutura administrativa. A segunda a ser tratada é em relação às alterações nos indicadores orçamentários, descrito em 4.5 PPI e PAC.

\subsection{Estrutura administrativa}

Com a criação, extinção e realocação, sobretudo de ministérios, é bastante comum que órgãos, e consequentemente suas Unidades Gestoras (UG) sofram alterações em sua estrutura hierárquica. Neste caso, a solução de historiamento não atenderia porque teríamos sempre a visão apenas da última estrutura hierárquica dos órgãos e isto inviabilizaria o histórico das informações. Optou-se, então, por manter UG e Órgão em dimensões distintas, perdendo-se com isso a hierarquia da dimensão. Mas, utilizando-se os atributos Órgão e UG juntamente 
com uma métrica é possível visualizar a hierarquia entre os mesmos, ou seja, de qualquer forma a hierarquia é mantida na tabela fato.

Mas os órgãos também possuem uma hierarquia própria composta de Órgão - Órgão Superior e Órgão Máximo. Este último ocorre, por exemplo, com a Presidência da República, Ministério da Defesa, Ministério das Comunicações, entre outros, onde estes podem assumir um papel de superioridade também em relação a outro Órgão Superior, conforme exemplo ilustrado na Figura 7.

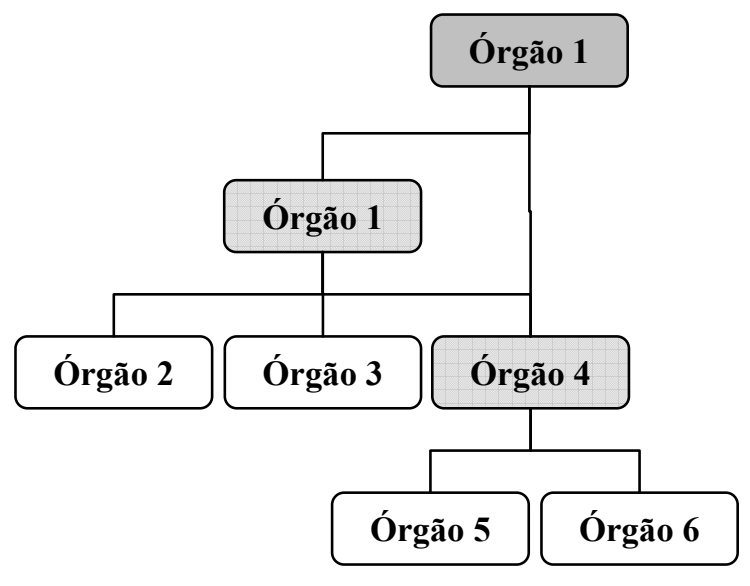

Figura 7 - Hierarquia entre órgãos

No Quadro 3 a seguir temos como ilustração a estrutura hierárquica da Presidência de República em maio de 2009.

\begin{tabular}{|c|c|c|c|}
\hline $\begin{array}{l}\text { Órgão } \\
\text { Máximo }\end{array}$ & $\begin{array}{l}\text { Órgão } \\
\text { Superior }\end{array}$ & Órgão & \\
\hline 20000 & 20000 & 20000 & PRESIDENCIA DA REPUBLICA \\
\hline PRESIDENCIA & PRESIDENCIA & 20101 & PRESIDENCIA DA REPUBLICA \\
\hline \multirow[t]{20}{*}{ DA REPUBLICA } & DA REPUBLICA & 20102 & GABINETE DA VICE-PRESIDENCIA DA REPUBLICA \\
\hline & & 20104 & SECRETARIA DE ASSUNTOS ESTRATEGICOS \\
\hline & & 20114 & ADVOCACIA-GERAL DA UNIAO \\
\hline & & 50000 & GAB.DO MINISTRO EXTRAORD.DE PROJ.ESPECIAIS \\
\hline & 20101 & 20115 & FUNDO NACIONAL PARA A CRIANCA E O ADOLESCENTE \\
\hline & PRESIDENCIA & 20116 & FUNDO DE IMPRENSA NACIONAL \\
\hline & DA REPUBLICA & 20117 & FUNDO NACIONAL ANTIDROGAS \\
\hline & & 20125 & CONTROLADORIA-GERAL DA UNIAO \\
\hline & & 20415 & EMPRESA BRASIL DE COMUNICACAO \\
\hline & & 20803 & SECRETARIA DE ADMINISTRACAO/CC/PR \\
\hline & & 24208 & INSTITUTO NAC.DE TECNOLOGIA DA INFORMACAO-ITI \\
\hline & & 25206 & INSTITUTO DE PESQUISA ECONOMICA APLICADA \\
\hline & & 30201 & RADIOBRAS - EMP.BRASILEIRA DE COMUNICACAO S/A \\
\hline & & 39811 & COMPANHIA DOCAS DO RIO DE JANEIRO \\
\hline & & 39812 & COMPANHIA DOCAS DO ESTADO DA BAHIA \\
\hline & & 39813 & COMPANHIA DOCAS DO CEARá \\
\hline & & 39814 & COMPANHIA DOCAS DO PARA - CDP \\
\hline & & 39815 & COMPANHIA DOCAS DO RIO GRANDE DO NORTE-CODERN \\
\hline & & 39816 & COMPANHIA DOCAS DO ESTADO DE SAO PAULO \\
\hline & & 39817 & COMPANHIA DOCAS DO ESPIRITO SANTO \\
\hline
\end{tabular}


Ocorre que a reestruturação de órgãos é bastante comum na administração pública brasileira, como por exemplo a alteração ilustrada na Figura 8, em que o Órgão 2 passou em 2009 a ser subordinado ao Órgão 4.

Estrutura administrativa em 2008

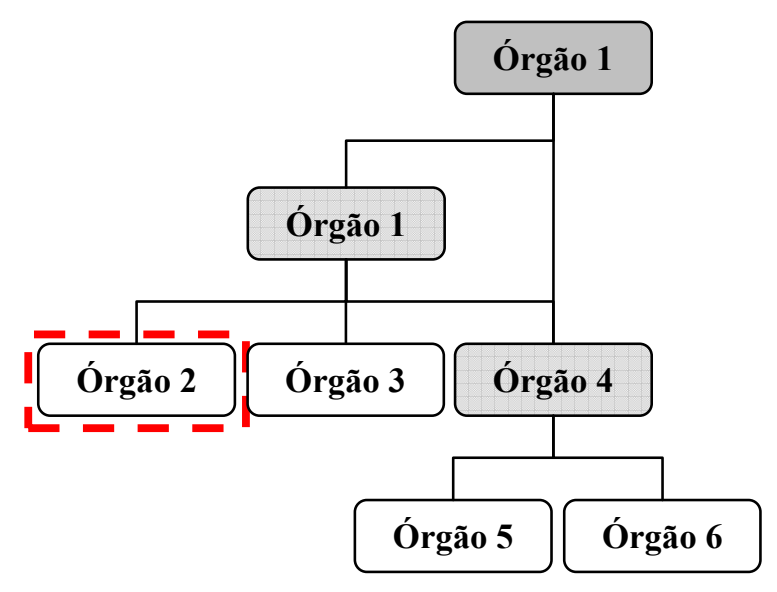

Estrutura administrativa em 2009

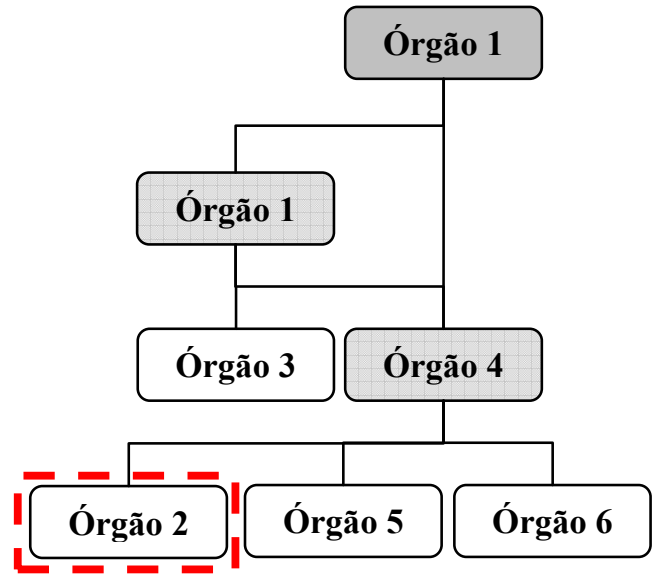

Figura 8 - Alteração na estrutura hierárquica

Nestes casos, para manter-se a hierarquia na dimensão, optou-se por fazer um historiamento diferenciado na dimensão Órgão, vinculando este a cada exercício.

Esta solução possui um arranjo que não é desejado em um modelo dimensional, mas que, após repetidos testes, mostrou-se satisfatória diante do problema a ser resolvido e do custo-benefício de sua aplicação. Para evitar que o usuário do data warehouse visualizasse os órgãos na forma Órgão 1 de 2008, Órgão 1 de 2009, ou seja, uma registro de órgão para cada exercício, situação que não seria confortável, mantive-se uma tabela de órgão única e uma tabela de relacionamento entre os órgãos e os exercícios. Cabe salientar que esta é uma solução muito mais física do que conceitual, e pode até não ser representada no modelo dimensional, mas o levantamento deste requisito ocorre na fase de modelagem e precisa ser documentado de forma a garantir o sucesso da implementação da solução.

Representamos uma linha tracejada entre Órgão e Exercício de forma a evidenciar esta ligação física a ser feita (Figura 9). Salientamos ainda que esta notação foi criada a partir desta necessidade e não representa uma notação conhecida. 


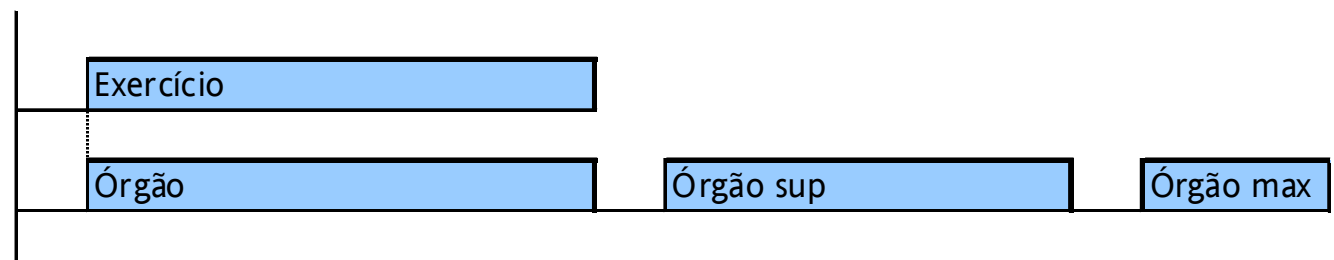

Figura 9 - Relacionamento órgão x exercício

Fisicamente, o relacionamento entre as tabelas seria como descrito no Quadro 4.

Tabela órgão

\begin{tabular}{cccc}
\hline Exercício & Órgão & Órgão Sup & Órgão Max \\
\hline 2008 & ORG1 & ORG1 & ORG1 \\
\hline 2008 & ORG2 & ORG1 & ORG1 \\
\hline 2008 & ORG3 & ORG1 & ORG1 \\
\hline 2008 & ORG4 & ORG1 & ORG1 \\
\hline 2008 & ORG5 & ORG4 & ORG1 \\
\hline 2008 & ORG6 & ORG4 & ORG1 \\
\hline 2009 & ORG1 & ORG1 & ORG1 \\
\hline 2009 & ORG2 & ORG4 & ORG1 \\
\hline 2009 & ORG3 & ORG1 & ORG1 \\
\hline 2009 & ORG4 & ORG1 & ORG1 \\
\hline 2009 & ORG5 & ORG4 & ORG1 \\
\hline 2009 & ORG6 & ORG4 & ORG1 \\
\hline$\ldots$ & $\ldots$ & $\ldots$ & $\ldots$ \\
\hline & Quadro 4 - Tabela órgão & \\
\hline & & & \\
\hline
\end{tabular}

\section{5. $\mathrm{PPI}^{4}$ e PAC $^{5}$}

\footnotetext{
${ }^{4}$ O Programa de Aceleração do Crescimento (PAC) é um programa do governo federal brasileiro que engloba um conjunto de políticas econômicas, planejadas para os quatro anos seguintes, e que tem como objetivo acelerar o crescimento econômico do Brasil, sendo uma de suas prioridades o investimento em infra-estrutura, em áreas como saneamento, habitação, transporte, energia e recursos hídricos, entre outros. Fonte: http://pt.wikipedia.org/wiki/Programa_de_Aceleração_do_Crescimento em 30/05/2009.

${ }^{5}$ O Projeto Piloto de Investimentos (PPI) foi lançado em 2005, com objetivo principal de melhorar a qualidade e eficiência do gasto público, através do rigoroso processo seletivo dos projetos, planejamento detalhado das ações, garantia do fluxo de recursos necessários ao seu andamento e monitoramento da execução física e financeira. Os gastos referentes ao PPI podem ser abatidos da meta de Resultado Primário do Governo Federal, prerrogativa legal que está associada ao elevado retorno fiscal esperado com a efetiva implementação destes projetos.
} 
Nos últimos exercícios, a classificação os indicadores têm sofrido alterações devido ao PAC e ao PPI. Muitos projetos de infra-estrutura já em andamento foram, e podem continuar sendo, incluídos nas carteiras do PAC e do PPI. Os projetos do PPI são identificados pelo "Indicador de Resultado Primário igual a 3 - PRIMÁRIO SEM IMPACTO FISCAL". Já os projetos do PAC têm o "Indicador de Programação Selecionada igual a 1 ou 2."

No modelo dimensional ora proposto, se apenas os indicadores orçamentários originais fossem mantidos não seria possível obter informações atuais destes projetos; se fossem mantidas apenas as últimas classificações o seu histórico seria perdido. Assim, para recuperar corretamente as informações de PPI e PAC, a opção foi incluir os valores atuais dos indicadores Resultado Primário e Programação Selecionada (Figura 10).

\begin{tabular}{|c|c|}
\hline Lei Calmon & \\
\hline Exceção decreto & \\
\hline Obras irregulares & \\
\hline E rradicação analfabetis mo & \\
\hline Resultado lei & \\
\hline RP es tratégico & \\
\hline RP resultado lei & \\
\hline Permite empenho & \\
\hline Precatório & \\
\hline Crédito & \\
\hline RP Resultado E OF & \\
\hline Resultado E OF & \\
\hline Ação es sencial & \\
\hline Progr. selecionadas & \\
\hline Progr.selecionadas atual & \\
\hline R esultado primário a tual & \\
\hline
\end{tabular}

Figura 10 - Indicadores orçamentários

Assim, por exemplo, se uma determinada obra cujo empenho foi emitido em março de 2008 passar a ser obra do PAC em jan/2009, seu indicador Programações selecionadas atual deve refletir esta alteração. Todas as outras informações permanecem inalteradas conforme mostra o Quadro 5. Desta forma mantém-se no indicador Programações selecionadas a informação original do empenho e no indicador Programações selecionadas atual a situação atual. 
Em mar/2008

\begin{tabular}{cccccc}
\hline Exercício & UG & $\begin{array}{c}\text { Num } \\
\text { NE }\end{array}$ & Programações selecionadas & Programações selecionadas atual & Valor \\
\hline \multirow{2}{*}{2008} & UGA & NE01 & $\begin{array}{c}\text { 3 - Outras Programações Sem } \\
\text { Impacto Primário }\end{array}$ & 3- Outras Programações Sem \\
& & & & & 1.000 \\
\hline$\ldots$ & & & & \\
\hline
\end{tabular}

Em mar/2009

\begin{tabular}{cccccc}
\hline Exercício & UG & $\begin{array}{c}\text { Num } \\
\text { NE }\end{array}$ & Programações selecionadas & Programações selecionadas atual & Valor \\
\hline \multirow{2}{*}{2008} & UGA & NE01 & $\begin{array}{c}\text { 3- Outras Programações Sem } \\
\text { Impacto Primário }\end{array}$ & 1- Programações Selecionadas Com & 1.000 \\
\hline$\ldots$ & & & & & \\
\hline
\end{tabular}

Quadro 5 - Programações selecionadas

No SIAFI e no SIAFI Gerencial mantém-se apenas a classificação atual, perdendo-se o histórico.

\subsection{Os diferentes papéis}

Uma grande preocupação de uma modelagem dimensional é identificar de forma unívoca as diferentes representações de dados que apontem para tabelas físicas únicas. Chamamos isso de "identificar os papéis". O conceito de UG no SIAFI é um exemplo de como uma tabela única pode assumir diferentes papéis informacionais: temos a UG Executora, a UG Emitente do Documento, a UG Responsável, etc. Na Figura 11 temos o exemplo de UG e Data.

Os diferentes papéis estão representados no modelo como atributos diferentes, cada um nomeado de forma a identificar a qual informação se refere. Fisicamente estes dados poderão apontar para uma tabela única. 

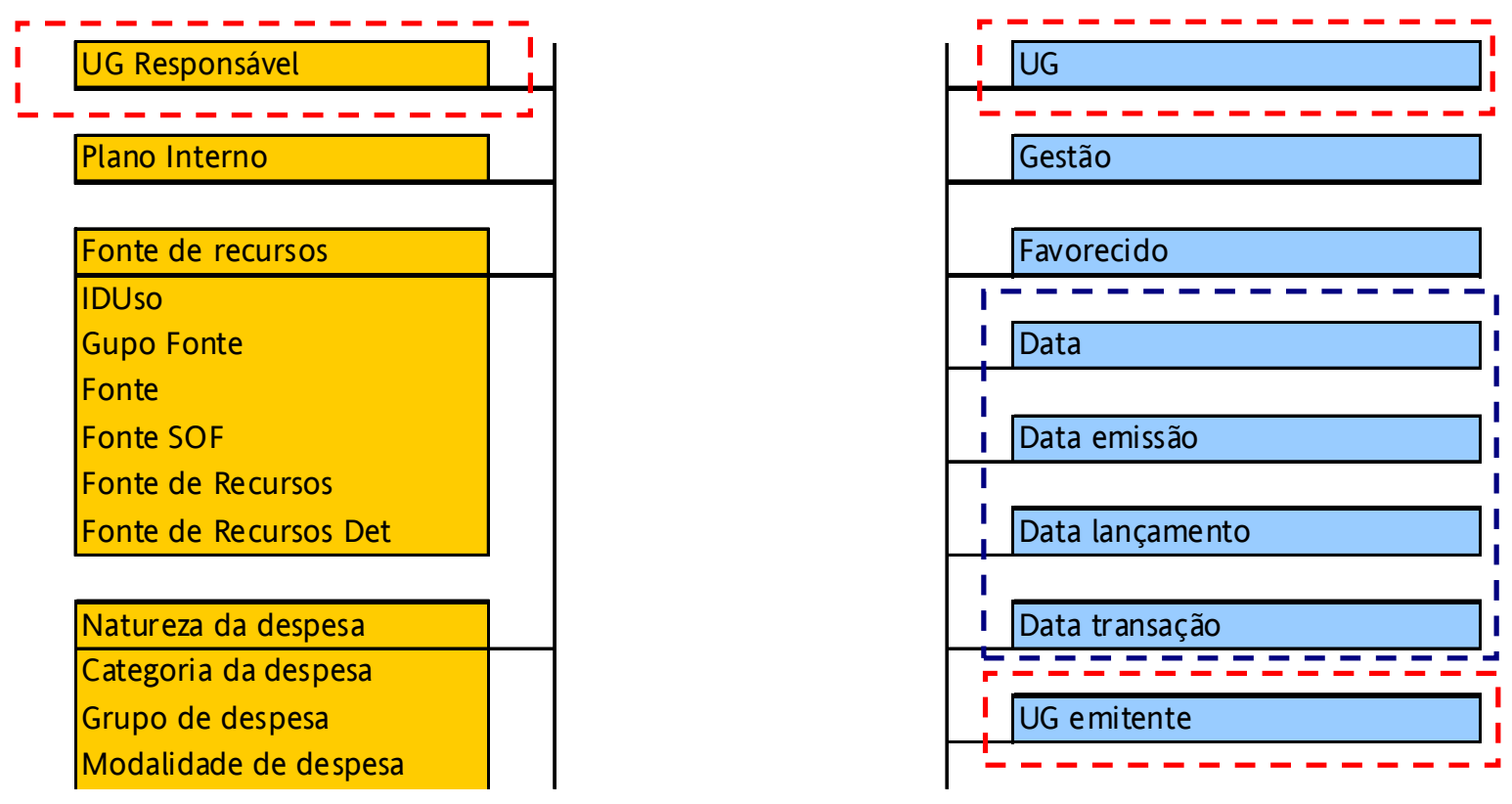

Figura 11 - Os diferentes papéis de UG e data

\subsection{Datas}

Para facilitar a execução de consultas, optou-se por disponibilizar uma hierarquia completa de datas, possibilitando ao usuário uma maior agilidade nas consultas.

Assim, para cada data, temos Dia-Decêndio-Mês-Bimestre-Trimestre-QuadrimestreSemestre-Ano.

Por questões de apresentação do modelo, optou-se por sublinhar os atributos data, indicando que se trata de uma dimensão composta por vários outros atributos. A Figura 12 exibe os atributos que compõem cada dimensão. 


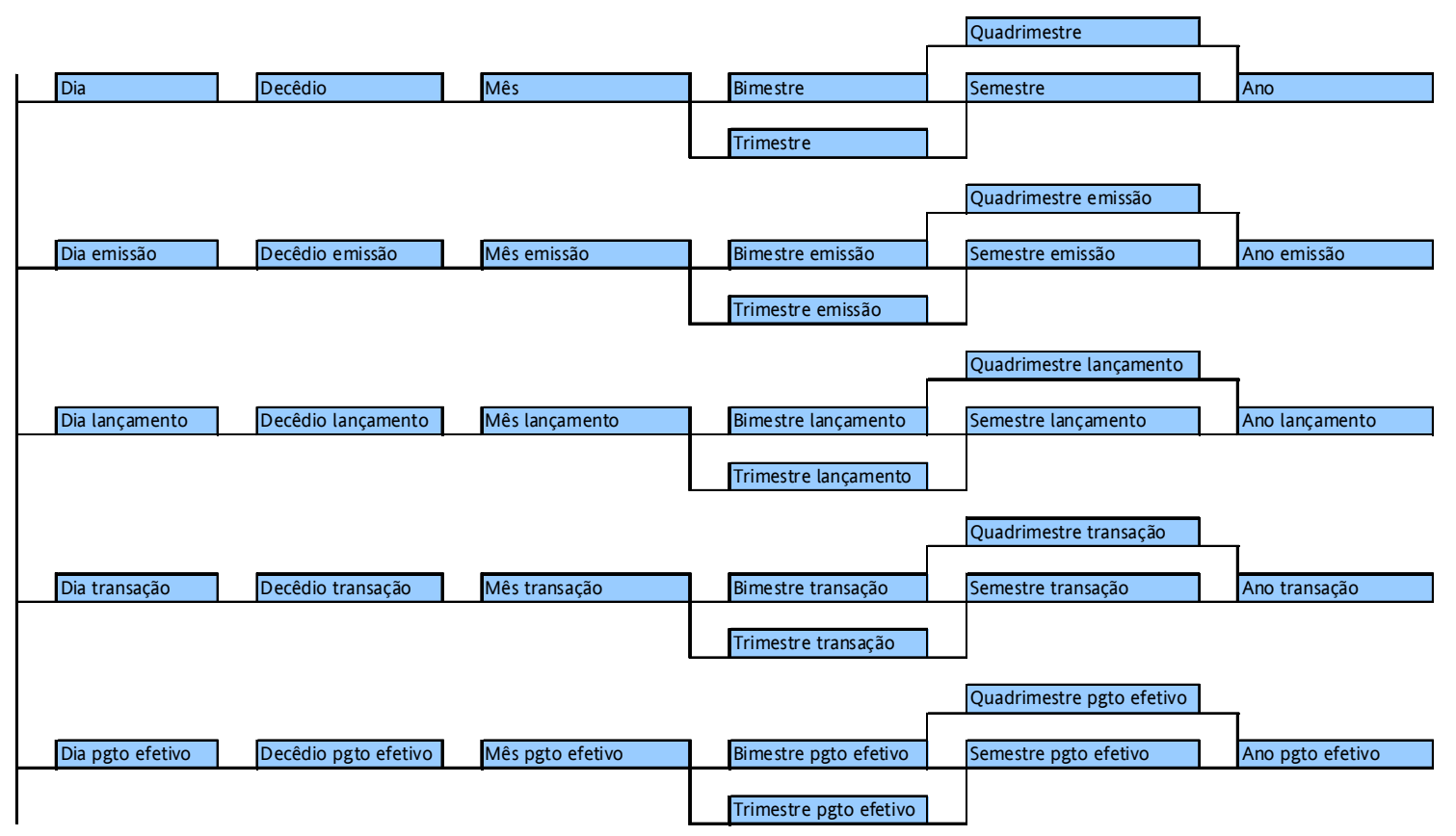

Figura 12 - Hierarquia de data

\subsection{Datas de emissão, lançamento e transação}

Os documentos do SIAFI possuem três diferentes datas associadas, sendo a principal delas a que chamamos de "Data de Lançamento", a data da efetiva contabilização do mesmo.

Quando um documento é cadastrado no SIAFI, o sistema registra automaticamente a data, a qual chamamos de "Data da Transação". Já a "Data de Emissão" é informada pelo usuário. Uma vez que no SIAFI é permitida a inclusão retroativa de documentos, é bastante comum, principalmente quando dois meses ficam abertos para atualização, que a data de emissão seja diferente da data de transação.

A data de emissão, portanto, é a base para o lançamento e coincide com a data de lançamento.

Mas, em algumas situações específicas e incomuns, o sistema permite que se emita um documento com uma data de emissão de um mês já fechado. Mas, como este mês não permitirá mais lançamentos, o sistema automaticamente contabiliza o documento no primeiro dia útil do mês aberto. Nesta situação, então, teremos uma data de lançamento diferente da data de emissão e da data de transação. 


\subsection{Barramentos}

Entre os diferentes contextos de análise em estudo temos algumas informações que são comuns aos diferentes temas. Chamamos estas informações de barramentos, pois tornarão possível o cruzamento dos dados.

Observa-se que Exercício, Órgão e os atributos da célula orçamentária são barramentos entre os diversos contextos. Assim, será possível recuperar informações, por exemplo, do que foi dotado, empenhado, liquidado e pago por determinados órgão para um dado programa entre os diferentes exercícios.

Um dos barramentos mais importantes é a Data, porém, conforme observamos no tópico 4.8 Datas de emissão, lançamento e transação, cada documento possui estas três datas. E ainda, para os documentos de pagamentos temos a Data de Pagamento Efetivo (conforme item 4.26 Pagamento Efetivo x Data Saque).

Devido à importância da Data de Pagamento Efetivo para o controle do fluxo financeiro, optou-se por carregar o barramento Data no contexto de análise de Pagamentos com a Data de Pagamento Efetivo, e em todos os demais contextos de análise com a Data de Lançamento do respectivo documento.

É importante observar que o usuário deve ter o entendimento correto sobre esta dimensão Data para que não sejam feitas interpretações equivocadas sobre o resultado das consultas realizadas, pois o regime será de caixa para os pagamentos e de competência para os demais documentos.

Assim como a data, a UG também possui diferentes papéis. Temos a UG Emitente, a UG Favorecida, a UG Responsável, etc. E conforme veremos em 4.12. Movimentação de Créditos, nem sempre a UG Emitente do documento deverá ser a UG do contexto. No caso específico da Movimentação de Crédito, a UG será carregada a partir de uma transformação realizada nos dados, em todos os demais contextos será a mesma UG Emitente do respectivo documento. 


\subsection{Câmbio}

Uma Unidade Gestora que se localiza no exterior executa seu orçamento na moeda do país em que se encontra. Assim, por exemplo, os empenhos emitidos por uma UG que se encontra em Washington terão serão valores registrados em dólar.

Os valores em outras moedas, portanto, devem ser convertidos para Real para evitar distorções nas consultas consolidadas por órgão. A conversão deve ser realizada de acordo com a taxa de câmbio do dia, registrada automaticamente pelo SPB na transação CONCAMBIO.

Mas, para manter compatíveis os saldos de contas com registro no país e contrapartida no exterior, o SIAFI possui uma UG específica, chamada UG de Diferença Cambial $^{6}$ na qual são registrados de forma automática os lançamentos da variação cambial através de documentos NSs do tipo SV. Os lançamentos feitos nesta UG são independentes, e não afetam os lançamentos originais.

Por se tratar de procedimento específico, estes documentos NSs devem ser considerados juntamente com os documentos originais correspondentes. O evento registrado na NS do tipo SV determinará a qual contexto de análise se refere (dotação, empenho ou liquidação) ${ }^{7}$ e conseqüentemente em qual tabela fato deve ser carregada. Assim, uma NSs que esteja realizando ajustes referentes ao valor empenhado, por exemplo, deve ser carregada na tabela fato empenho. Observa-se apenas que neste caso, as informações específicas do empenho devem ficar nulas.

\subsection{Dotação}

As informações sobre as dotações orçamentárias no modelo proposto serão extraídas dos documentos Nota de Dotação (ND) e as respectivas classificações dos créditos em Inicial, Suplementar, Especial, Extraordinário, Cancelado, Especial reaberto, Extraordinário reaberto,

\footnotetext{
${ }^{6}$ Todo Órgão que tenha UG em moeda estrangeira devera possuir uma, e apenas uma, UG de Diferença Cambial. Ainda que o Órgão possua mais de uma UG em moeda estrangeira, ou que essas UG sejam em mais de uma moeda estrangeira os ajustes deverão ser feitos em uma única UG de Diferença Cambial. Fonte: Manual SIAFI.

${ }^{7}$ Não há pagamentos registrados em outras moedas.
} 
Bloqueio e Contingenciamento são oriundas dos eventos registrados nas NDs, os quais serão classificados num atributo chamado Espécie ND.

A Dotação Inicial, por exemplo, é a soma dos valores de NDs cuja espécie seja igual a "Inicial”. Da mesma forma, os Créditos Contingenciados serão a soma dos valores de NDs com espécie "Contingenciamento". Todas as outras informações seguirão a mesma lógica.

É importante salientar que a transformação dos eventos em "Espécie ND" é transparente ao usuário final, que não precisa conhecê-los para realizar consultas no sistema. Esta vantagem ao usuário traz um esforço adicional da equipe de manutenção do sistema, que necessita de uma gestão de requisitos atenta a possíveis alterações nos eventos.

Esta facilidade e esta preocupação serão repetidas para a extração de todos os documentos, pois o modelo está embasado fortemente no conceito de "Espécie" do documento. Optou-se por esta solução, pois as alterações em eventos deste tipo são raras e o benefício trazido ao usuário é muito superior ao custo de manutenção desta solução.

O valor total dotado, que chamamos de "Lei + Créditos" é Dotação Inicial + Créditos Suplementares + Créditos Especiais + Créditos Extraordinários - Créditos Cancelados + Créditos Especiais Reabertos + Créditos Extra Reabertos, ou seja, uma composição de métricas.

Temos ainda Crédito bloqueado e o Contingenciamento, ambos recuperados também da espécie da NC.

\subsection{Movimentação de Créditos}

A movimentação de créditos ocorre a partir das descentralizações dos recursos, operação esta que se utiliza de um único documento e envolve duas UGs distintas: uma repassando e outra recebendo. Assim, para cada documento de Movimentação de Crédito temos uma UG Emitente e uma UG Favorecida, sendo que a primeira tem uma diminuição no valor de sua dotação, e a segunda um aumento. Como é necessário que o valor descentralizado seja diminuído da UG Emitente e seja somado à Favorecida, teremos que realizar uma transformação nos dados originais de forma que as consultas retornem os valores corretos para ambas as UGs. Como citado anteriormente em 4.9 Barramentos, no caso específico das NCs, a dimensão UG será carregada ora é com a UG emitente, ora com a UG favorecida. 
Cada documento NC emitido será duplicado, sendo que para a UG Emitente temos que a espécie da NC é "Descentralização Concedida" Já para a UG Favorecida temos o mesmo documento mas com espécie "Descentralização Recebida".

Assim, supondo uma NC01 emitida pela UGA e tendo a UGB como favorecida, teríamos a seguinte transformação exibido Quadro 6.

\begin{tabular}{cccccc}
\hline UG & UG Executora & Num NC & UG Favorecida & Espécie NC & Valor \\
\hline UGA & UGA & NC1 & UGB & Desc. Concedida & 100 \\
\hline UGB & UGA & NC1 & UGB & Desc. Recebida & 100 \\
\hline
\end{tabular}

\section{Quadro 6 - UGs Executora e Favorecida da NC}

A Dotação disponível para uma UG será a sua dotação autorizada na lei mais os créditos adicionais, métrica que chamamos de "Lei + Créditos" somada às suas descentralizações recebidas e diminuídas das suas descentralizações concedidas.

Assim, supondo-se ainda que a UGA tenha uma "Lei + Créditos" de 1.000 e a UGB de 200, temos que a Dotação disponível das UGs A e B serão as exibidos no Quadro 7.

\begin{tabular}{lcccc}
\hline UG & "Lei + créditos" & Desc. Recebidas & Desc. Concedidas & DOTAÇÃO DISPONÍVEL \\
\hline UGA & 1000 & 0 & 100 & 900 \\
\hline UGB & 200 & 100 & 0 & 300 \\
\hline
\end{tabular}

Quadro 7 - Dotação disponível

Em complemento à informação de descentralização concedida ou recebida, e a partir do evento utilizado no documento, a descentralização será classificada ainda em interna ou externa. A espécie da NC, também com base no evento do documento, classificará ainda a movimentação do crédito em anulação ou devolução.

As métricas, recuperadas a partir da espécie da NC, serão Desc. interna receb., Desc. interna conc., Desc. externa receb. e Desc. externa conc.

Por fim, a Dotação disponível será igual a Lei + Créditos - Contingenciamento Crédito Bloqueado + Desc.Interna Recebida - Desc.Interna Concedida + Desc. Externa Recebida - Desc. Externa Concedida.

Para facilitar a implementação de métricas compostas, como a Dotação Disponível, em vez de criá-las como o somatório de outras, uma boa opção é criar um indicador de 
espécie que seja 1 ou -1, e utilizar como fórmula da métrica a Soma (valor_doc*ind_especie). Desta forma, conceitualmente e métrica continua como a composição de outras, mas fisicamente a consulta será otimizada, pois será necessária apenas uma única consulta ao banco de dados. Esta mesma solução pode ser adotada para as várias métricas compostas que citaremos a seguir.

\subsection{Empenho}

Um empenho emitido pode ser reforçado, anulado ou cancelado por outro empenho.

Chamaremos o empenho originalmente emitido de Empenho Original ou simplesmente Empenho. A todo empenho emitido, seja ele original, de reforço, de anulação ou de cancelamento chamaremos de Empenho Referência. Assim, é possível criar um relacionamento entre os empenhos de forma a identificar quais estão reforçando, anulando ou cancelando um empenho original, bem como identificar o seu valor empenhado atual.

A classificação em original, de reforço, de anulação ou de cancelamento é dada pela Espécie NE, que é um atributo apenas do Empenho Referência. O Empenho será sempre o original.

Supondo que temos uma UGA que emitiu um empenho NE1 no valor de 1000. Posteriormente este empenho foi reforçado pelo empenho NE2 no valor de 200 e em seguida em mais 300 pelo empenho NE3. Esta mesma UG também emitiu o NE4 no valor de 2000, mas depois resolveu anulá-lo em 800 através do NE5. Trazendo estes empenhos para a nossa base de dados, teríamos os dados exibidos no Quadro 8.

\begin{tabular}{lcccc}
\hline UG & NE original & NE referência & Espécie NE & Valor \\
\hline UGA & NE1 & NE1 & Original & 1000 \\
\hline UGA & NE1 & NE2 & Reforço & 200 \\
\hline UGA & NE1 & NE3 & Reforço & 300 \\
\hline UGA & NE4 & NE4 & Original & 2000 \\
\hline UGA & NE4 & NE5 & Anulação & 800 \\
\hline \multicolumn{5}{c}{ Quadro 8 - Empenho original e referência }
\end{tabular}


Temos que o valor empenhado será igual ao valor original + reforço - anulação cancelamento, então, o Valor empenhado atual do NE1 é igual a $1500(1000+200+300)$ e do NE4 é 1200 (2000 - 800).

Conceitualmente, então, existe uma hierarquia entre Empenho e Empenho Referência, conforme Figura 13. Na implementação desta solução, porém, pode ser considerada a possibilidade de manter as duas informações ligadas diretamente à tabela fato, de forma a facilitar a carga e a agilizar as consultas. Esta mesma sugestão se aplica para todos os documentos que possuem um documento referência correspondente.

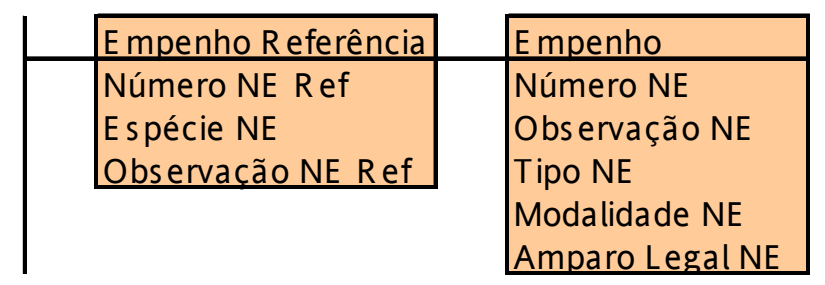

Figura 13 - Hierarquia empenho original e referência

\subsection{Restos a pagar ${ }^{8}$}

Os restos a pagar (RP) são empenhos que não foram pagos e que passam de um exercício para o outro. Como a base de dados do modelo proposto possui vários exercícios integrados e como no SIAFI todo o controle de RP é feito pelas contas contábeis e contas correntes, é necessária uma transformação nos dados de origem para tornar a informação consistente com o sistema fonte.

A solução mais adequada encontrada foi no final do exercício ler das contas contábeis de inscrição de restos a pagar os documentos empenhos registrados em seus conta correntes e então carregá-los para o data warehouse considerando uma nova data de lançamento em 01 de janeiro do exercício seguinte à sua inscrição.

Assim, por exemplo, um Empenho NE01 da UGA emitido em 2008 no valor de 1000, que tenha sido inscrito em RP com um valor de 500, é carregado no exercício de 2009 com data de lançamento de 01/jan/2009 e marcado como RP através do Indicador RP, conforme

\footnotetext{
${ }^{8}$ Representam as despesas empenhadas e não pagas até 31 de dezembro, distinguindo-se as despesas processadas das não processadas. Entende-se por processadas e não processadas, respectivamente, as despesas liquidadas e as não liquidadas. (art. 67, Decreto n 93.872, de 23 de dezembro de 1986). Fonte: Manual SIAFI.
} 
mostra a Figura 14. Para simplificação, utilizaremos apenas a data de lançamento, considerando-se que a data de emissão será na mesma data.

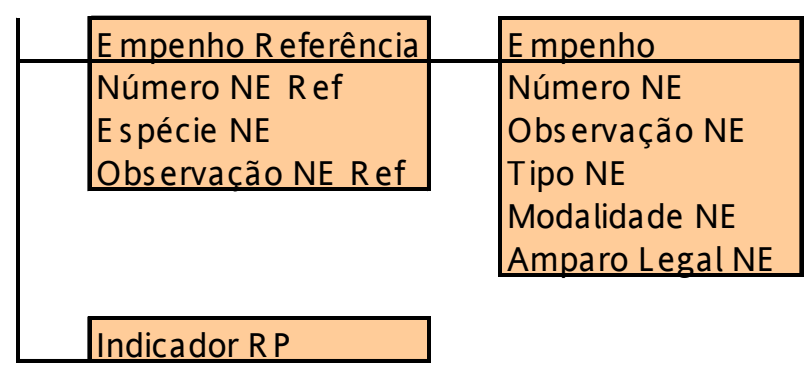

\begin{tabular}{clcccccc}
\hline Exercício & UG & Empenho & Empenho Referência & Data NE Ref & Espécie NE & Indicador RP & Valor \\
\hline 2008 & UGA & NE01 & NE01 & $01 /$ jul/08 & Original & - & 1.000 \\
\hline 2009 & UGA & NE01 & NE01 & $01 /$ jan/09 & Original & RPP & 500 \\
\hline
\end{tabular}

Figura 14 - Restos a pagar

As métricas de restos a pagar são construídas a partir do indicador de RP, que os classifica como Processado ou Não-Processado, de acordo com a conta contábil lida. O exemplo acima trata, portanto, de um resto a pagar processado.

Para que o valor inscrito não seja contabilizado como empenhado no exercício seguinte, a métrica de Valor Empenhado deve considerar apenas os registros cujo indicador de RP seja nulo.

O controle dos RPs pagos também será feito pelo indicador de RP, conforme métrica Valor RP pago descrita no Apêndice B.

Caso o RP seja anulado ou cancelado, mantém-se a mesma lógica de carga Empenho versus Empenho Referência. Assim, se em 01 de fevereiro o empenho NE01, do exemplo acima, fosse anulado em 200 através do NE02, teríamos a carga exibida no Quadro 9.

\begin{tabular}{cccccccc}
\hline Exercício & UG & Empenho & Empenho Referência & Data NE Ref & Espécie NE & Ind RP & Valor \\
\hline 2008 & UGA & NE01 & NE01 & $01 /$ jul/08 & Original & - & 1.000 \\
\hline 2009 & UGA & NE01 & NE01 & $01 /$ jan/09 & Original & RPP & 500 \\
\hline 2009 & UGA & NE01 & NE02 & $01 /$ fev/09 & Anulação & ARP & 200 \\
\hline
\end{tabular}

Quadro 9 - Anulação de restos a pagar

Para possibilitar uma melhor análise dos dados, separando-se o que é inscrição e o que anulação ou cancelamento dos restos a pagar, o indicador de RP nestes últimos casos seria 
“Atualização de RP (ARP)". A classificação de anulação ou cancelamento é dada pela Espécie NE.

É importante salientar que como neste processo específico o data warehouse utiliza-se das contas contábeis, alterações nestas contas no SIAFI devem ser refletidas nos processos de carga do DW.

\subsection{Documento hábil}

O CPR é o subsistema do SIAFI que otimiza o processo de programação financeira das unidades gestoras. Recibos, notas fiscais ou outros documentos em papel são cadastrados no sistema e dão origem aos Documentos Hábeis. A partir da situação destes documentos hábeis são gerados as NSs de liquidação e os documentos de pagamento. Na grande maioria das operações do CPR a Nota de Empenho é o documento de referência que serve de base para a geração do documento hábil.

O CPR é, portanto o ponto de contato entre o empenho, a liquidação e o pagamento. A transação CONMOVDOC ${ }^{9}$ é a base para a carga de dados do modelo proposto uma vez que dela serão extraídos os relacionamentos entre os empenhos, os documentos hábeis, as notas de sistema que realizam a liquidação da despesa e os respectivos pagamentos. A composição completa da CONMOVDOC está na tabela fato pagamento.

No escopo deste modelo de dados optou-se por trazer apenas o número, o tipo e a situação do documento hábil ${ }^{10}$, mas o CPR é uma fonte de dados muito rica que pode ser depois incorporada a este modelo através de uma tabela fato própria.

O tipo do documento hábil já traz em si uma rica fonte de informações gerenciais uma vez que a partir dele é possível realizar consultas, por exemplo, das despesas com autorização de viagens, notas fiscais, suprimentos de fundos, sentenças judiciais e precatórios, etc.

\footnotetext{
${ }^{9}$ CONMOVDOC é a transação no SIAFI que permite a consulta da movimentação dos documentos do CPR, dando a possibilidade de recuperar: a) a partir de um documento hábil, as informações sobre a quais documentos ele se refere, por quais documentos ele é referenciado e por quais documentos ele foi recebido/pago; e b) a partir de um documento SIAFI, as informações sobre que documento ele recebeu/pagou.

${ }^{10} \mathrm{O}$ Documento hábil e Folha de pagamento foram mostrados como contextos de análise diferentes no modelo em níveis apenas para fins didáticos dos temas apresentados.
} 


\subsection{Folha de pagamento versus documento hábil}

Como os pagamentos registram como Documento Origem tanto Documentos Hábeis do CPR quanto Documentos Folha, a solução no modelo dimensional foi considerar que o Documento Folha é um tipo de documento hábil que possui atributos específicos como o a Situação da folha e a Dedução da folha.

Dessa forma é possível interligar Documento hábil e Folha de pagamento à tabela fato pagamento através do barramento Documento hábil.

\begin{tabular}{|c|c|}
\hline Folha de pagamento & Documento hábil \\
\hline Número folha pgto & Número doc hábil \\
\hline Observação folha pgto & Tipo doc hábil \\
\hline Situação da folha & Situação doc hábil \\
\hline Dedução da folha & \\
\hline
\end{tabular}

\subsection{Folha de pagamento - FL versus FP}

Em 2008 foi implantado no SIAFI no novo Documento Folha, em que todos os registros ficam contabilizados e vinculados a apenas um documento, diferente da sistemática anterior, em que para a execução da folha de pagamento havia a necessidade de geração de diversos documentos. (MANUAL SIAFI, 2009).

Antes da implantação do subsistema Folha, utilizava-se o documento FP - Folha de Pagamento do CPR. Porém, muitos órgãos ainda continuam utilizando este documento, além do Documento Folha, para registro de pagamento de pessoal. Foi observada a sua utilização para pagamento de horas extras, adicional noturno, folha suplementar, entre outros.

$\underline{\mathrm{O} \text { ideal seria que toda a despesa referente a pagamento de pessoal fosse realizada no }}$ $\underline{\text { SIAFI através do documento folha para que a informação não ficasse fragmentada entre }}$ documentos diferentes. 


\subsection{Folha de pagamento - estorno e reclassificação}

O documento folha do tipo Apropriação Folha de Pessoal - Atufolha (FL) é o principal documento utilizado pelo subsistema folha de pagamento do SIAFI e guarda os valores apropriados em nível de célula orçamentária.

O documento folha do tipo Doc. de Estorno da Despesa Orcam. com Pessoal (FE) é utilizado para realizar estornos de apropriações de despesas realizadas através dos documentos FL. No entanto o SIAFI não vincula a informação do documento de estorno (FE) com o seu respectivo original (FL). Desta forma a única ligação entre a apropriação original da despesa e o estorno é a célula orçamentária.

O documento folha do tipo Reclassifição da Despesa - Folha de Pessoal (FR) é utilizado quando é necessário reclassificar as apropriações já realizadas (por documentos FL) em outras células. Da mesma forma que o FE, não existe ligação entre o FR e o FL no SIAFI.

$\underline{O}$ ideal seria que o SIAFI mantivesse o relacionamento entre os documentos FR e FE gerados e os respectivos FLs originais, tal como mostrado na Figura 15.

\begin{tabular}{|l|l|}
\hline $\begin{array}{l}\text { Folha de pagamento referência } \\
\text { Número folha pgto ref }\end{array}$ & Folha de pagamento \\
Espécie folha & $\begin{array}{l}\text { Número folha pgto } \\
\text { Observação folha pgto }\end{array}$ \\
\hline
\end{tabular}

Figura 15 - Folha original e referência

\subsection{Folha de pagamento - pagamento por FO}

Alguns valores de folha de pessoal podem ser registrados na transação ATUFOLHA em documentos do tipo Folha de Pessoal - Pagamento por Outro Documento. (FO) para serem pagos posteriormente através do CPR.

Como o CPR não possui tratamento para a célula da despesa como a Folha, contabilmente a folha é considerada como paga no momento do registro do documento FO e não no pagamento de fato.

Neste caso, então, é perdida a ligação entre o documento de pagamento e o documento folha (já que o pagamento é gerado no CPR através do documento do tipo DT). 
O ideal seria que o CPR solicitasse ao usuário que informasse qual o documento FO está sendo pago. Desta forma a rastreabilidade entre a folha e o documento de pagamento estaria garantida.

\subsection{Folha de pagamento - documento de pagamento}

A utilização do Documento Folha dispensa o uso das transações NE ${ }^{11}$ e ATULI ${ }^{12}$, o que não quer dizer que não haja o empenho. O que ocorre é que o usuário, no momento que estiver apropriando a despesa com pessoal, dentro do documento folha, estará executando registros, de forma automática e concomitante, por meio de NS, relativos aos estágios de empenho e liquidação (MANUAL SIAFI, 2009).

Como não há o documento nota de empenho, os documentos de pagamento registram apenas as informações financeiras (fonte de recursos, vinculação de pagamento e categoria de gastos) e são, portanto, uma exceção em relação aos demais pagamentos de despesas. Para se obter a célula orçamentária correspondente ao pagamento é necessário verificar os lançamentos contábeis.

Assim, para o caso específico da folha de pagamento gerada pelo documento FL a solução é obter as informações orçamentárias lendo-se os lançamentos realizados pelo evento 581400 na conta contábil 29213.03.01 - CREDITO PAGO.

$\underline{\mathrm{O} \text { ideal seria que as informações orçamentárias e financeiras fossem registradas numa }}$ conta contábil de controle, como descrito em 4.34 Informação orçamentária x financeira.

\subsection{Folha de pagamento - créditos orçamentários}

O Documento Folha possui uma tela específica de Créditos para o registro de valores a pagar aos servidores provenientes de devoluções de valores descontados a maior, tais como créditos tributários ou de contribuições ou, ainda, créditos diversos a receber (MANUAL SIAFI, 2009).

\footnotetext{
${ }^{11}$ Transação que permite registrar o comprometimento de despesa, bem como os casos em que se faça necessário o reforço ou a anulação desse compromisso.

${ }^{12}$ Transação que permite aos usuários do SIAFI, autorizados, a realizar a atualização da lista item empenho.
} 
Ocorre que no SIAFI, quando uma folha que possui créditos associados é paga, o documento de pagamento não registra o valor correspondente ao crédito na conta 29213.03.01 - CREDITO EMPENHADO A LIQUIDAR porque o mesmo já foi registrado anteriormente como pago. Assim, os documentos de pagamento ficam com um registro de valor orçamentário menor que o financeiro.

Por exemplo, conforme mostra a Figura 16, uma OB01 que está pagando a folha FL01 (que possui 500 registrado como crédito e 1000 registrado como despesa), terá 1.500 registrado como informação financeira e apenas 500 como informação orçamentária.

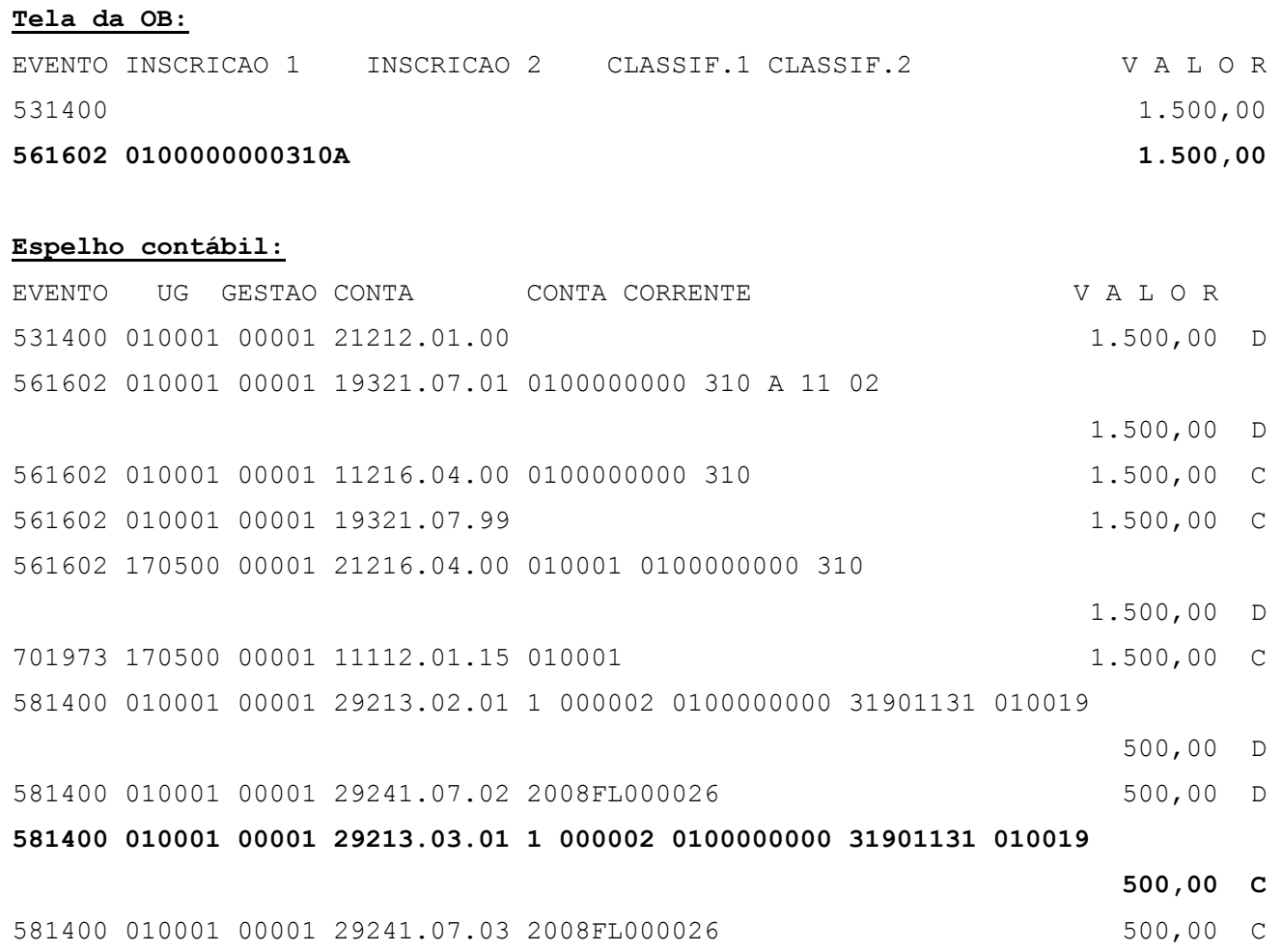

Figura 16 - Créditos da folha de pagamento

$\underline{O}$ ideal seria que contabilmente o SIAFI registrasse o cancelamento do pagamento realizado a maior (que gerará o crédito) de forma que o novo pagamento registre a informação orçamentária correspondente à sua despesa.

\subsection{Folha de pagamento - fonte de recursos}

O Documento Folha, até fevereiro de 2009, não realizava a verificação de consistência entre Fonte de Recursos financeira informada pelo usuário e a Fonte Orçamentária, o que 
pode produzir informações inconsistentes dependendo do enfoque orçamentário ou financeiro consultado no período de janeiro de 2008 a janeiro de 2009.

\subsection{Liquidação}

Como o documento NSs no SIAFI é utilizado para diversos registros automáticos tais como extinção, incorporação e transferência de saldos, acertos contábeis e integração de saldos de balanço, entre outros, para fins de informações sobre liquidação da despesa serão carregadas apenas as NSs geradas automaticamente pelo CPR.

Como no SIAFI ainda podem ocorrer liquidações através de documentos NL, estes também devem ser considerados. Optou-se por criar um contexto de análise específico para as NLs, conforme Apêndice A.

Dessa forma, o Valor liquidado será a soma dos valores das NSs e das NLs, conforme descrito no Apêndice B.

Vale observar que outras NSs deverão ser carregadas para alguns procedimentos específicos do SIAFI em que NSs são utilizadas para ajustes cambiais (ver item 4.10 Câmbio) e para registro de pagamentos, devoluções ou cancelamento, conforme descrito adiante. Nestes casos específicos, os documentos NSs serão carregados nas tabelas fato correspondente e não na tabela fato das NSs que registram a liquidação.

\subsection{Pagamento}

São considerados pagamentos os documentos OB, DAR, DARF, GPS, GRU e GFIP. E de forma a criar um conceito único de pagamento, facilitando o relacionamento entre as informações, optou-se por definir um atributo único chamado Pagamento e dele então especializar os demais. Como no SIAFI Gerencial já existe um parâmetro Tipo de Documento, que dentre eles estão também os tipos de OB, optou-se por manter a mesma classificação no atributo chamado Tipo de Pagamento. As informações comuns aos pagamentos são apenas o número, o tipo e a observação do documento. 
Para registrar o relacionamento entre os pagamentos e seus cancelamentos criou-se o Pagamento Referência, assim como o conceito de referência no documento empenho. Desta forma, todo documento quando é emitido é simultaneamente o Pagamento e o Pagamento Referência. Caso o pagamento seja cancelado, cria-se um registro em que o Pagamento Referência é o documento de cancelamento e o Pagamento é o documento que está sendo cancelado. A situação de Original ou Cancelamento é dada pela Espécie do Pagamento.

\subsection{Pagamento principal $x$ juros}

Os documentos DAR, DARF, GPS, GFIP, GRU possuem empenhos específicos para o pagamento do principal, multas ou juros e o Tipo Empenho Pagamento é o atributo que classifica estes empenhos. Assim, por exemplo, dado um DARF DF01 da UGA no valor de 1.000, referente ao empenho NE01, que foi pago com atraso e teve o empenho NE02 como referência ao pagamento dos juros de 100, temos que o valor total pago pelo DARF foi 1.100, sendo que a NE01 tem tipo Principal e a NE01 tem tipo juros, conforme mostra o Quadro 10.

\begin{tabular}{lcccc}
\hline UG & DARF & Empenho & Tipo NE Pagamento & Valor \\
\hline UGA & DF01 & NE01 & Principal & 1.000 \\
\hline UGA & DF01 & NE02 & Juros & 100 \\
\hline
\end{tabular}

Quadro 10 - Tipo NE Pagamento

\subsection{Pagamento Efetivo $x$ Data Saque}

A Data de Pagamento Efetivo é a data que corresponde ao saque na Conta Única do Tesouro. Para os pagamentos que são processados on-line pelo Sistema de Pagamentos Brasileiro (SPB), para as OBs intra SIAFI (tipo 10) e para os documentos de cancelamento total ou parcial a data de pagamento efetivo é D0 em relação à data de lançamento do documento. Para os demais pagamentos é $\mathrm{D}+1$.

A Data de Pagamento Efetivo deve ser calculada no momento da carga e conforme visto em 4.9 Barramentos é a base para o atributo Data. A Data de Pagamento Efetivo 
corresponde à mesma data utilizada para os cálculos das transações CAIXA $^{13}$ e CONCAIXA $^{14}$ do SIAFI.

O SIAFI Gerencial possui o parâmetro Data Saque, que também é um conta corrente no SIAFI, e que conceitualmente seria o correspondente à Data de Pagamento Efetivo, porém seu cálculo é baseado apenas no tipo de documento, não levando em conta o indicador on-line do SPB. Assim, divergências podem ocorrer em consultas realizadas no SIAFI Gerencial e no DW, sobretudo quando um tipo de pagamento é considerado $\mathrm{D}+1$ para o Data Saque, mas possui indicador on-line marcado no SIAFI e portanto é considerado D0 na Data de Pagamento Efetivo. Essas diferenças são comuns no final do mês, quando um pagamento é realizado no último dia do mês e é considerando ainda neste mês pela Data de Pagamento Efetivo e considerado no mês seguinte pela Data Saque.

É importante, portanto, que os usuários do DW tenham conhecimento da diferença de regra de negócio entre a Data Saque e Data de Pagamento Efetivo.

\subsection{Categoria de gasto}

A categoria de gasto é informada pelo usuário no CPR, mas a sua inclusão não é obrigatória no SIAFI. A partir de 2008 a categoria de gasto informada pelo usuário passou a ser registrada também na inscrição 1 das Ordens Bancárias, mas quando o usuário não a informa, no momento da montagem da $\mathrm{OB}$, como o CPR não possui a categoria de gasto, este a considera com base no Grupo de Despesa registrado no Empenho. Temos então o seguinte problema para a carga da categoria de gasto: se buscarmos no CPR teremos alguns valores nulos, se buscarmos na inscrição 1 da $\mathrm{OB}$ não teremos a informação nos documentos de exercícios anteriores a 2008.

$\underline{\mathrm{O} \text { ideal seria que fosse obrigatório para o usuário informar a categoria de gasto no }}$ CPR e que esta fosse validada de acordo com as informações do empenho correspondente. Isto resolveria a carga dos documentos a partir desta alteração, mas para os documentos já emitidos, a solução mais indicada é carregar com base no CPR e caso a informação esteja nula, buscar na OB ou realizar a mesma regra utilizada pelo CPR quando da montagem da OB.

\footnotetext{
${ }^{13}$ Transação que permite consultar a movimentação diária de recursos na Conta Única do Tesouro Nacional de forma discriminada, bem como o saldo do dia e até o dia ou do mês e até o mês.

14 Nova transação CAIXA.
} 


\subsection{NS de cancelamento}

Uma boa parte dos documentos de cancelamento de pagamentos é realizada de forma automática pelo SIAFI no processamento batch das informações que retornam das instituições financeiras. Quando, por exemplo, um banco retorna a informação de conta corrente inexistente, o SIAFI gera um documento cancelando o pagamento original. Ocorre que, por motivos internos ao SIAFI, no caso específico de Ordens Bancárias, quando este documento de cancelamento não consegue ser gerado, em seu lugar é emitida um NS de cancelamento. Neste caso, então, existem documentos do tipo NSs cancelando OBs.

$\underline{\mathrm{O} \text { ideal seria que no SIAFI o documento de cancelamento emitido fosse sempre uma }}$ Ordem Bancária, de forma que se mantivesse a correta correspondência entre os documentos Original e de Cancelamento.

Mas, para que estes cancelamentos sejam considerados no DW mantendo-se a compatibilidade de dados com o sistema fonte, a solução mais adequada é carregar estas NSs como se fossem Ordem Bancárias de cancelamento, assim, caso a OB01 da UGA seja cancelada pela NS01 teremos os registros exibidos no Quadro 11.

\begin{tabular}{lcccc}
\hline UG & Pagamento & Pagamento Ref. & Espécie Pgto & Valor \\
\hline UGA & OB01 & OB01 & Original & 1.000 \\
\hline UGA & OB01 & NS01 & Cancelamento & 1.000 \\
\hline \multicolumn{5}{r}{ Quadro 11 - Cancelamento por NS } \\
\end{tabular}

\subsection{NS de estorno}

As devoluções de recursos no SIAFI são realizadas por meio de GRUs emitidas pelas respectivas Unidades Gestoras. Quando se referem a despesas do exercício corrente são realizadas no CPR via documento hábil do tipo GD - RESTITUICAO DE DESPESAS P/VALORES A DEBITAR e a GRU é o documento de origem do procedimento. Neste caso é gerada uma NSs de estorno e um lançamento na conta contábil Pagamentos Efetuados (193210701) e não há no CPR qualquer relacionamento com a ordem bancária que está sendo estornada. 
Quando se referem a despesas de exercícios anteriores, o procedimento não é realizado via CPR, mas assim como nas despesas do exercício corrente, uma NS de estorno é emitida e é feito um lançamento na conta Pagamentos Efetuados.

$\underline{\mathrm{O} \text { ideal seria que para despesas do exercício corrente o } \mathrm{CPR} \text { registrasse o número da }}$ Ordem Bancária que está sendo estornada e que o estorno fosse realizado via uma OB de estorno, mantendo a lógica de cancelamento de OBs.

Para despesas de exercícios anteriores, o ideal seria que o procedimento fosse realizado no CPR por um documento hábil específico (diferente do GD). Mesmo que este procedimento gerasse uma NS de estorno, assim seria mais simples buscar estes casos a partir do tipo de documento hábil.

Mas, para solucionar o problema dos estornos que já existem hoje no SIAFI, a solução mais adequada é ler a conta contábil Pagamentos Efetuados e carregar para o DW as NSs que foram lançadas nesta conta. Para os estornos de despesas do exercício pode-se buscar a CONMOVOC o empenho referente e carregar Fonte de Recursos, Vinculação e Categoria de Gasto a partir do conta corrente lançado. Para os exercícios anteriores, como não há informação do empenho, apenas as informações do conta corrente devem ser carregadas.

\subsection{Lista de credores}

Quando a OB possui lista de credores, o seu favorecido é uma instituição bancária e os credores estarão registrados numa lista de credores. No modelo proposto, a identificação dos credores está no atributo Favorecido Lista. Desta forma é possível recuperar os valores pagos para cada um.

Porém, não é possível relacionar os credores com as informações orçamentárias e financeiras porque na estrutura das Ordens Bancárias não há esta associação de informações.

Uma solução seria associar, no momento da carga para o DW, o credor com todas as informações orçamentárias e financeiras da $\mathrm{OB}$, mas isto não é possível porque as OBs podem ter mais de uma linha de empenho (exemplo na Figura 17) ou mais de uma linha de fonte/vinculação, o que torna impossível determinar a qual destas informações o credor está associado. 


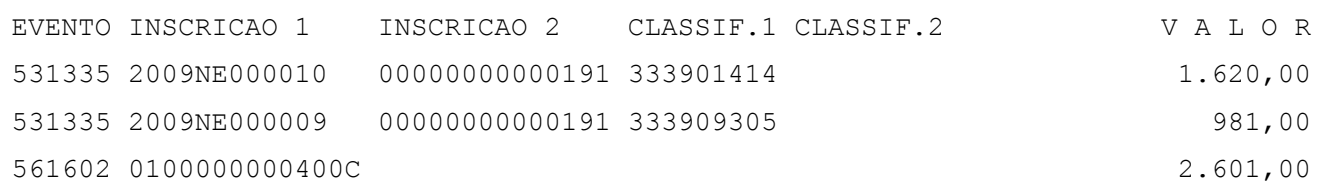

Figura 17 - OBs com mais de um empenho

$\underline{\mathrm{O} \text { ideal seria que a estrutura das OBs no SIAFI registrasse o relacionamento entre as }}$ informações orçamentárias e financeiras para cada credor.

\subsection{Cancelamento parcial de OBs}

O cancelamento parcial de OBs ocorre quando o a instituição bancária não consegue realizar o depósito bancário para o credor. O banco, então, devolve a informação para o SIAFI que cancela apenas o valore referente ao credor e não a OB completamente.

Ocorre que nestes casos, a montagem da OB de cancelamento não reflete o estorno do valor referente ao empenho. A Figura 18, por exemplo, exibe uma OB original cuja inscrição 1 possui o 2009NE000519, mas a sua OB de cancelamento, na Figura 19, não possui vínculo com o empenho, e conseqüentemente com as informações orçamentárias.

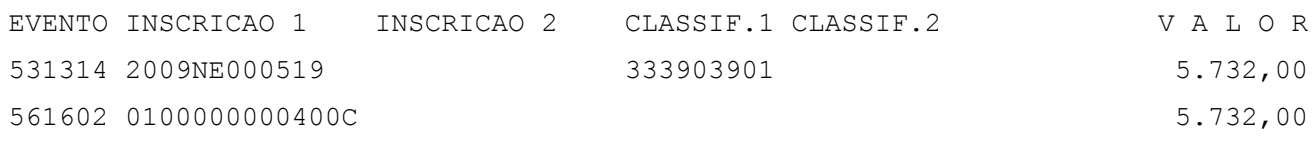

Figura 18 - OB original

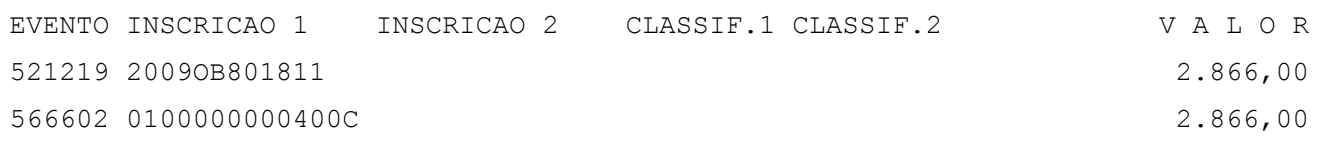

Figura 19 - OB de cancelamento

Cabe salientar que em termos contábeis, o estorno foi realizado completamente, apenas o documento OB não reflete em sua estrutura este estorno realizado.

Além disso, há casos em que existem mais de uma linha de empenho (Figura 20) ou mais uma linha de fonte/vinculação/categoria de gasto e não é possível se identificar no SIAFI a qual linha o estorno se refere. 


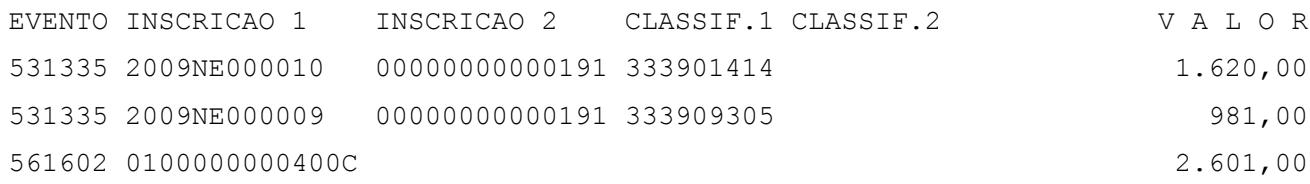

Figura 20 - OB com mais de um empenho

$\underline{O}$ ideal seria que, além da existência da associação entre os favorecidos e as informações orçamentárias e financeiras (conforme sugerido em 4.30 Lista de credores), a OB de cancelamento registrasse em sua estrutura o estorno referente ao empenho.

A solução de contorno encontrada para este caso foi carregar as OBs de cancelamento parcial com os mesmos dados da OB original, alterando-se apenas o valor cancelado.

Assim, por exemplo, para uma OB01 no valor de 1.000 que tenha 100 cancelado pela OB02 teríamos como mostrado no Quadro 12.

\begin{tabular}{cccccccc}
\hline UG & Pagamento & $\begin{array}{c}\text { Pagamento } \\
\text { Ref }\end{array}$ & Espécie Pgto & Empenho & $\begin{array}{c}\text { Fonte de } \\
\text { Recurso }\end{array}$ & Vinculação & Valor \\
\hline UGA & OB01 & OB01 & Original & NE01 & - & - & 1.000 \\
\hline UGA & OB01 & OB01 & Original & - & F1 & V1 & 1.000 \\
\hline UGA & OB01 & OB02 & Cancelamento & NE01 & - & - & 100 \\
& & Parcial & & & \\
\hline UGA & OB01 & OB02 & Cancelamento & - & F1 & V1 & 100 \\
& & Parcial & & & & \\
\hline
\end{tabular}

Quadro 12 - Carga de OB com mais de um empenho

\subsection{Transferências constitucionais}

As transferências constitucionais relativas ao Fundo de Participação dos Estados e do Distrito Federal (FPE), ao Fundo de Participação dos Municípios (FPM), ao Fundo de Compensação pela Exportação de Produtos Industrializados (FPEX), ao Fundo de Manutenção e Desenvolvimento da Educação Básica e de Valorização dos Profissionais da Educação (Fundeb), entre outros, são repassadas decendialmente pelo Tesouro Nacional aos Estados e Municípios.

Os percentuais de distribuição são calculados pelo Tribunal de Contas da União (TCU) e a transferência dos recursos aos Estados e Municípios é realizada pelo Banco do Brasil 
(BB). No momento do repasse o Tesouro não conhece o percentual exato para cada Estado e Município, por isso gera uma $\mathrm{OB}$ no valor total para que o BB realize a distribuição.

Essa $\mathrm{OB}$, portanto, não possui a informação orçamentária correspondente, que será lançada posteriormente quando do recebimento do retorno do BB com a exata distribuição realizada. Nesse momento, então, são geradas automaticamente NSs registrando os valores e fazendo as devidas correspondências com os empenhos.

Neste caso temos, então, que as informações orçamentárias dos pagamentos estão registradas em Notas de Sistema.

$\underline{\text { O ideal seria que todo o procedimento de transferência fosse de forma "linkada", do }}$ empenho ao pagamento, de forma a recuperar no pagamento (OB), inclusive o valor repassado a cada Estado e Município. Este procedimento poderia ser realizado no CPR a partir de um documento hábil específico para tal.

Mas, como solução de contorno, as NSs podem ser carregadas como se fossem pagamentos e assim as informações orçamentárias podem ser recuperadas. Neste caso, são carregadas as NSs cujo evento seja 541128 - APROPRIACAO AUTOMATICA DE DESPESA A TRANSFERENCIA CONSTITUCIONAL A ESTADOS, DF E MUNICIPIOS COM BASE NA LIBERACAO DO TESOURO NACIONAL.

\subsection{Empenho do Pagamento}

Existem alguns eventos no SIAFI que não exigem que a Nota de Empenho seja informada no pagamento. Isto faz com que se perca a correspondência entre as informações orçamentárias e financeiras.

$\underline{\text { O ideal seria que o SIAFI garantisse completamente o vínculo entre as informações }}$ orçamentárias e financeiras.

\subsection{Informação orçamentária $x$ financeira}

A principal dificuldade encontrada na confecção do modelo de dados foi o fato das Ordens Bancárias no SIAFI não possuírem o cruzamento dos dados orçamentários e 
financeiros. A arquitetura do documento $\mathrm{OB}$, diferentemente dos demais pagamentos, estabelece que os dados orçamentários (registrados no empenho) e os dados financeiros (registrados nas informações de fonte de recursos, vinculação de pagamento e categoria de gasto) sejam lançados em linhas e eventos distintos.

Nos documentos DAR, DARF, GPS, GFIP e GRU, os dados orçamentários estão associados em uma linha única, conforme visto na Figura 21.

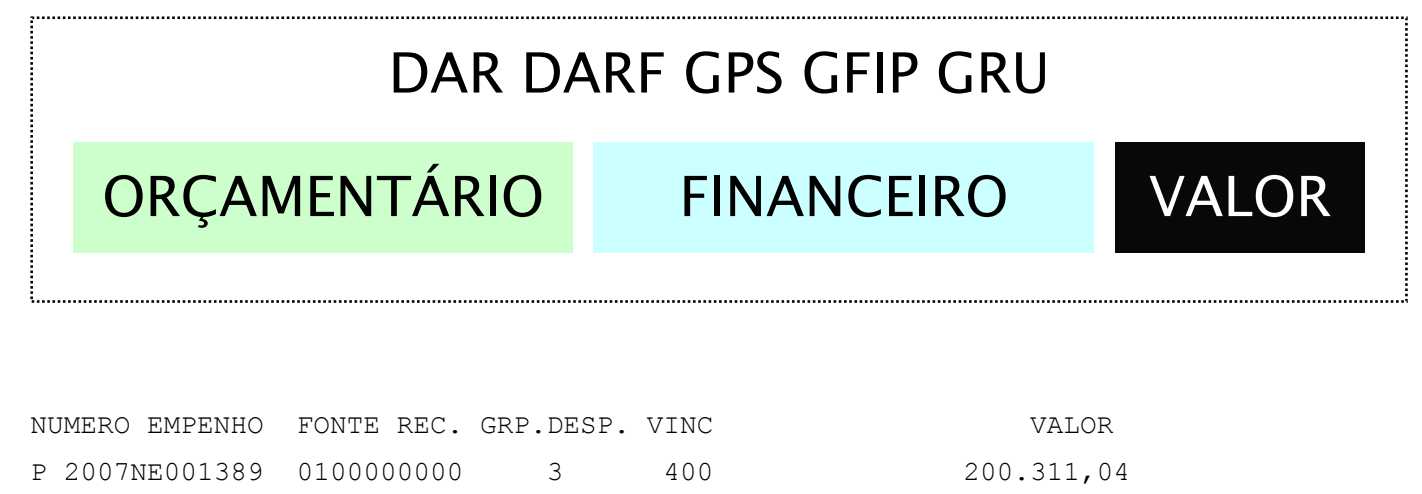

Figura 21 - Cruzamento de dados orçamentários e financeiros

Já nas OBs, estes valores estão em linhas distintas e não podem ser cruzados (Figura 22) porque em algumas situações pode-se ter vários empenhos para uma única informação financeira (Figura 24), ou um único empenho para várias informações financeiras (Figura 25) ou ainda vários empenhos e várias informações financeiras (Figura 26). Nestes casos não é possível determinar como estas linhas se relacionam. Podem acontecer casos, ainda, que uma OB tenha apenas a informação do empenho (Figura 27) ou que uma OB tenha apenas as informações financeiras (Figura 28).

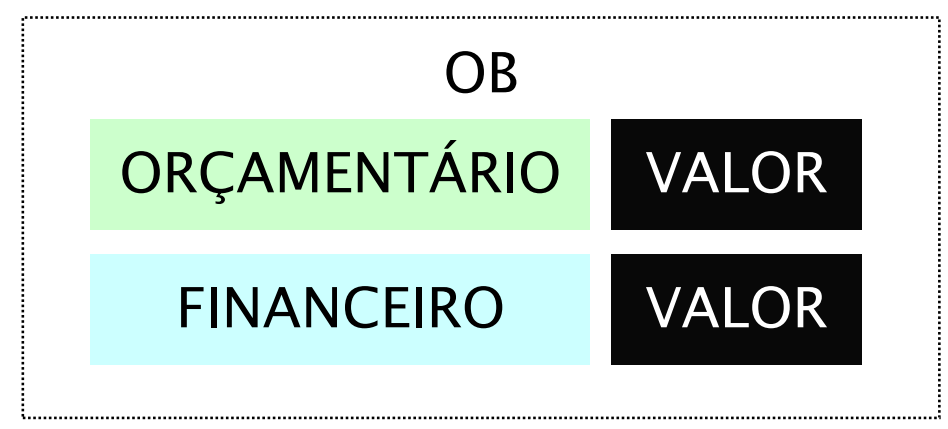

Figura 22 - Falta de cruzamento de dados orçamentários e financeiros

$\begin{array}{llll}\text { EVENTO INSCRICAO } 1 & \text { INSCRICAO 2 } & \text { CLASSIF.1 CLASSIF.2 } & \text { V A L O R } \\ 5313142007 \text { NE000501 } & 333903958 & 20.232,93 \\ 561602 & 0100000000400 \mathrm{C} & & 20.232,93\end{array}$

Figura 23 - Exemplo de linhas da OB 


$\begin{array}{llll}\text { EVENTO INSCRICAO 1 INSCRICAO 2 } & \text { CLASSIF.1 CLASSIF.2 } & \text { V A L O R } \\ 5313142007 \text { NE000501 } & 333903958 & 20.000,00 \\ 5313142007 \text { NE000502 } & 333903958 & 10.232,93 \\ 561602 \text { 0100000000400C } & & 20.232,93\end{array}$

Figura 24 - OB com mais de um empenho

$\begin{array}{llll}\text { EVENTO INSCRICAO } 1 & \text { INSCRICAO 2 } & \text { CLASSIF.1 CLASSIF.2 } & \text { V A L O R } \\ 5313142007 \text { NE000501 } & 333903958 & 20.232,93 \\ 5616020100000000400 \mathrm{C} & & 20.000,00 \\ 5616020100000000500 \mathrm{C} & & 10.232,93\end{array}$

Figura 25 - OB com mais uma informação financeira

$\begin{array}{llll}\text { EVENTO INSCRICAO } 1 & \text { INSCRICAO 2 } & \text { CLASSIF.1 CLASSIF.2 } & \text { V A L O R } \\ 5313142007 \mathrm{NE} 000501 & 333903958 & 10.000,00 \\ 5313142007 \mathrm{NE} 000501 & 333903958 & 10.232,93 \\ 5616020100000000400 \mathrm{C} & & 10.000,00 \\ 561602 \text { 0100000000400C } & & 10.232,93\end{array}$

Figura 26 - OB com vários empenhos e vários dados financeiros

$\begin{array}{llll}\text { EVENTO INSCRICAO } 1 & \text { INSCRICAO 2 } & \text { CLASSIF.1 CLASSIF.2 } & \text { V A L O R } \\ 5313142007 N E 000501 & & 333903958 & 20.232,93\end{array}$

Figura 27 - OB com apenas dados orçamentários

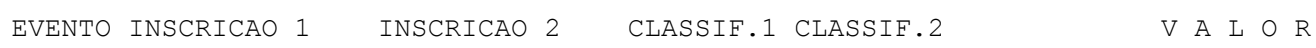

Figura 28 - OB com apenas dados financeiros

Quando se carrega as linhas da OB tal qual estão registradas no SIAFI, ocorre duplicação de dados e conseqüentemente a duplicação do valor da OB.

$\underline{O}$ ideal seria que a OB registrasse esse cruzamento de informações orçamentárias e financeiras, assim como nos outros documentos. Mas, a implementação desta solução implicaria na redefinição da arquitetura da OB.

Uma outra solução em curto prazo é registrar esse cruzamento de informações numa conta contábil de controle que teria como conta corrente: número do empenho + grupo de despesa + fonte financeira + vinculação de pagamento + categoria de gasto. Os lançamentos nesta conta devem ser disparados por um evento de máquina associado à emissão das OBs. Os cancelamentos, da mesma forma, devem ser registrados nesta conta.

Vale salientar que Grupo de Despesa e Fonte de Recursos são informações que constam no empenho e por isso são redundantes. Porém, o SIAFI permite a entrada manual destas informações e por isso optou-se por mantê-las (ver 4.17 Folha de pagamento). 
As OBs seriam carregadas então a partir da leitura dos lançamentos nesta conta e não pela tabela de OB.

Cabe salientar que esta solução deve ser implantada no início do exercício para evitar inconsistência nos dados.

Mas, ainda assim, os exercícios anteriores à implementação da conta contábil necessitam de uma solução que não permita a duplicação dos dados.

Uma solução é criar indicadores que marquem as linhas como sendo de informações orçamentárias ou financeiras (ou as duas, no caso dos outros documentos) e criar métricas específicas para o orçamento e para o financeiro. O usuário, então, decide sob qual enfoque deseja obter os dados. A Figura 29 exibe como deve ser preenchido o ind_enfoque para cada situação descrita nas Figura 23 a Figura 28.

\begin{tabular}{|c|c|c|c|c|c|c|c|c|c|}
\hline NUMERO & EMPENHO & FONTE & REC. GRP. & DESP. & VINC & & VALOR & \multicolumn{2}{|c|}{ IND_ENFOQUE } \\
\hline P 20071 & NE001389 & 01000 & 00000 & 3 & 400 & & $200.311,04$ & $\mathrm{COF}$ & \\
\hline EVENTO & INSCRICAO & 01 & INSCRICAO & 2 & CLASSIF. 1 & CLASSIF. 2 & & $V A L O R$ & IND_ENFOQUE \\
\hline 531314 & $2007 \mathrm{NE} 000$ & 0501 & & & 333903958 & & & $20.232,93$ & $\mathrm{CORC}$ \\
\hline 561602 & 010000000 & $00400 \mathrm{C}$ & & & & & & $20.232,93$ & CFIN \\
\hline EVENTO & INSCRICAO & 01 & INSCRICAO & 2 & CLASSIF. 1 & CLASSIF. 2 & & $\mathrm{~V} A \mathrm{~A} \bigcirc \mathrm{R}$ & IND_ENFOQUE \\
\hline 531314 & $2007 \mathrm{NE} 000$ & 0501 & & & 333903958 & & & $20.000,00$ & $\mathrm{CORC}$ \\
\hline 531314 & $2007 \mathrm{NE} 000$ & 0502 & & & 333903958 & & & $10.232,93$ & $\mathrm{CORC}$ \\
\hline 561602 & 010000000 & $00400 \mathrm{C}$ & & & & & & $20.232,93$ & CFIN \\
\hline EVENTO & INSCRICAO & 1 & INSCRICAO & 2 & CLASSIF. 1 & CLASSIF. 2 & & $\mathrm{~V} A \mathrm{~A} \bigcirc \mathrm{R}$ & IND_ENFOQUE \\
\hline 531314 & $2007 \mathrm{NE} 000$ & 0501 & & & 333903958 & & & $20.232,93$ & $\mathrm{CORC}$ \\
\hline 561602 & 010000000 & $00400 \mathrm{C}$ & & & & & & $20.000,00$ & CFIN \\
\hline 561602 & 010000000 & $00500 \mathrm{C}$ & & & & & & $10.232,93$ & CFIN \\
\hline EVENTO & INSCRICAO & 1 & INSCRICAO & 2 & CLASSIF. 1 & CLASSIF. 2 & & $\mathrm{~V} A \mathrm{~L} O \mathrm{R}$ & IND_ENFOQUE \\
\hline 531314 & $2007 \mathrm{NE} 000$ & 0501 & & & 333903958 & & & $10.000,00$ & $\mathrm{CORC}$ \\
\hline 531314 & $2007 \mathrm{NE} 000$ & 0501 & & & 333903958 & & & $10.232,93$ & CORC \\
\hline 561602 & 010000000 & $00400 \mathrm{C}$ & & & & & & $10.000,00$ & CFIN \\
\hline 561602 & 010000000 & $00400 \mathrm{C}$ & & & & & & $10.232,93$ & CEIN \\
\hline EVENTO & INSCRICAO & 1 & INSCRICAO & 2 & CLASSIF. 1 & CLASSIF. 2 & & $V A L O R$ & IND_ENFOQUE \\
\hline 531314 & $2007 \mathrm{NE} 000$ & 501 & & & 333903958 & & & $20.232,93$ & $\mathrm{SORC}$ \\
\hline EVENTO & INSCRICAO & 1 & INSCRICAO & 2 & CLASSIF. 1 & CLASSIF. 2 & & $\mathrm{~V} A \mathrm{~A} \bigcirc \mathrm{R}$ & IND_ENFOQUE \\
\hline 561602 & 0100000000 & $00400 \mathrm{C}$ & & & & & & $20.232,93$ & SFIN \\
\hline
\end{tabular}




\begin{tabular}{ll}
\hline Ind & Descrição \\
Enfoque & \\
\hline COF & Registro com informação orçamentária e financeira na mesma linha \\
\hline CORC & Registro com informação orçamentária, mas de uma OB onde consta informação financeira também \\
\hline CFIN & Registro com informação financeira, mas de uma OB onde consta informação orçamentária também \\
\hline SORC & Registro com informação orçamentária de uma OB onde não consta informação financeira \\
\hline SFIN & Registro com informação financeira de uma OB onde não consta informação orçamentária \\
\hline
\end{tabular}

\section{Figura 29 - Indicador de enfoque}

Para o enfoque orçamentário, por exemplo, devem-se verificar os registros cujo ind_enfoque seja igual a CORC ou SORC ou COF.

Mas para que seja possível o uso de expressões do tipo Grupo de Despesa $=1$ ou Vinculação $=310$, misturando-se critérios orçamentários e financeiros, deve-se prever que caso a primeira condição não retorne registros, a segunda deve ser verificada também. Este caso trata de utilização dos enfoques numa só consulta e para isso o usuário deve decidir qual deve ser verificado primeiro.

Assim, a métrica valor pago com enfoque orçamentário deve verificar inicialmente se a consulta retorna valores para os registros cujo ind_enfoque seja orçamentário. Se não, a métrica deve verificar se registros são retornados para o ind_enfoque financeiro. Ao final, os registros retornados são somados aos registros cujo ind_enfoque seja orçamentário e financeiro. As fórmulas das métricas encontram-se detalhadas no Apêndice B.

\subsection{Vinculação de pagamento}

A vinculação de pagamento foi criada no SIAFI com o intuito de possibilitar a vinculação entre as informações orçamentárias e financeiras. Mas, a vinculação é informada pelo usuário e não há validação da mesma com os dados orçamentários.

$\underline{O}$ ideal seria que o SIAFI, no momento da realização, efetuasse validação de consistência entre a vinculação informada pelos usuários e os dados orçamentários correspondentes.

Esta limitação não pode ser tratada pelo modelo, e há possibilidade de consultas apresentarem valores diferentes dependendo do enfoque escolhido. Por exemplo, uma 
consulta que utilize como filtro o Grupo de Despesa igual a 1 (pessoal) pode dar um valor diferente se utilizar a Vinculações de Pagamento de pessoal.

\subsection{Métricas de saldo}

Em geral, as consultas realizadas no SIAFI e no SIAFI Gerencial são de saldo das contas. De forma a reproduzir no modelo proposto a possibilidade de consultas acumuladas, as principais métricas trazem a opção de valor acumulado anual. Assim, o "Valor empenhado até o mês", por exemplo, é o valor acumulado dos empenhos até um dado mês, diferentemente do Valor Empenhado, cujo valor se refere apenas ao mês. Vale destacar que, apesar da base conter diversos exercícios, a métrica acumulada é em relação ao exercício e não ao acumulado de toda a base de dados. 


\section{DISCUSSÃO DOS RESULTADOS}

Como afirmam Bastos et al. (2004), nem sempre é possível sanar as limitações intrínsecas de cada um dos fornecedores de dados ao DW. Limitações, que podem ser derivadas da arquitetura do sistema, da tecnologia, de procedimentos ou de alimentação dos dados, quando não podem ser resolvidas no sistema de origem, são de fato herdadas pelo sistema gerencial. Ainda assim, quando resolvidas nos sistemas fonte, os dados anteriores ao ajuste continuarão sofrendo a limitação.

O presente trabalho trouxe como contribuição, tão importante quanto à proposição do modelo, a identificação das limitações no sistema fonte (SIAFI) que impactam a implantação de uma base de dados de informações gerenciais.

A maior limitação encontrada foi a impossibilidade de cruzamento de dados entre as informações orçamentárias e financeiras, sobretudo por causa da arquitetura lógica da OB e dos pagamentos do novo Documento Folha. Também, foi identificado que o documento NS realiza diversos acertos contábeis que algumas vezes não podem ser rastreados pelas rotinas automáticas de extração.

A implantação do cruzamento de informações orçamentárias e financeiras a partir de uma conta contábil apresenta-se como uma boa solução a curto prazo, além de também impactar positivamente (ajudando na resolução) de outras limitações, como o complexo registro dos dados da Folha de pagamento.

Já para se evitar a utilização das NSs para diversos fins, seria necessária uma reforma estrutural no SIAFI, que certamente traria enormes ganhos de controle e rastreabilidade dos dados, mas cujo custo/benefício deveria ser amplamente analisado.

Mas, mesmo diante de todas as limitações analisadas, o presente estudo constatou a viabilidade da implantação de uma solução baseada no modelo dimensional proposto.

O modelo proposto está preparado para possibilitar a saída de consultas tais como a listada na Figura 30 e para:

- Analisar detalhadamente cada documento

- Realizar o acompanhamento dos créditos orçamentários, dos empenhos, das liquidações e dos pagamentos utilizando como critérios as classificações institucional, funcional, programática, econômica ou financeira.

- Obter informações de credores e de faturas

- Realizar o acompanhamento da execução do PPI e PAC 
- Realizar acompanhamento da execução da dívida pública

- Realizar o acompanhamento das despesas com transferências constitucionais

- Acompanhar a execução da Folha de Pagamento analisando ora o Documento Folha, ora os pagamentos realizados.

- Acompanhar a execução orçamentária e financeira sob a ótica de caixa.

\begin{tabular}{|l|l|l|l|l|l|l|c|c|c|c|}
\hline \multirow{2}{*}{ ÓRGÃO } & $\begin{array}{c}\text { DOTAÇÃO } \\
\text { INICIAL }\end{array}$ & $\begin{array}{c}\text { CRÉDITOS } \\
\text { ADICIONAIS }\end{array}$ & $\begin{array}{c}\text { VALOR } \\
\text { EMPENHADO }\end{array}$ & $\begin{array}{c}\text { VALOR } \\
\text { LIQUIDADO }\end{array}$ & $\begin{array}{c}\text { VALOR } \\
\text { PAGO }\end{array}$ & $\begin{array}{c}\text { A } \\
\text { PAGAR }\end{array}$ & $\begin{array}{c}\text { RP } \\
\text { INSCRITO }\end{array}$ & $\begin{array}{l}\text { RP INSC. } \\
\text { LÍQUIDO }\end{array}$ & $\begin{array}{c}\text { RP } \\
\text { PAGO }\end{array}$ \\
\hline ÓRG A & $\cdots$ & $\cdots$ & $\cdots$ & $\cdots$ & $\cdots$ & $\cdots$ & $\cdots$ & $\cdots$ & $\cdots$ \\
\hline ÓRG B & $\cdots$ & $\cdots$ & $\cdots$ & $\cdots$ & $\cdots$ & $\cdots$ & $\cdots$ & $\cdots$ & $\cdots$ \\
\hline$\cdots$ & $\cdots$ & $\cdots$ & $\cdots$ & $\cdots$ & $\cdots$ & $\cdots$ & $\cdots$ & $\cdots$ & $\cdots$ \\
\hline
\end{tabular}

Figura 30 - Exemplo de consulta a ser respondida pelo modelo

Além disso, o modelo responde a perguntas tipicamente gerenciais, como:

- Quantos empenhos foram emitidos até determinada data por cada Órgão Superior? Quantos empenhos foram emitidos pelo Ministério da Ciência e Tecnologia? Quanto este valor representa percentualmente em relação os empenhos emitidos por todos os Órgãos Superiores?

- Qual o órgão superior que teve o maior valor de inscrição em RP processado em um determinado exercício financeiro?

- Qual o órgão superior que menos inscreveu RP de exercícios anteriores?

- Quanto foi pago de autorização de viagens (tipo doc hábil = AV) por cada órgão superior em determinado período?

- Qual a diferença percentual entre os valores pagos de investimentos do Ministério dos Transportes num mês do exercício atual em relação ao mesmo mês do exercício anterior?

- Faça um gráfico da evolução dos valores pagos de folha de pagamento do Senado Federal nos últimos 4 meses.

- Quais os documentos que pagaram o documento folha FL000055 da Câmara dos Deputados?

- Quais as vinculações de pagamento que pagaram na fonte 100 num determinado mês?

- Quais programas de trabalho da função Educação pagaram mais que R\$1.000.000 em mês? 
- Num determinado mês, quais os CNPJs receberam valores superiores a R\$ 10.000.000,00 em investimentos? 


\section{CONCLUSÃO}

Ao apresentarmos o modelo dimensional atingimos o objetivo proposto. Porém, consideramos que a maior contribuição deste trabalho foi a análise das limitações encontradas no SIAFI que impactam a implementação de um sistema de informações gerenciais baseado na tecnologia data warehousing.

Diante das diversidades de situações nos sistemas fontes e suas peculiaridades, muitas vezes são criados artifícios próprios para solução de problemas, muitas vezes até descaracterizando os conceitos aprendidos. E este trabalho se propôs a discutir possíveis adaptações, sempre com o foco oferecer um modelo o mais próximo possível dos conceitos já utilizados pelos usuários do SIAFI, de forma transparente para estes, evitando assim resistências no uso de uma nova abordagem tecnológica.

Sabe-se que o quanto mais intuitivo é o sistema informático, mais sucesso este terá frente aos usuários, e modelar um data warehouse com este foco, é um desafio a mais.

Cabe ressaltar que algumas soluções poderiam ter sido implementadas através das métricas, mas isso exigiria a utilização de ferramenta OLAP capaz de suportar métricas mais complexas. Optou-se por resolver todas as dificuldades a partir do modelo dimensional, evitando-se a dependência de qualquer ferramenta para implementação do modelo.

Não obstante, é importante destacar que o modelo dimensional foi proposto pensandose em sua implementação em uma ferramenta OLAP baseada num data warehouse.

Uma parte deste trabalho já se encontra validada e implementada em um Data Warehouse chamado DW Pagamento Efetivo, utilizado pela Secretaria do Tesouro Nacional.

Dando continuidade à proposta de integração de dados a partir dos documentos do SIAFI, vislumbra-se a possibilidade de interligação com outros temas como convênios, dívida pública, compras e contratações.

As compras e contratações efetuadas pela Administração Pública Federal são registradas no Sistema Integrado de Administração de Serviços Gerais (SIASG) através de contratos cadastrados neste sistema.

Os convênios podem ser recuperados do Sistema de Gestão de Convênio (SICONV) ou do módulo de convênios do SIAFI.

O ponto de interface dos contratos e dos convênios com o modelo dimensional proposto é o Empenho. 
Por fim, desejamos que este trabalho possa contribuir na elaboração de um sistema de informações gerenciais e nas discussões de aperfeiçoamento do SIAFI como provedor destas informações. 


\section{REFERÊNCIAS}

ALBUQUERQUE, C.M. et al. Gestão de Finanças Públicas. 2. ed. Brasília, 2008.

BASTOS A.B. et al. Informação gerencial no orçamento público do Brasil. Congreso Internacional del CLAD sobre la Reforma del Estado y de la Administración Pública, 9., Madrid, 2004. Anais... Madrid, España, 2-5 nov., 2004.

BRASIL. Decreto-Lei n. 200, de 25 de fevereiro de 1967. Dispõe sobre a organização da Administração Federal e estabelece diretrizes para a reforma administrativa e dá outras providências.

BRASIL. Contas Abertas, 2009. Disponível em: < http://contasabertas.uol.com.br $>$. Acesso em: 14 fev. 2009.

BRASIL. Manual SIAFI, 2009. Disponível em: $<$ http://manualsiafi.tesouro.fazenda.gov.br $>$. Acesso em: 14 fev. 2009.

BRASIL. Portal da Transparência, 2009. Disponível em:

$<$ http://www.portaltransparencia.gov.br>. Acesso em: 14 fev. 2009.

BRASIL. PPA 2008-2011, 2009. Disponível em:

http://www.planejamento.gov.br/noticia.asp? $\mathrm{p}=\operatorname{not} \& \operatorname{cod}=191 \& \mathrm{cat}=155 \& \mathrm{sec}=10$

BRASIL. Secretaria do Tesouro Nacional, 2009. Disponível em:

$<$ www.tesouro.fazenda.gov.br>. Acesso em: 14 fev. 2009.

BRASIL. Siga Brasil, 2009. Disponível em:

$<$ http://www9.senado.gov.br/portal/page/portal/orcamento_senado/SigaBrasil $>$. Acesso em: 14 fev. 2009.

CASTRO, D.P; GARCIA, L.M. Reformulação das finanças públicas no Brasil. In:

Contabilidade Pública no Governo Federal. São Paulo: Atlas, 2004.

GODOY, Arilda Schmidt. Uma revisão histórica dos principais autores e obras que refletem esta metodologia de pesquisa em Ciências Sociais. Revista de Administração de Empresas, São Paulo, v. 35, n. 2, p. 57-63 mar/abr. 1995.

GONZAGA, T. S. Uma metodologia para o desenvolvimento de instrumentos de análise multidimensional da informação em projetos de governo eletrônico voltado ao cidadão. 2005. 130f. Dissertação (Pós-Graduação em Engenharia de Produção) - Universidade Federal de Santa Catarina, Florianópolis, 2005.

GUIMARÃES, Klícia Maria Silva. Uma proposta de modelo gerencial para administração pública: caso Brasil. 2003. 308 f. Tese (Doutorado em Economia y Empresa) - Curso de Economia y Empresa, Universitat de les Illes Balears, Palma, Illes Balears, 2003.

MACHADO, F. N. R. Projeto de Data Warehouse: uma visão multidimensional. São Paulo: Érica, 2000. 
MANFRINATO, A. D. Análise da implantação do sistema de planejamento e execução orçamentária do Exército Brasileiro - um estudo de caso. 2002. 78f. Dissertação (PósGraduação em Engenharia de Produção) - Universidade Federal de Santa Catarina, Florianópolis, 2002.

NÓBREGA, R. G. Cenários para a tecnologia de Data Warehousing no Serpro. Monografia CEIC-MCT/INT. CNPq/IBICT. UFRJ/ECO. Brasília, 1999.

O`BRIEN, J. A. Sistemas de informações e as decisões gerenciais na era da internet. Tradução Célio Knipel Moreira e Cid Knipel Moreira. 2. ed. São Paulo: Saraiva, 2004.

RABELLO, F.L.P. Alternativas tecnológicas ao aprimoramento da governança e da transparência na Administração Pública. 2006. 79f. Trabalho de Conclusão de Curso (PósGraduação) - Universidade de Brasília, Faculdade de Economia, Administração, contabilidade e Ciência da Informação, 2006

REZENDE, D.A; GUAGLIARDI, J.A. Sistemas de informação e de conhecimentos para contribuir na gestão municipal. Produto \& Produção, vol. 8, n. 3, p. 45-61, out. 2005.

SILVA, R.A. et al. A contabilidade governamental e os sistemas de informações gerenciais do governo federal brasileiro como instrumentos de controle social: a disponibilização das informações orçamentárias e financeiras via internet. Revista Universo Contábil, Blumenau, v. 3, n. 2, p. 73-86 maio/ago. 2007

SOUZA, A. A.; PASSOLONGO, Cristiani. Avaliação de sistemas de informações contábeis: estudos de casos múltiplos. UnB Contábil, v. 8, n. 2, p. 177-205, jul./dez. 2005.

VALENTE, A.P.M.A; DUMONT, L.M.M. Controle público e orçamento federal: avaliando o papel do SIAFI. Revista Informática Pública, Belo Horizonte, v. 5, n. 1, p. 49-64, jun. 2003 


\section{APÊNDICE A - MODELO DIMENSIONAL - CONTEXTOS DE ANÁLISE}

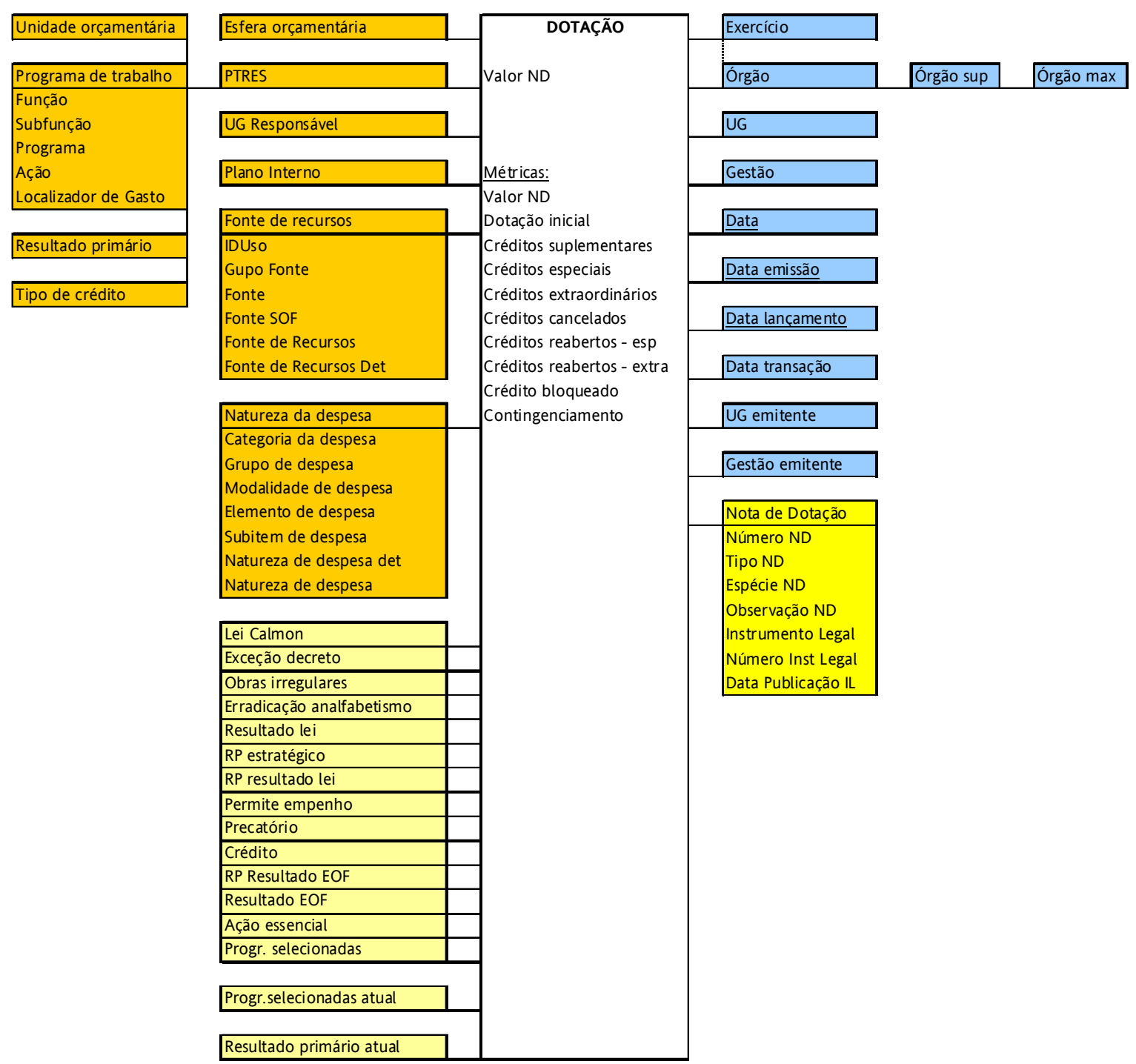




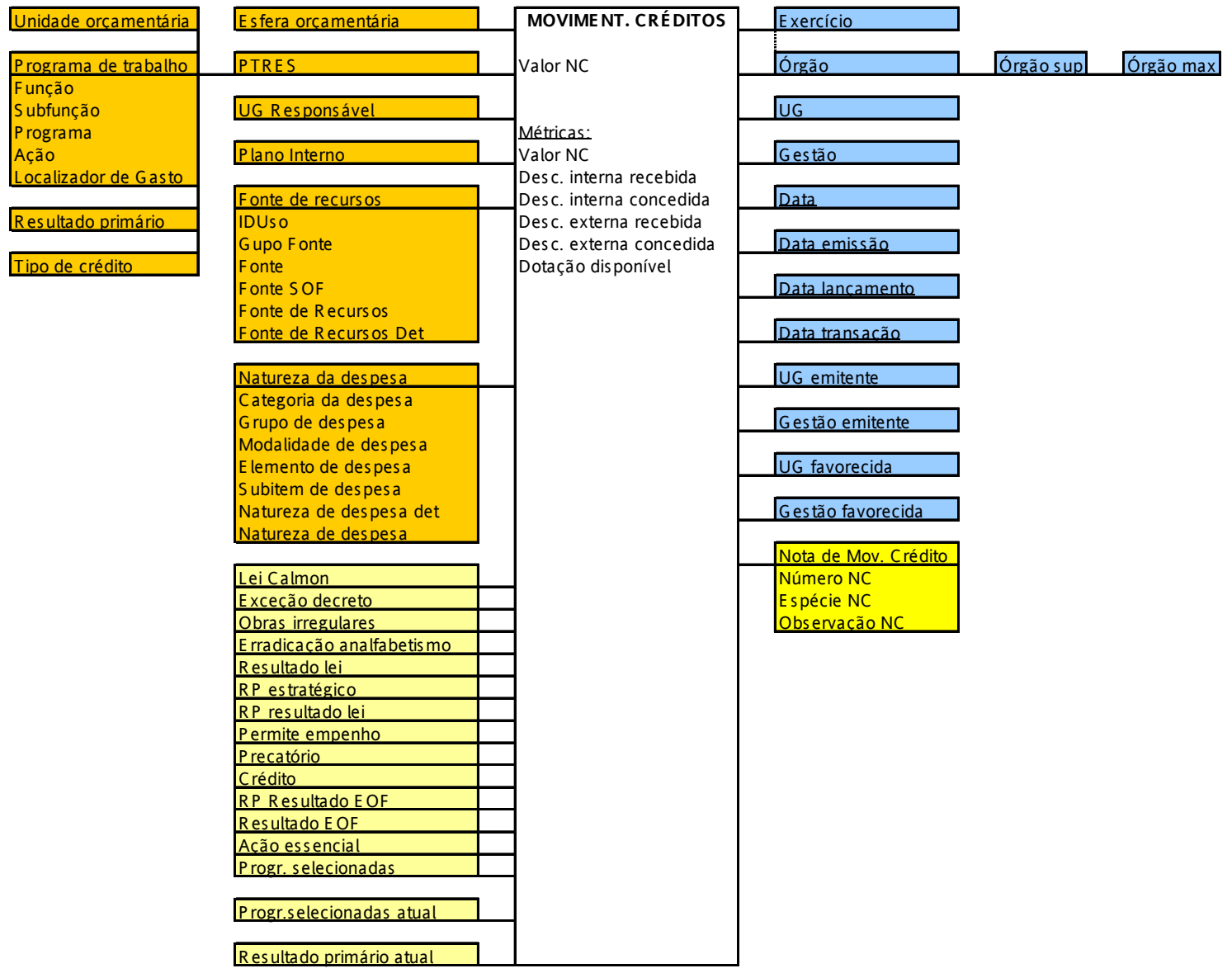




\begin{tabular}{|c|c|c|c|c|c|}
\hline Unidade orçamentária & Esfera orçamentária & EMPENHO & Exercício & & \\
\hline Programa de trabalho & PTRES & Valor NE & Órgão & Orgão sup & Orgão max \\
\hline Função & & & & & \\
\hline Subfunção & UG Responsável & & $\overline{U G}$ & & \\
\hline $\begin{array}{l}\text { Programa } \\
\text { Acão }\end{array}$ & Plano Interno & Métricas: & Gestão & & \\
\hline Localizador de Gasto & & $\overline{\text { Valor NE }}$ & & & \\
\hline & Fonte de recursos & Empenhado original & Favorecido & & \\
\hline Resultado primário & $\longdiv { I D U s o }$ & Reforço de empenho & & & \\
\hline & Gupo Fonte & Anulação de empenho & Data & & \\
\hline Tipo de crédito & Fonte & Cancelamento de empenho & & & \\
\hline & Fonte SOF & Estorno de canc/anulação de empenho & Data emissão & & \\
\hline & Fonte de Recursos Det & J Valor empenhado & Data lançamento & & \\
\hline & $\sqrt{\text { Natureza da despesa }}$ & Valor RP inscrito & $\sqrt{\text { Data transacão }}$ & & \\
\hline & Categoria da despesa & Valor RP inscrito não processado & & & \\
\hline & Grupo de despesa & Valor RP cancelado & UG emitente & & \\
\hline & $\begin{array}{l}\text { Modalidade de despesa } \\
\text { Elemento de despesa } \\
\text { Sunitem }\end{array}$ & Valor RP inscrito liquido & Gestão emitente & & \\
\hline & & & Empenho Referência & Empenho & \\
\hline & Lei Calmon & & Número NE Ref & Número NE & \\
\hline & Exceção decreto & & Espécie NE & Observação NE & \\
\hline & Obras irregulares & & Observação NE Ref & Tipo NE & \\
\hline & Erradicação analfabetismo & & & Modalidade NE & \\
\hline & Resultado lei & & & Amparo Legal NE & \\
\hline & RP estratégico & & & & \\
\hline & RP resultado lei & & Indicador RP & & \\
\hline & Permite empenho & & & & \\
\hline & Precatório & & & & \\
\hline & Crédito & & & & \\
\hline & RP Resultado EOF & & & & \\
\hline & Resultado EOF & & & & \\
\hline & Ação essencial & & & & \\
\hline & Progr. selecionadas & & & & \\
\hline & Progr.selecionadas atual & & & & \\
\hline & Resultado primário atual & & & & \\
\hline
\end{tabular}




\begin{tabular}{|c|c|c|c|c|c|}
\hline Unidade orçamentária & Esfera orçamentária & ITENS DE EMPENHO & Exercício & & \\
\hline \multirow{4}{*}{\begin{tabular}{|l|} 
Programa de trabalho \\
Funcáo \\
Subfunção \\
Programa \\
Ação \\
Localizador de G as to \\
\end{tabular}} & \multirow{8}{*}{$\begin{array}{l}\text { PTRES } \\
\text { UG Res ponsável } \\
\text { Plano Interno } \\
\text { Fonte de recurs os } \\
\text { IDUso } \\
\text { Gupo Fonte } \\
\text { Fonte } \\
\text { Fonte SOF } \\
\text { Fonte de Recursos } \\
\text { Fonte de Recurs os Det } \\
\end{array}$} & \multirow{5}{*}{$\begin{array}{l}\text { Valor item NE } \\
\text { Qtde itens NE } \\
\text { Métricas: } \\
\text { Valor item NE } \\
\text { Quantidade de itens de NE }\end{array}$} & Órgão & Órgão sup & \multirow[t]{4}{*}{ Ó́rgão max } \\
\hline & & & $\longdiv { U G }$ & & \\
\hline & & & Gestão & & \\
\hline & & & & & \\
\hline Resultado primário & & & IFavorecido & & \\
\hline \multirow{21}{*}{ Tipo de crédito } & & & Data & & \\
\hline & & & Data emissão & & \\
\hline & & & Datalancamente & & \\
\hline & \multirow{4}{*}{\begin{tabular}{|l|} 
Natureza da des pesa \\
Categoria da despesa \\
G rupo de des pesa \\
Modalidade de despesa \\
Elemento de despesa \\
Subitem de despesa \\
Natureza de despesa det \\
Natureza de despesa \\
\end{tabular}} & & Data trans acão & & \\
\hline & & & UG emitente & & \\
\hline & & & Gestão emitente & & \\
\hline & & & \multirow{15}{*}{\begin{tabular}{|l|} 
Lista de itens de empenho \\
Sequencial do Item NE \\
Número Lista de Itens NE \\
Observacãa ltem NEE \\
\end{tabular}} & \multirow{15}{*}{\begin{tabular}{|l|} 
Empenho Referência \\
Número NE Ref \\
Espécie NE \\
Observacăo NE Ref \\
\end{tabular}} & \multirow{15}{*}{\begin{tabular}{|l|} 
Empenho \\
Número NE \\
Observação NE \\
Tipo NE \\
Modalidade NE \\
Amparo Legal NE \\
\end{tabular}} \\
\hline & & & & & \\
\hline & Excecăo decreto & & & & \\
\hline & \begin{tabular}{|l} 
Obras irregulares \\
\end{tabular} & & & & \\
\hline & $\begin{array}{l}\text { Erradicacão analfabetis mo } \\
\text { Resultado lei }\end{array}$ & & & & \\
\hline & \begin{tabular}{|l|l|l|l} 
RP estratégico \\
\end{tabular} & & & & \\
\hline & RP resultado lei & & & & \\
\hline & \begin{tabular}{|l} 
Permite empenhoo \\
Precatório
\end{tabular} & & & & \\
\hline & Crédito & & & & \\
\hline & RP Resultado EOF & & & & \\
\hline & Resultado EOF & & & & \\
\hline & $\begin{array}{l}\text { Acao essenclal } \\
\text { Progr. selecionadas } \\
\end{array}$ & & & & \\
\hline & Progrselecionadas atual & & & & \\
\hline & & & & & \\
\hline & Resultado primário atual & & & & \\
\hline
\end{tabular}




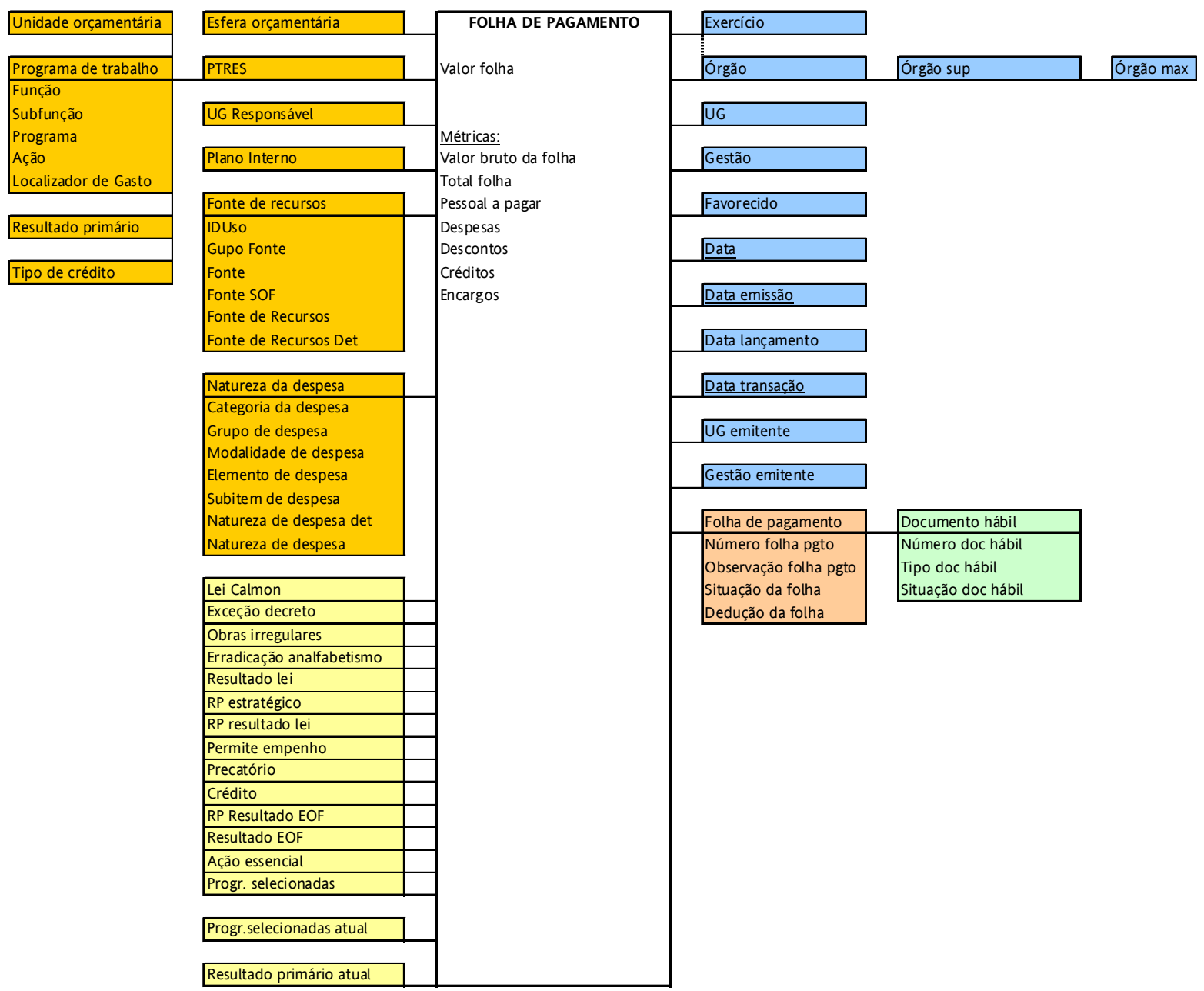




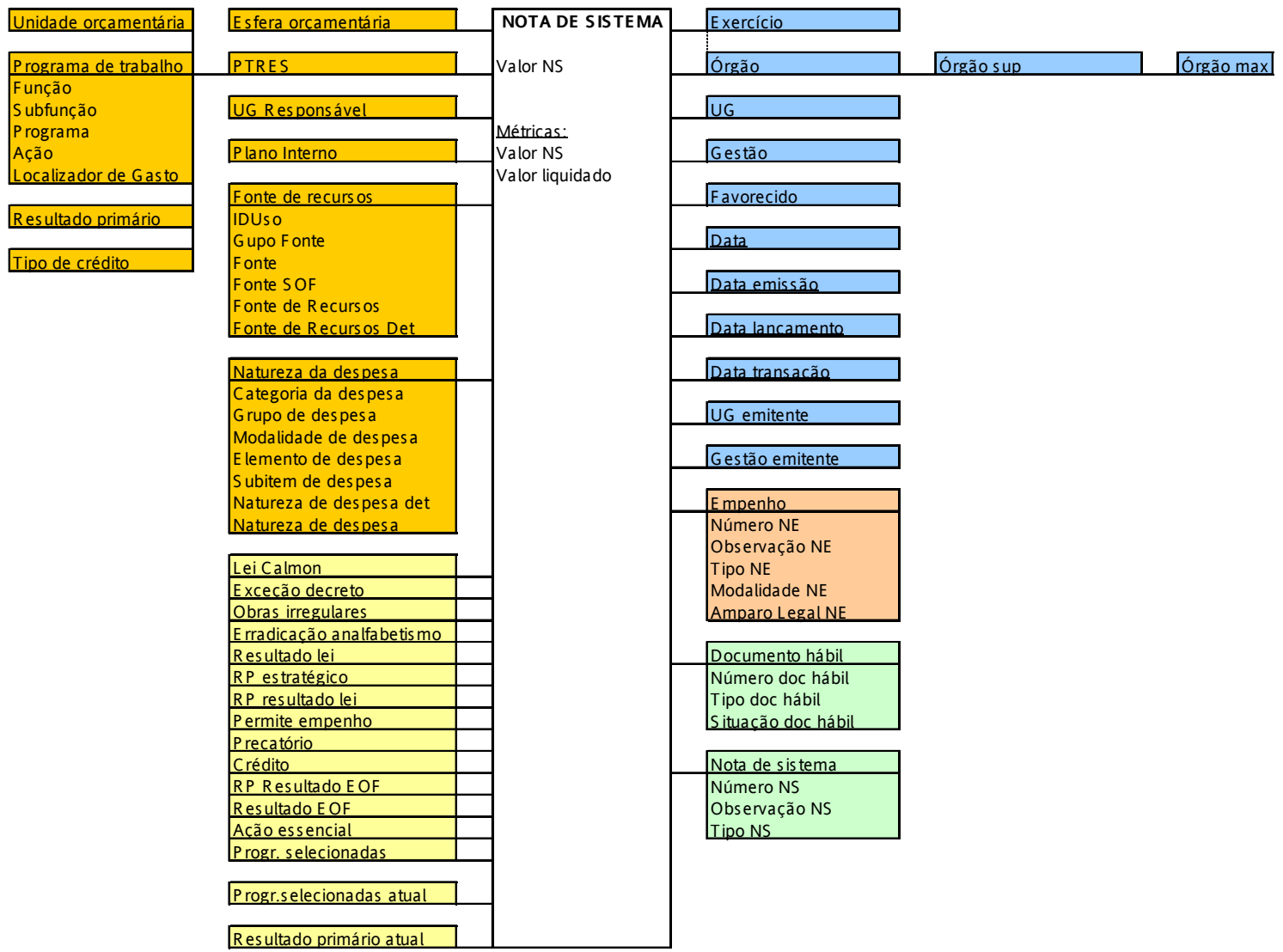




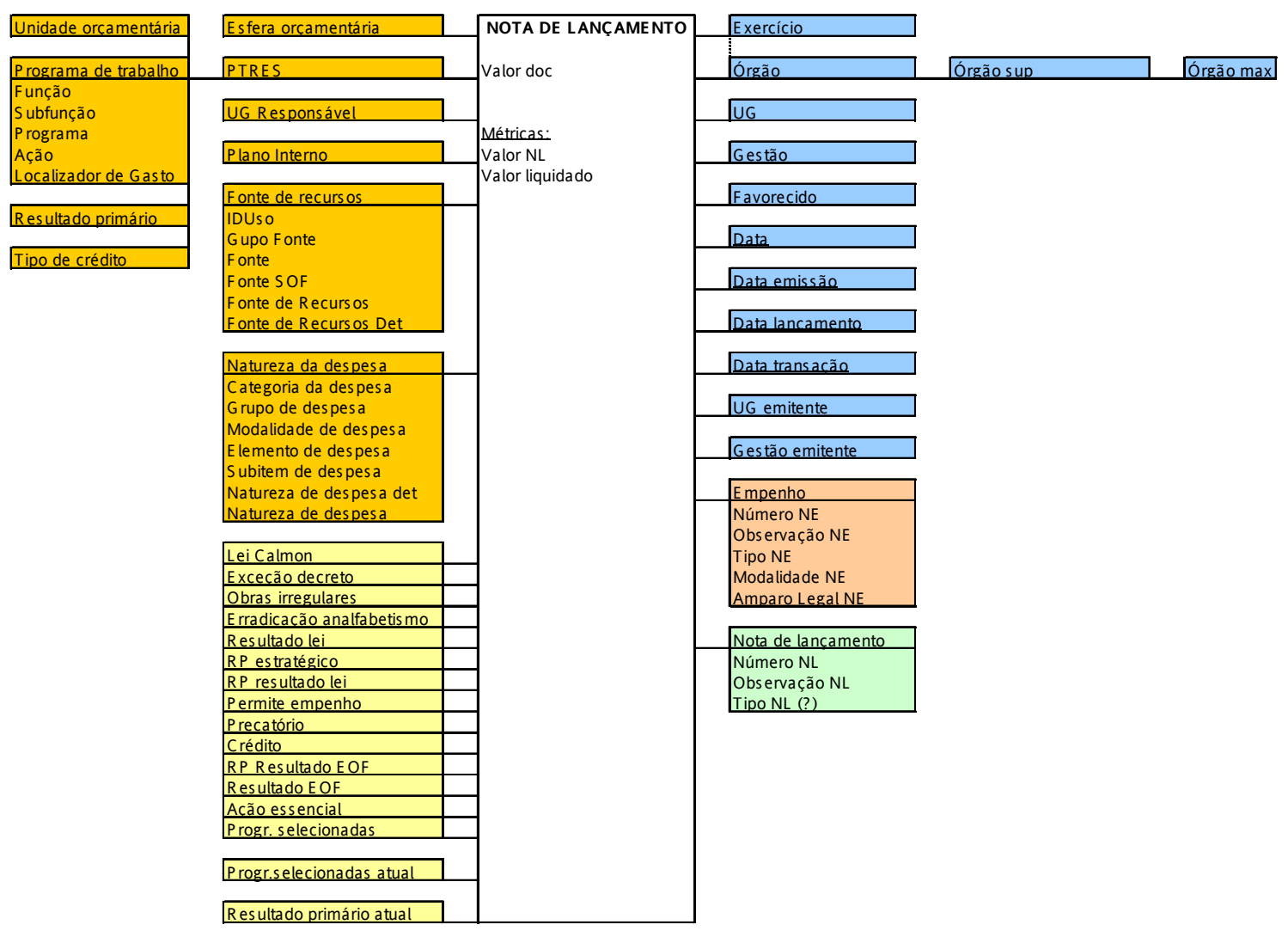




\begin{tabular}{|c|c|c|c|c|c|}
\hline Unidade orçamentária & Esfera orçamentária & \multirow{3}{*}{\begin{tabular}{|l|}
\multicolumn{2}{|c|}{ PAGAMENTO } \\
Valor pagamento \\
Ind enfoque
\end{tabular}} & Exercício & & \\
\hline \multirow{6}{*}{\begin{tabular}{|l|} 
Programa de trabaltho \\
Função \\
Subfunção \\
Programa \\
Ação \\
Localizador de Gasto \\
\end{tabular}} & PTRES & & Órgão & Órgão sup & Órgão max \\
\hline & UG Responsável & & UG & & \\
\hline & 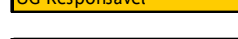 & \multirow{10}{*}{\begin{tabular}{|l} 
Métricas: \\
Valor pagamento \\
Valor pago \\
Possui dado financeiro \\
Possui dado orçamentário \\
Financeiro \\
Orçamentário \\
Valor pago (financeiro) \\
Valor pago (orçamentário) \\
Valor a pagar \\
Valor R pago \\
Valor RP a pagar
\end{tabular}} & & & \\
\hline & Plano Interno & & Gestão & & \multirow{5}{*}{\begin{tabular}{|l|} 
AARF \\
Contribuinte DARF \\
Recursos DARF \\
Processo DARF \\
Receita DARF \\
Base de cálculo \\
\end{tabular}} \\
\hline & & & & & \\
\hline & Fonte de recursos & & Favorecido & & \\
\hline \multirow{2}{*}{ Resultado primário } & DUSo & & & & \\
\hline & Gupo Fonte & & Data & & \\
\hline \multirow[t]{34}{*}{ Tipo de crédito } & $\begin{array}{l}\text { Fonte } \\
\text { Fonte SOF }\end{array}$ & & Data emissão & & \\
\hline & Fonte de Recursos & & & & \multirow{7}{*}{\begin{tabular}{|l} 
DAR \\
UG Arrecadadora DAR \\
Munic. Favorec. DAR \\
Recolhedor DAR \\
Recurso DAR \\
Receita DAR \\
Info Recolh. DAR \\
Alíquota da NF \\
Valor NF \\
\end{tabular}} \\
\hline & Fonte de Recursos Det & & Data lançamento & & \\
\hline & Natureza da despesa & & Data transacão & & \\
\hline & Categoria da despesa & & IDdda IIdisaldad & & \\
\hline & Grupo de despesa & & $\sqrt{U G \text { emitente }}$ & & \\
\hline & Modalidade de despesa & & & & \\
\hline & $\begin{array}{l}\text { Elemento de despesa } \\
\text { Subitem de despesa }\end{array}$ & & Gestão emitente & & \\
\hline & Natureza de despesa det & & Documento hábil & & \\
\hline & Natureza de despesa & & Número doc hábil & & \multirow{6}{*}{\begin{tabular}{|l|} 
GRU \\
UG/Gestão Fav. GRU \\
Recolhedor GRU \\
Cod. Recolh. GRU \\
Recurso GRU \\
Num Ref GRU
\end{tabular}} \\
\hline & & & Tipo doc hábil & & \\
\hline & Lei Calmon & & Situação doc hábil & & \\
\hline & Exceção decreto & & & & \\
\hline & Obras irregulares & & Empenho & & \\
\hline & Erradicação analfabetismo & & \multirow{5}{*}{$\begin{array}{l}\text { IvUmero INE } \\
\text { Observação NE } \\
\text { Tipo NE } \\
\text { Modalidade NE } \\
\text { Amparo Legal NE } \\
\end{array}$} & & \\
\hline & Resultado lei & & & & \multirow{9}{*}{\begin{tabular}{|l|} 
Ordem Bancária \\
Tipo OB \\
Banco Fav OB \\
Agência Fav OB \\
CC Fav OB \\
Num Bancário \\
Processo OB \\
Ident. Transf. OB \\
\end{tabular}} \\
\hline & RP estratégico & & & & \\
\hline & RP resultado lei & & & & \\
\hline & Permite empenho & & & & \\
\hline & Precatório & & & & \\
\hline & Crédito & & & & \\
\hline & RP Resultado EOF & & & & \\
\hline & Resultado EOF & & \multirow{4}{*}{\begin{tabular}{|l|} 
Liquidação \\
Número doc liquidação \\
Observação liquidação \\
Tipo doc liquidação \\
\end{tabular}} & & \\
\hline & Ação essencial & & & \multirow{5}{*}{ Pagamento } & \\
\hline & Progr. selecionadas & & & & \\
\hline & & & & & \multirow{2}{*}{\begin{tabular}{|l|} 
GPS \\
Recolhedor GPS
\end{tabular}} \\
\hline & \begin{tabular}{|l} 
Progr.selecionadas atual \\
\end{tabular} & & \multirow{8}{*}{\begin{tabular}{|l|} 
Pagamento Ref \\
Número pgto ref \\
Tipo pgto ref \\
Espécie pgto \\
Observação pgto ref
\end{tabular}} & & \\
\hline & & & & & \multirow{4}{*}{\begin{tabular}{|l} 
Recolhedor GPS \\
Cód Pgto GPS \\
Competência GPS \\
Recurso GPS \\
Processo GPS \\
\end{tabular}} \\
\hline & Resultado primário atual & & & \multirow{6}{*}{\begin{tabular}{|l|}
$\begin{array}{l}\text { Número pgto } \\
\text { Tipo pgto } \\
\text { Observaçãão pgto }\end{array}$ \\
\end{tabular}} & \\
\hline & Vincutacz̃o de ngto & & & & \\
\hline & & & & & \\
\hline & Categoria de gasto & & & & GFIP \\
\hline & & & & & Recolhimento GFIP \\
\hline & Tipo empenho pgto & & & & \\
\hline
\end{tabular}




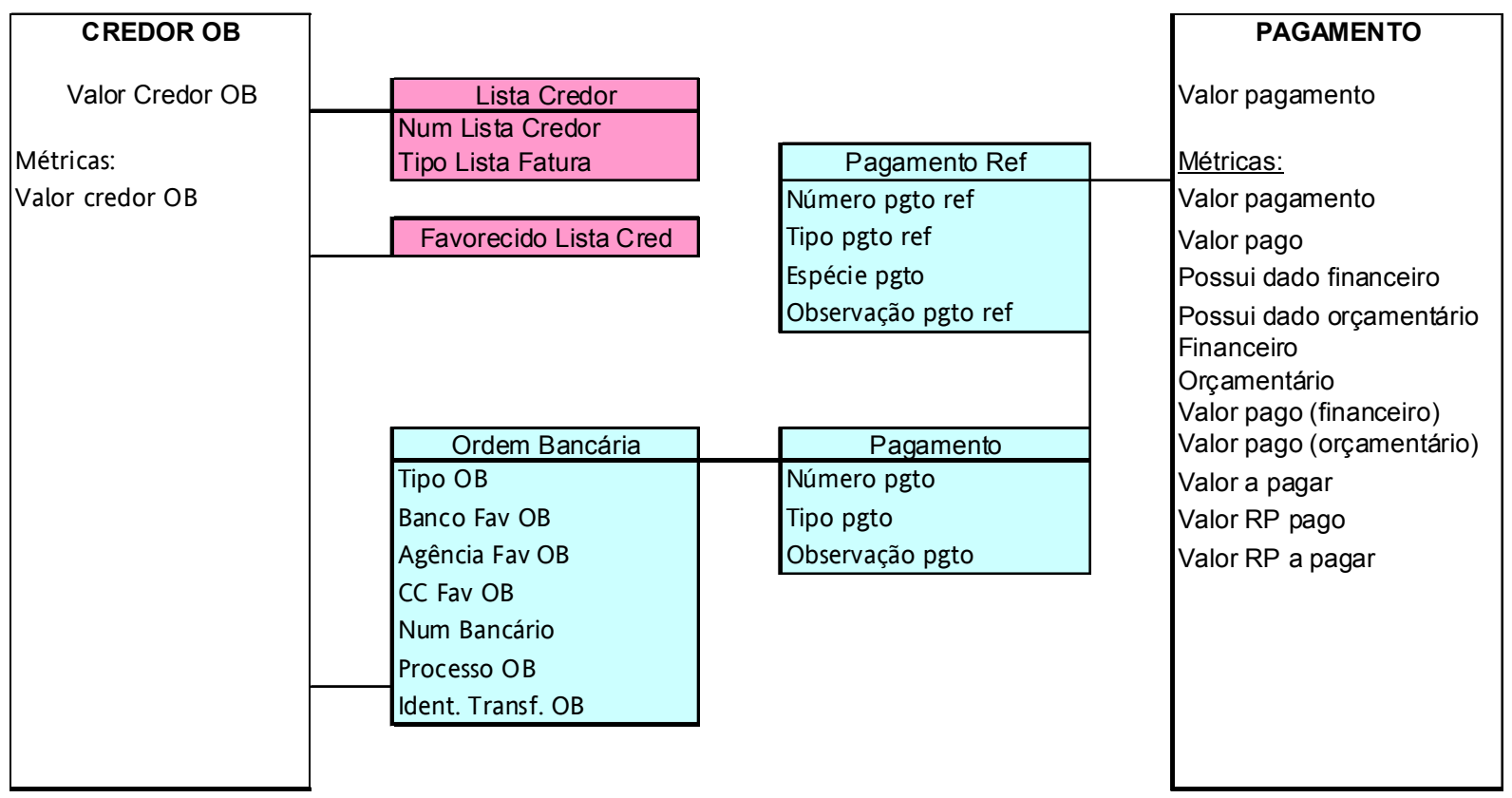




\section{APÊNDICE B - MODELO DIMENSIONAL - DESCRIÇÃO DAS MÉTRICAS}

\begin{tabular}{|c|c|}
\hline Dotação & \\
\hline Valor ND & Soma (Valor ND) \\
\hline Dotação inicial & Soma (Valor ND) se Espécie ND = Inicial \\
\hline Créditos suplementares & Soma (Valor ND) se Espécie ND = Suplementar \\
\hline Créditos especiais & Soma (Valor ND) se Espécie ND = Especial \\
\hline Créditos extraordinários & Soma (Valor ND) se Espécie ND = Extraordinário \\
\hline Créditos cancelados & Soma (Valor ND) se Espécie ND = Cancelado \\
\hline Créditos reabertos - esp & Soma (Valor ND) se Espécie ND = Especial Reaberto \\
\hline Créditos reabertos - extra & Soma (Valor ND) se Espécie ND = Extra reaberto \\
\hline Crédito bloqueado & Soma (Valor ND) se Espécie ND = Bloqueio \\
\hline Contingenciamento & Soma (Valor ND) se Espécie ND = Contingenciamento \\
\hline Lei + Créditos & $\begin{array}{l}\text { Dotação inicial + Créditos suplementares }+ \text { Créditos especiais }+ \\
\text { Créditos extraordinários }+ \text { Créditos cancelados }+ \text { Créditos especiais } \\
\text { reabertos }+ \text { Créditos extra reabertos }\end{array}$ \\
\hline
\end{tabular}

\begin{tabular}{|c|c|}
\hline Movimentação de Créditos & \\
\hline Valor NC & Soma (Valor NC) \\
\hline Desc. interna recebida & Soma (Valor NC) se Espécie NC = Interna Recebida \\
\hline Desc. interna concedida & Soma (Valor NC) se Espécie NC = Interna Concedida \\
\hline Desc. externa recebida & Soma (Valor NC) se Espécie NC = Externa Recebida \\
\hline Desc. externa concedida & Soma (Valor NC) se Espécie NC = Externa Concedida \\
\hline Dotação disponível & $\begin{array}{l}\text { Lei + Créditos - Contingenciamento - Crédito bloqueado + Desc.interna } \\
\text { recebida - Desc.interna concedida + Desc. externa recebida - Desc. } \\
\text { externa concedida }\end{array}$ \\
\hline
\end{tabular}




\begin{tabular}{|c|c|}
\hline Empenho & \\
\hline Valor NE & Soma (Valor NE) \\
\hline Empenhado original & Soma (Valor NE) se Espécie NE = Empenho de despesa e Ind RP = Não RP \\
\hline Reforço de empenho & Soma (Valor NE) se Espécie NE = Reforço e Ind RP = Não RP \\
\hline Anulação de empenho & Soma (Valor NE) se Espécie NE = Anulação e Ind RP = Não RP \\
\hline Cancelamento de empenho & Soma (Valor NE) se Espécie NE = Cancelamento e Ind RP = Não RP \\
\hline $\begin{array}{l}\text { Estorno de canc/anulação } \\
\text { de empenho }\end{array}$ & Soma (Valor NE) se Espécie NE = Estorno e Ind RP = Não RP \\
\hline Valor empenhado & $\begin{array}{l}\text { Empenhado original + Reforço de empenho + Anulação de empenho + } \\
\text { Cancelamento de empenho }+ \text { Estorno de canc/anulação de empenho }\end{array}$ \\
\hline Valor RP inscrito & Valor RP inscrito processado + Valor RP inscrito não processado \\
\hline $\begin{array}{l}\text { Valor RP inscrito } \\
\text { processado }\end{array}$ & Soma (Valor NE) se Ind RP $=$ Processado \\
\hline $\begin{array}{l}\text { Valor RP inscrito não } \\
\text { processado }\end{array}$ & Soma (Valor NE) se Ind RP = Não processado \\
\hline Valor RP cancelado & Soma (Valor NE) se Ind RP = Cancelado \\
\hline Valor RP inscrito líquido & Valor RP inscrito - Valor RP cancelado \\
\hline
\end{tabular}

\begin{tabular}{|c|c|}
\hline Itens de empenho & \\
\hline Valor item NE & Soma (Valor item NE) \\
\hline Quantidade de itens de NE & Soma (Qtde itens NE) \\
\hline
\end{tabular}

\begin{tabular}{|c|c|}
\hline Folha de pagamento & \\
\hline Valor bruto da folha & Soma (Valor Folha) \\
\hline Total folha & Pessoal a Pagar + Encargos \\
\hline Pessoal a pagar & Despesas + Créditos - Descontos \\
\hline Despesas & $\begin{array}{l}\text { Soma (Valor Folha) se Situação da Folha } \neq \text { Nulo e se Situação da Folha } \\
\text { diferente de U20,U21,U22 e U90 }\end{array}$ \\
\hline Descontos & Soma (Valor Folha) se Situação da Folha $\neq$ Nulo e Dedução da Folha $\neq$ Nulo \\
\hline Créditos & Soma (Valor Folha) se Situação da Folha = Nulo e Dedução da Folha = Nulo \\
\hline Encargos & Soma (Valor Folha) se Situação da Folha $=$ Nulo e Dedução da Folha $\neq$ Nulo \\
\hline
\end{tabular}




\begin{tabular}{|l|l|}
\hline Nota de Sistema & \\
\hline Valor NS & Soma (Valor NS) \\
\hline
\end{tabular}

\begin{tabular}{|l|l|}
\hline Nota de Lançamento & \multicolumn{1}{|l}{} \\
\hline Valor NL & Soma (Valor NL) \\
\hline Valor liquidado & Valor NS + Valor NL \\
\hline
\end{tabular}

\begin{tabular}{|c|c|}
\hline Pagamento & \\
\hline Valor pagamento & Soma (Valor pagamento) \\
\hline Valor pago $^{15}$ & Soma (Valor pagamento*Ind Espécie) \\
\hline Possui dado financeiro & Soma (Valor pagamento*Ind Espécie) se Ind enfoque $=$ CFIN ou COF \\
\hline Possui dado orçamentário & Soma (Valor pagamento*Ind Espécie) se Ind enfoque $=$ CORC \\
\hline Financeiro & $\begin{array}{l}\text { Soma (Valor pagamento*Ind Espécie) se Ind enfoque }=\text { CFIN ou SFIN ou } \\
\text { SORC ou COF }\end{array}$ \\
\hline Orçamentário & $\begin{array}{l}\text { Soma (Valor pagamento*Ind Espécie) se Ind enfoque }=\text { CORC ou SFIN ou } \\
\text { SORC ou COF }\end{array}$ \\
\hline Valor pago (financeiro) & Se Possui dado financeiro = nulo então Orçamentário senão Financeiro \\
\hline $\begin{array}{l}\text { Valor pago } \\
\text { (orçamentário) }\end{array}$ & Se Possui dado orçamentário = nulo então Financeiro senão Orçamentário \\
\hline Valor a pagar & Valor Liquidado - Valor Pago \\
\hline Valor RP pago & Soma (Valor pagamento*Ind Espécie) se Indicador RP $=\mathrm{RP}$ \\
\hline Valor RP a pagar & Valor RP inscrito líquido - Valor RP pago \\
\hline
\end{tabular}

\begin{tabular}{|l|l|}
\hline Credor OB & \\
\hline Valor credor OB & Soma (Valor credor OB) \\
\hline
\end{tabular}

\footnotetext{
${ }^{15}$ Métrica válida somente se implantada a sugestão de criação de uma conta contábil de controle para registro das informações orçamentárias e financeiras.
} 


\section{ANEXO A - MODELAGEM DIMENSIONAL EM NÍVEIS Um Modelo de Arquitetura de Informações para Sistemas Gerenciais \\ Autora: Rosângela Gomes da Nóbrega}

O modelo dimensional de dados é peça fundamental do processo de implementação de um sistema DW. Na prática, o modelo dimensional tem sido criado diretamente com suas características físicas, já antecipando as estruturas a serem implementadas no banco de dados relacional.

A Modelagem Dimensional em Níveis é uma idéia inovadora. Ela foi se delineando no decorrer de diversas experiências de modelagem dimensional, pela identificação de padrões de comportamento dos dados que se revelavam constantes, independentemente do assunto tratado.

\section{$\underline{\text { As Variáveis do Sistema DW }}$}

Um sistema DW oferece ao Usuário variáveis com as quais ele próprio projetará seus relatórios. Tais variáveis são de dois tipos: variáveis dependentes, conhecidas como métricas, e variáveis independentes, conhecidas como dimensões.

O primeiro passo da construção do modelo dimensional é a identificação das variáveis. O resultado desse passo é a lista de todas as variáveis que comporão o sistema, contendo o nome, sua caracterização como dimensão ou métrica e a definição de cada uma delas, semelhante às definições encontradas em um dicionário.

\section{Modelo Dimensional de Dados}

O modelo dimensional de dados (MD), é um modelo que captura a semântica do negócio, reproduzindo-a na linguagem de comunicação entre o Usuário e o sistema informatizado.

Um modelo dimensional corretamente construído apresentará necessariamente como característica mais marcante a compreensibilidade pelo Usuário do sistema DW.

Como dito anteriormente, as variáveis que compõem o MD classificam-se em métricas e dimensões. Métricas e dimensões formam estruturas no formato radial, com as métricas no centro e as dimensões ao seu redor. Devido à sua forma radial, essas estruturas são chamadas de estrelas. 
Sem uma arquitetura adequada para organizar o conhecimento representado por tantas estrelas, os sistemas DW correm o risco de se tornar misteriosos ajuntamentos de dados, o que tende a se complicar ainda mais com as freqüentes evoluções que são comuns em sistemas gerenciais, podendo comprometer seriamente a navegabilidade do sistema.

A Modelagem Dimensional em Níveis para DW cria uma metodologia para a construção de modelos dimensionais que resulta no desenho de uma "constelação" interligando as diversas estrelas do DW.

Com a Modelagem Dimensional em Níveis é possível sistematizar a elaboração do modelo dimensional, tornando esse processo mais previsível (menos mágico!) e mais acessível às pessoas envolvidas nos sistemas DW.

\section{Métricas, Dimensões, Estrelas e Granularidade}

O que, do ponto de vista da informática, seriam colunas de tabelas, do ponto de vista do negócio são as variáveis de interesse. No modelo dimensional de dados, as variáveis de interesse podem ser dependentes ou independentes. As variáveis dependentes recebem o nome de métricas e as variáveis independentes recebem o nome de dimensões. Em geral, uma consulta ao sistema DW visa a descobrir os valores que as variáveis dependentes (métricas) assumem para cada combinação possível das variáveis independentes (dimensões).

As métricas são medições numéricas do negócio, correspondendo a valores monetários ou quantidades. Métricas bem comportadas são numéricas, continuamente valoradas e aditivas, isto é, sua soma é um valor que faz sentido. As métricas são o foco da curiosidade do Usuário. As dimensões formam o contexto em que o valor da métrica acontece, constituindo os parâmetros de pesquisa disponíveis para o Usuário.

É interessante distinguir dois tipos de dimensões: as dimensões individuais e as dimensões coletivas.

$\mathrm{Na}$ dimensão individual, cada elemento representa um único objeto do mundo real, seja ele um elemento concreto ou um elemento abstrato (tipificações). São exemplos de dimensão individual: cliente, data, localidade, regime tributário, via de transporte, apólices de seguro, sexo, declaração de importação, nota fiscal.

$\mathrm{Na}$ dimensão coletiva, cada elemento representa um conjunto de objetos do mundo real que, para efeito do modelo, são exatamente iguais. São dimensões coletivas: mercadoria, produto, serviço, vôo. 
O trabalho inicial de levantamento de requisitos para o sistema gerencial de informações consiste em elaborar a lista de métricas e, para cada métrica, a lista das dimensões que compõem seu contexto, ou seja, que estão radialmente dispostas ao redor da métrica.

À medida que as métricas vão sendo identificadas, é preciso decidir quais métricas ficarão juntas na mesma estrela e, conseqüentemente, quantas estrelas comporão o modelo.

A granularidade é a principal característica de uma métrica e corresponde ao nível de maior detalhamento no qual essa métrica existe no sistema DW.

É em função da granularidade que surge a necessidade de se ter diversas estrelas em um modelo dimensional, pois é terminantemente vetada a convivência, na mesma estrela, de métricas com granularidades distintas.

\section{Construção do Modelo Dimensional}

Há dois caminhos que levam ao modelo dimensional, um deles é o levantamento de necessidades de informações do Usuário, o outro é o levantamento minucioso da documentação dos sistemas fonte, isto é, dos sistemas de origem das informações a serem trazidas para o DW.

Qual caminho seguir? É preciso seguir os dois simultaneamente, seguir um pouco pelo primeiro caminho, para conhecer as necessidades de informações gerenciais do Usuário, em seguida seguir um pouco pelo segundo caminho, para conhecer a matéria-prima existente para construir tais informações e assim por diante.

É provável que se chegue a um conjunto de várias estrelas.

À primeira vista essas estrelas podem parecer completamente independentes entre si. No entanto, de acordo com as necessidades de informações para apoiar o processo decisório, certamente o Usuário desejará fazer consultas que apresentem, lado-a-lado, métricas de duas ou mais dessas estrelas.

Para que isso seja possível, é necessário que haja dimensões comuns a várias estrelas, pois essas serão as dimensões permitidas nas consultas simultâneas a várias estrelas.

O Barramento de Dimensões é uma proposta de organização do modelo dimensional elaborada por Ralph Kimball que visa a estabelecer as condições para a elaboração das consultas que abrangem várias estrelas do modelo dimensional. O Barramento representou uma evolução importante na modelagem dimensional, pois criou a integrabilidade 
(possibilidade de integração) entre as diversas estrelas de um DW, constituindo um princípio de abordagem arquitetônica do modelo dimensional.

Enquanto que o Barramento de Dimensões dispõe todas as estrelas em um único arranjo horizontal, igualmente conectadas às dimensões comuns, a Modelagem Dimensional em Níveis dispõe as estrelas em diversos arranjos verticais, em que a estrela de baixo, além de possuir dimensões específicas, herda todas as dimensões da estrela de cima.

\section{Modelagem Dimensional em Níveis}

A Modelagem Dimensional em Níveis revela um padrão de enriquecimento sucessivo de detalhes, permitindo identificar com precisão as dimensões a serem transmitidas por herança de uma estrela para outra.

As constelações criadas pela Modelagem Dimensional em Níveis evidenciam a relação intrínseca existente entre as estrelas no mundo do negócio que elas representam. Por exemplo, se tivermos uma estrela "Nota Fiscal" e uma outra estrela "Item da Nota Fiscal", veremos que essas duas estrelas formam uma constelação bastante simples, em dois níveis, para a qual é construído o seguinte diagrama:

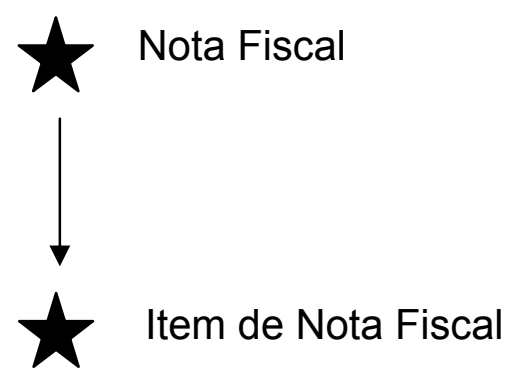

"Quantidade de Notas Fiscais" é uma métrica nativa da estrela "Nota Fiscal”. Por outro lado, "Valor do Item", "Valor Unitário do Item", "Quantidade de Itens", “Quantidade Vendida no Item" são quatro métricas nativas da estrela "Item de Nota Fiscal".

A seta indica que todas as dimensões da estrela Nota Fiscal (como Número da Nota Fiscal e Data da Venda) são herdadas pela estrela Item de Nota Fiscal.

Ao criar as constelações, a Modelagem Dimensional em Níveis fornece aos indivíduos envolvidos com o sistema DW uma visão panorâmica da "floresta de informações" associada ao negócio, como uma operação de “zoom out” em relação às dezenas de estrelas que compõem o modelo. 